\title{
Catalytic Activation of Bioorthogonal Chemistry with Light (CABL) Enables Rapid, Spatiotemporially-controlled Labeling and No-Wash, Subcellular 3D-Patterning in Live Cells using Long Wavelength Light
}

Andrew Jemas, ${ }^{1}$ Yixin Xie, ${ }^{1}$ Jessica E. Pigga, ${ }^{1}$ Jeffrey L. Caplan, ${ }^{2}$ Christopher W. am Ende, ${ }^{3}$ Joseph M. Fox ${ }^{1}$

${ }^{1}$ Department of Chemistry and Biochemistry, University of Delaware, Newark, Delaware 19716, USA

${ }^{2}$ Department of Plant and Soil Sciences and Delaware Biotechnology Institute, University of Delaware, Newark, DE 19716, USA

${ }^{3}$ Pfizer Worldwide Research and Development, Eastern Point Road, Groton, Connecticut 06340, United States

Table of Contents

1: Synthetic Procedures

2: In Vitro DHTz Stability And Photooxidation Kinetics

3: Plasmids

4: HaloTag Conjugation and Photoactivation

5: Photoactivation of DHTz-HaloTag in e. coli

6: Photoactivation of DHTz-HaloTag in HeLa Cells

7: Photoactivation of DHTz-MAGL in PC3 Cells

8: MTT Assay

9: NMR Spectra 


\subsection{General Considerations}

All reactions were conducted in flame dried round-bottom flasks. All reactions using microwave heating were conducted in $5 \mathrm{~mL}$ microwave reaction tubes. All optimization reactions were conducted in $4 \mathrm{~mL}$ sealed vials. Silica gel chromatography was performed on Silicycle Siliaflash irregular P60 silica gel $(40-63 \mu \mathrm{m}, 60 \AA)$ or on Yamazen reverse phase prepacked Universal Column C18-silica gel (40-60 $\mu \mathrm{m}, 120 \AA)$. Automated column chromatography was performed on a Teledyne Isco Combiflash Rf. Commercially available chemicals were purchased from Sigma-Aldrich, Combi-Blocks, Acros Organics, Alfa Aesar and TCI Chemicals. Solvents were purchased from Thermo Fisher Chemical, Acros Organics and Millipore Sigma. Anhydrous dichloromethane was freshly prepared by an alumina column solvent purification system. Anhydrous tetrahydrofuran was freshly distilled from sodium/benzophenone. Deuterated solvents were purchased from Cambridge Isotope. A Bruker AV400 was used to record NMR spectra $\left({ }^{1} \mathrm{H}: 400 \mathrm{MHz},{ }^{13} \mathrm{C}: 101 \mathrm{MHz}\right)$. Chemical shifts are reported in ppm. Multiplicities are reported as follow: singlet (s), doublet (d), triplet (t), quartet (q), pentet (pent), sextet (sext), heptet (hept), multiplet (m), 'broad' (br), and 'apparent' (app). ${ }^{13} \mathrm{C}$ NMR resonances are proton decoupled and an APT pulse sequence was used to determine type of carbon as follows: quaternary and methylene $\left(\mathrm{C}\right.$ or $\left.\mathrm{CH}_{2}\right)$ carbons appear 'up' and methine and methyl $\left(\mathrm{CH}\right.$ or $\left.\mathrm{CH}_{3}\right)$ carbons appear 'down'. High resolution mass spectra were obtained using a Waters GCT Premier and Thermo Q-Exactive Orbitrap. Stopped-flow kinetics were obtained using an Applied Photophysics Ltd. SX 18MV-R stopped-flow spectrophotometer. UV-Vis measurements were conducted in quartz cuvettes using a Hewlett Packard 8453 spectrophotometer at $25{ }^{\circ} \mathrm{C}$. Photochemical experiments with UV-vis monitoring were carried out in a UV-cuvette holder with stirring capability and a top mounted, high power LED source. The LED was either a 'deep red' Cree XLamp XP-E “3 up” High Power LED Star (CREEXPE-DRD-3; $660 \mathrm{~nm}$ ) or a 'blue’ Cree XLamp XP-E “3 up” High Power LED Star (CREEXPE2-BLU-3, $470 \mathrm{~nm}$ ) and purchased from LED Supply

(https://www.ledsupply.com/leds/cree-xlamp-xpe-high-power-led-star). The LED was mounted 
on a heat sink with a driver used is $\mathrm{P} / \mathrm{N}$ 03023-D-E-1000P and is found here : https://www.ledsupply.com/led-drivers/buckpuck-dc-led-drivers. For UV-vis experiments, the light intensity was estimated by measuring the light intensity $2.5 \mathrm{~cm}$ from the light source, which is equal to the distance from the LED to the center of the cuvette holder. To measure the intensity of light emitted by the LEDs a Coherent FieldMax-Top Optical Power Meter equipped with a PM10 sensor was used.

\subsection{Synthesis}

o-TCO-TAMRA and a-TCO-TAMRA were synthesized as described previously. ${ }^{2}$<smiles></smiles>

a-TCO-TAMRA

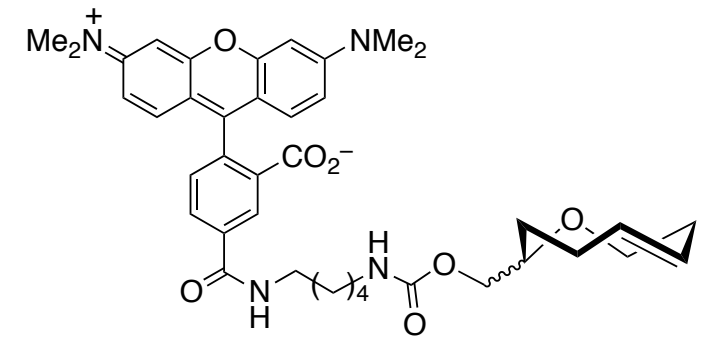

O-TCO-TAMRA

\section{Ethyl 2-oxo-2-(2-picolinoylhydrazineyl)acetate (4)}<smiles>NNC(=O)c1ccccn1</smiles><smiles>CCOC(=O)C(=O)Cl</smiles><smiles>CCOC(=O)C(=O)NNC(=O)c1ccccn1</smiles>

4

A round-bottom flask was charged with picolinic acid hydrazide (750 mg, $5.47 \mathrm{mmol}, 1$ equiv.), ethyl acetate $(25 \mathrm{~mL}, 0.2 \mathrm{M})$ and saturated sodium bicarbonate solution $(12 \mathrm{~mL})$. After stirring at r.t. for $5 \mathrm{~min}$, ethyl oxalyl chloride $(0.729 \mathrm{~mL}, 6.56 \mathrm{mmol}, 1.2$ equiv.) was added slowly in $5 \mathrm{~min}$ at $0{ }^{\circ} \mathrm{C}$. After stirring at r.t. for $1 \mathrm{~h}$, the mixture was transferred to a separatory funnel. The organic layer and aqueous layers were separated and the aqueous layer was extracted with ethyl acetate three times. The organics were combined, washed with brine, dried over sodium sulfate, 
filtered and concentrated by rotary evaporation. A white solid product (1.16 g, $5.03 \mathrm{mmol}, 92 \%)$ was obtained and used directly in next step without further purification. ${ }^{1} \mathrm{H} \mathrm{NMR}(400 \mathrm{MHz}$, $\left.\mathrm{CDCl}_{3}\right) \delta 8.61(\mathrm{ddd}, J=4.8,1.7,0.9 \mathrm{~Hz}, 1 \mathrm{H}), 8.17(\mathrm{dt}, J=7.8,1.1 \mathrm{~Hz}, 1 \mathrm{H}), 7.90(\mathrm{td}, J=7.7,1.7$ $\mathrm{Hz}, 1 \mathrm{H}), 7.51(\mathrm{ddd}, J=7.6,4.7,1.2 \mathrm{~Hz}, 1 \mathrm{H}), 4.43$ (q, $J=7.1 \mathrm{~Hz}, 2 \mathrm{H}), 1.42$ (t, $J=7.1 \mathrm{~Hz}, 3 \mathrm{H})$. ${ }^{13} \mathrm{C} \mathrm{NMR}\left(101 \mathrm{MHz}, \mathrm{CDCl}_{3}\right) \delta 160.55,158.86,152.31,148.80,147.62,137.69,127.39,122.80$, 63.87, 14.15. HRMS $[\mathrm{M}+\mathrm{H}]^{+} \mathrm{m} / \mathrm{z}$ calcd. for $\left[\mathrm{C}_{10} \mathrm{H}_{12} \mathrm{O}_{4} \mathrm{~N}_{3}\right]^{+} 238.0828$, found 238.0815

Ethyl (Z)-2-chloro-2-(((Z)-chloro(pyridin-2-yl)methylene)hydrazineylidene) acetate (5)<smiles>CCOC(=O)C(=O)NNC(=O)c1ccccn1</smiles>

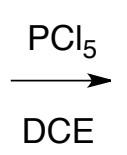<smiles>CCOC(=O)/C(Cl)=N/N=C(\Cl)c1ccccn1</smiles>

5

A dry round bottom flask was charged with 4 (900 mg, 3.79 mmol, 1 equiv.), phosphorous pentachloride (3.95 g, $18.9 \mathrm{mmol}, 5$ equiv.) and a magnetic stirbar. The flask was outfitted with a septum-fitted gas inlet adapter that was filled with $\mathrm{KOH}$ (using glass wool to plug the adapter) to serve as a trap for $\mathrm{HCl}$. The flask was evacuated and refilled with nitrogen. The gas inlet adapter was briefly removed and anhydrous dichloroethane $(25 \mathrm{~mL}, 0.15 \mathrm{M})$ was added by syringe. The mixture was refluxed under nitrogen at $85{ }^{\circ} \mathrm{C}$ for $2 \mathrm{~h}$ under nitrogen. The resulting solution was cooled down. Sodium bicarbonate solid (958 mg, $11.4 \mathrm{mmol}, 3$ equiv.) was added portionwise into mixture and stirred at r.t. for $30 \mathrm{~min}\left(\mathrm{CO}_{2}\right.$ gas is generated). The resulting solid was filtered on a Buchner funnel and washed with $\mathrm{CH}_{2} \mathrm{Cl}_{2}$. The filtrate was washed with saturated sodium bicarbonate solution until aqueous layer $\mathrm{pH}$ 7-8 and then washed with brine. The organics were dried over sodium sulfate and concentrated by rotary evaporation. The title compound was obtained as a yellow oil (561 mg, $2.05 \mathrm{mmol}, 54 \%)$ after column chromatography (hexane:ethyl acetate $100: 0$ to $93: 7) .{ }^{1} \mathrm{H}$ NMR $\left(600 \mathrm{MHz} \mathrm{CDCl}_{3}\right) \delta 8.76(\mathrm{ddd}, J=4.8,1.8,0.9 \mathrm{~Hz}, 1 \mathrm{H}), 8.16$ $(\mathrm{dt}, J=8.0,1.1 \mathrm{~Hz}, 1 \mathrm{H}), 7.84(\mathrm{td}, J=7.8,1.7 \mathrm{~Hz}, 1 \mathrm{H}), 7.46(\mathrm{ddd}, J=7.6,4.8,1.1 \mathrm{~Hz}, 1 \mathrm{H}), 4.47$ $(\mathrm{q}, J=7.1 \mathrm{~Hz}, 2 \mathrm{H}), 1.44(\mathrm{t}, J=7.2 \mathrm{~Hz}, 3 \mathrm{H}) .{ }^{13} \mathrm{C} \mathrm{NMR}\left(151 \mathrm{MHz}, \mathrm{CDCl}_{3}\right) \delta 158.57,149.89$, 
149.85, 142.35, 137.07, 133.74, 126.21, 123.48, 64.28, 14.20. HRMS $[\mathrm{M}+\mathrm{H}]^{+} \mathrm{m} / \mathrm{z}$ calcd. for $\left[\mathrm{C}_{10} \mathrm{H}_{10} \mathrm{O}_{2} \mathrm{~N}_{3} \mathrm{Cl}_{2}\right]^{+} 274.0105$, found 274.0137.

\section{Ethyl 6-(pyridin-2-yl)-1,4-dihydro-1,2,4,5-tetrazine-3-carboxylate (6)}<smiles>CCOC(=O)/C(Cl)=N/N=C(\Cl)c1ccccn1</smiles><smiles>CCOC(=O)C1=NNC(c2ccccn2)=NN1</smiles>

A dry round bottom flask was charged with $5(500 \mathrm{mg}, 3.18 \mathrm{mmol}, 1$ equiv.) and a magnetic stirbar. The flask was outfitted with a septum-fitted gas inlet adapter, evacuated and refilled with nitrogen. Anhydrous ethanol (15 mL, 0.2 M in 5) and anhydrous hydrazine (105 $\mu \mathrm{L}, 3.33 \mathrm{mmol}$, 1.05 equiv.) was added by syringe. The resulting mixture was heated to reflux (oil bath temperature $80^{\circ} \mathrm{C}$ ) under nitrogen for $2 \mathrm{~h}$. After cooling to room temperature, the resulting mixture was diluted with $\mathrm{CH}_{2} \mathrm{Cl}_{2}$, washed with water and brine, dried over sodium sulfate and concentrated by rotary evaporation. The title compound was obtained as a yellow solid (445 mg, $1.90 \mathrm{mmol}, 60 \%$ ) after column chromatography (hexane: ethyl acetate 100:0 to 85:15). ${ }^{1} \mathrm{H}$ NMR $\left(600 \mathrm{MHz}, \mathrm{CDCl}_{3}\right) \delta 8.68(\mathrm{~s}, 1 \mathrm{H}), 8.57-8.52(\mathrm{~m}, 1 \mathrm{H}), 8.03-7.93(\mathrm{~m}, 1 \mathrm{H}), 7.76(\mathrm{td}, J=7.8,1.7$ Hz, 1H), 7.41 (s, 1H), 7.37 (ddd, $J=7.5,4.9,1.2 \mathrm{~Hz}, 1 \mathrm{H}), 4.39$ (q, $J=7.2 \mathrm{~Hz}, 2 \mathrm{H}), 1.39$ (t, $J=$ $7.2 \mathrm{~Hz}, 3 \mathrm{H}) .{ }^{13} \mathrm{C} \mathrm{NMR}\left(151 \mathrm{MHz}, \mathrm{CDCl}_{3}\right) \delta 159.57,148.62,146.63,145.30,139.88,137.00$, 125.41, 121.68, 63.16, 14.22. HRMS $[\mathrm{M}+\mathrm{H}]^{+} \mathrm{m} / \mathrm{z}$ calcd. for $\left[\mathrm{C}_{10} \mathrm{H}_{10} \mathrm{O}_{2} \mathrm{~N}_{5}\right]^{+}$234.0991, found 234.0980 . 
N-Butyl-6-(pyridin-2-yl)-1,4-dihydro-1,2,4,5-tetrazine-3-carboxamide (1a)

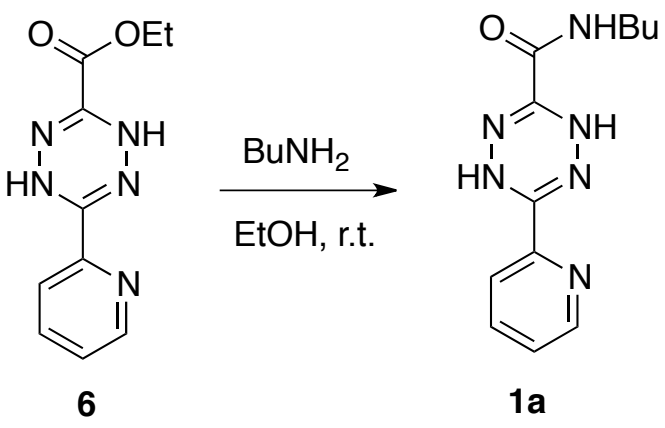

A dry round-bottom flask was charged with 6 (196 mg, $0.839 \mathrm{mmol}, 1$ equiv.) and a magnetic stirbar. The flask was outfitted with a septum-fitted gas inlet adapter, evacuated and refilled with nitrogen. Anhydrous ethanol (5 mL, 0.15 M in 6) and butylamine $(207 \mu \mathrm{L}, 2.10 \mathrm{mmol}, 2.5$ equiv.) were added via syringe. After stirring overnight under nitrogen at r.t., the resulting mixture was diluted with $\mathrm{CH}_{2} \mathrm{Cl}_{2}$, washed with water and brine, dried over sodium sulfate and concentrated by rotary evaporation. The title compound was obtained as a yellow solid (179 mg, $0.688 \mathrm{mmol}, 82 \%)$ after column chromatography $\left(\mathrm{CH}_{2} \mathrm{Cl}_{2}\right.$ : acetone 10:0 to 9:1). ${ }^{1} \mathrm{H}$ NMR (600 $\left.\mathrm{MHz}, \mathrm{CDCl}_{3}\right) \delta 8.52-8.45(\mathrm{~m}, 1 \mathrm{H}), 8.34(\mathrm{~s}, 1 \mathrm{H}), 7.98-7.85(\mathrm{~m}, 1 \mathrm{H}), 7.69(\mathrm{td}, J=7.7,1.7 \mathrm{~Hz}$ 1H), 7.63 (s, 1H), 7.29 (ddd, $J=7.5,4.9,1.2 \mathrm{~Hz}, 1 \mathrm{H}), 6.80(\mathrm{~s}, 1 \mathrm{H}), 3.27$ (td, $J=7.1,6.1 \mathrm{~Hz}$, 2H), $1.51-1.42(\mathrm{~m}, 2 \mathrm{H}), 1.38-1.24(\mathrm{~m}, 2 \mathrm{H}), 0.86(\mathrm{t}, J=7.4 \mathrm{~Hz}, 3 \mathrm{H}) .{ }^{13} \mathrm{C} \mathrm{NMR}(151 \mathrm{MHz}$, $\left.\mathrm{CDCl}_{3}\right) \delta 158.45,148.49,147.09,145.69,141.96,137.01,125.28,121.75,39.48,31.57,20.13$ 13.81. HRMS $[\mathrm{M}+\mathrm{H}]^{+} \mathrm{m} / \mathrm{z}$ calcd. for $\left[\mathrm{C}_{12} \mathrm{H}_{17} \mathrm{ON}_{6}\right]^{+} 261.1464$, found 261.1453

$N, N$-bis(2-Hydroxyethyl)-6-(pyridin-2-yl)-1,4-dihydro-1,2,4,5-tetrazine-3-carboxamide (1b)<smiles>CCOC(=O)C1=NNC(c2ccccn2)=NN1</smiles>

6

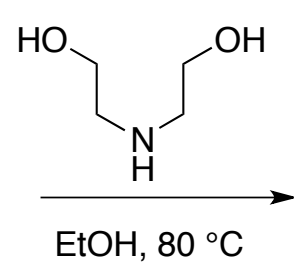<smiles>O=C(C1=NNC(c2ccccn2)=NN1)N(CCO)CCO</smiles> 
A dry round-bottom flask was charged with $6(30.8 \mathrm{mg}, 0.132 \mathrm{mmol}, 1$ equiv. $)$ and a magnetic stirbar. The flask was outfitted with a septum-fitted gas inlet adapter, evacuated and refilled with nitrogen. Anhydrous ethanol $(1.3 \mathrm{~mL}, 0.1 \mathrm{M}$ in 6) and diethanolamine $(38.0 \mu \mathrm{L}, 0.396 \mathrm{mmol}, 3$ equiv.) was added via syringe. After stirring overnight under nitrogen at r.t., the resulting mixture was diluted with $\mathrm{CH}_{2} \mathrm{Cl}_{2}$, washed with water and brine, dried over sodium sulfate and concentrated by rotary evaporation. The title compound was obtained as a yellow solid (26.8 mg, $0.0924 \mathrm{mmol}, 70 \%)$ after column chromatography $\left(\mathrm{CH}_{2} \mathrm{Cl}_{2}: \mathrm{MeOH} 100: 0\right.$ to 97:3). ${ }^{1} \mathrm{H}$ NMR (600 $\mathrm{MHz}, \mathrm{MeOD}) \delta 8.63-8.59(\mathrm{~m}, 1 \mathrm{H}), 8.05-7.91(\mathrm{~m}, 1 \mathrm{H}), 7.86(\mathrm{td}, J=7.8,1.7 \mathrm{~Hz}, 1 \mathrm{H}), 7.45$ (ddd, $J=7.6,4.9,1.2 \mathrm{~Hz}, 1 \mathrm{H}), 3.85(\mathrm{t}, J=5.7 \mathrm{~Hz}, 2 \mathrm{H}), 3.78-3.74(\mathrm{~m}, 4 \mathrm{H}), 3.63(\mathrm{t}, J=5.7 \mathrm{~Hz}$, 2H). ${ }^{13} \mathrm{C}$ NMR (151 MHz, MeOD) $\delta$ 163.50, 149.80, 148.54, 147.29, 145.13, 138.26, 126.44, 122.56, 61.19, 60.23, 53.11, 51.16. HRMS $[\mathrm{M}+\mathrm{H}]^{+} \mathrm{m} / \mathrm{z}$ calcd. for $\left[\mathrm{C}_{12} \mathrm{H}_{17} \mathrm{O}_{3} \mathrm{~N}_{6}\right]^{+} 293.1362$, found 293.1355

\section{N-Butyl-6-(pyridin-2-yl)-1,2,4,5-tetrazine-3-carboxamide (2a)}

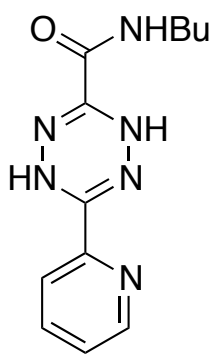

$1 \mathrm{a}$

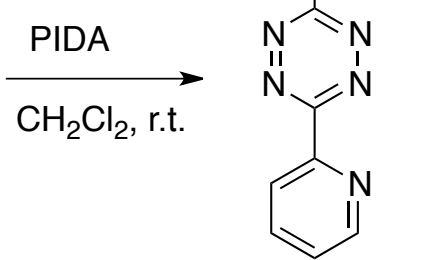

$2 a$

A dry round-bottom flask was charged with $1 \mathrm{a}(90.0 \mathrm{mg}, 0.346 \mathrm{mmol}, 1$ equiv.), PIDA (222 mg, $0.692 \mathrm{mmol}, 2$ equiv. $)$, anhydrous $\mathrm{CH}_{2} \mathrm{Cl}_{2}(3.5 \mathrm{ml}, 0.1 \mathrm{M}$ in 1a) and a magnetic stirbar. After stirring at r.t. for $4 \mathrm{~h}$, the resulting mixture was diluted with hexane and loaded directly onto a column of silica gel. The title compound was obtained as a pink solid (51.8 $\mathrm{mg}, 0.201 \mathrm{mmol}$, 58\%) after column chromatography (hexane: acetone 10:0 to 75:25). A minor impurity was noted in the ${ }^{13} \mathrm{C}$ NMR spectrum at $30 \mathrm{ppm} .{ }^{1} \mathrm{H}$ NMR $\left(400 \mathrm{MHz}, \mathrm{CDCl}_{3}\right) \delta 9.07-8.91(\mathrm{~m}, 1 \mathrm{H})$, $8.75(\mathrm{~d}, J=7.9 \mathrm{~Hz}, 1 \mathrm{H}), 8.08-7.91(\mathrm{~m}, 2 \mathrm{H}), 7.62(\mathrm{ddd}, J=7.7,4.7,1.1 \mathrm{~Hz}, 1 \mathrm{H}), 3.65(\mathrm{~m}, 2 \mathrm{H})$, 
$1.78-1.64(\mathrm{~m}, 2 \mathrm{H}), 1.54-1.39(\mathrm{~m}, 2 \mathrm{H}), 0.98(\mathrm{t}, J=7.4 \mathrm{~Hz}, 3 \mathrm{H}) .{ }^{13} \mathrm{C}$ NMR (101 MHz, $\left.\mathrm{CDCl}_{3}\right)$

$\delta 164.88(\mathrm{C}), 158.75(\mathrm{C}), 158.08(\mathrm{C}), 151.39(\mathrm{CH}), 149.43(\mathrm{C}), 137.80(\mathrm{CH}), 127.32(\mathrm{CH})$, 125.30 (CH), $40.14\left(\mathrm{CH}_{2}\right), 31.52\left(\mathrm{CH}_{2}\right), 20.23\left(\mathrm{CH}_{2}\right), 13.87\left(\mathrm{CH}_{3}\right)$. HRMS $[\mathrm{M}+\mathrm{H}]^{+} \mathrm{m} / \mathrm{z}$ calcd. for $\left[\mathrm{C}_{12} \mathrm{H}_{15} \mathrm{ON}_{6}\right]^{+} 259.1307$, found 259.1298

$N$-(2-(2-((6-Chlorohexyl)oxy)ethoxy)ethyl)-6-(pyridin-2-yl)-1,4-dihydro-1,2,4,5-tetrazine-3carboxamide (1c)

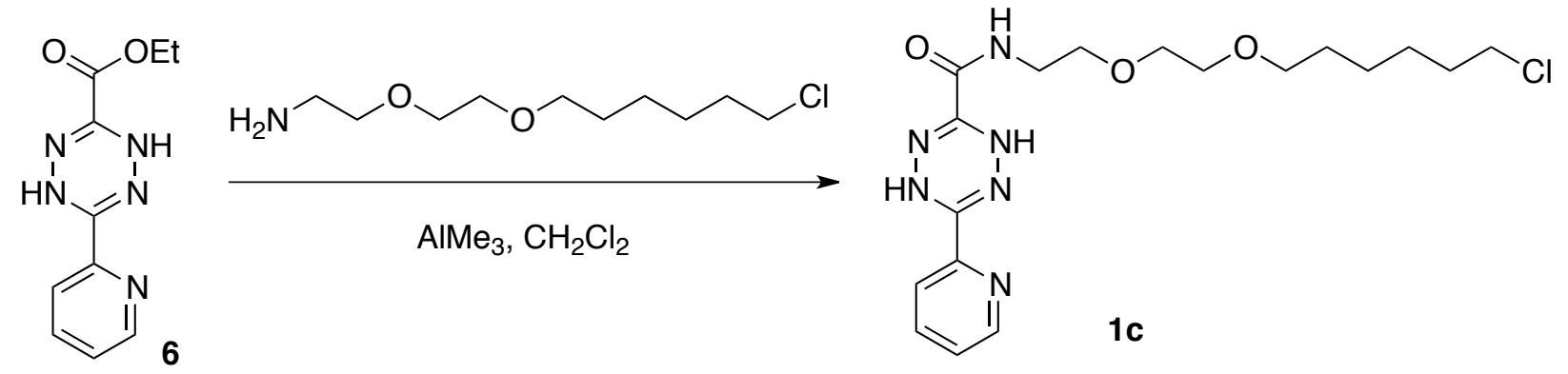

A dry round-bottom flask was charged with 2-(2-((6-chlorohexyl)oxy)ethoxy)ethan-1-

amine $\cdot \mathrm{HCl}$ (40 mg, $0.15 \mathrm{mmol}, 1$ equiv.) and a magnetic stirbar. The flask was outfitted with a septum-fitted gas inlet adapter, evacuated and refilled with nitrogen. Anhydrous $\mathrm{CH}_{2} \mathrm{Cl}_{2}(2 \mathrm{~mL})$ and trimethylaluminum ( $2 \mathrm{M}$ toluene solution, $0.15 \mathrm{~mL}, 0.31 \mathrm{mmol}, 2$ equiv.) was added by syringe. The mixture was stirred under nitrogen at r.t. for $1 \mathrm{~h} .6(54 \mathrm{mg}, 0.23 \mathrm{mmol}, 1.5$ equiv.) in anhydrous $\mathrm{CH}_{2} \mathrm{Cl}_{2}(4 \mathrm{~mL})$ was added at room temperature. After refluxing under nitrogen at $40{ }^{\circ} \mathrm{C}$ for $2 \mathrm{~h}$, the resulting mixture was diluted with $\mathrm{CH}_{2} \mathrm{Cl}_{2}$, washed sequentially with saturated sodium bicarbonate solution, water and brine, dried over sodium sulfate and concentrated by rotary evaporation. The title compound was obtained as a yellow solid $(36 \mathrm{mg}, 0.088 \mathrm{mmol}$, $57 \%$ ) after column chromatography (hexane:ethyl acetate 8:2 to $6: 4$ ). ${ }^{1} \mathrm{H}$ NMR (600 MHz, $\left.\mathrm{CDCl}_{3}\right) \delta 8.59-8.48(\mathrm{~m}, 1 \mathrm{H}), 8.40(\mathrm{~s}, 1 \mathrm{H}), 8.09-7.91(\mathrm{~m}, 1 \mathrm{H}), 7.76(\mathrm{td}, J=7.7,1.7 \mathrm{~Hz}, 1 \mathrm{H})$, 7.64 (s, 1H), 7.36 (ddd, $J=7.5,4.9,1.2 \mathrm{~Hz}, 1 \mathrm{H}), 3.70-3.50$ (m, 10H), 3.47 (t, $J=6.7 \mathrm{~Hz}, 2 \mathrm{H})$, $1.78(\mathrm{dt}, J=14.6,6.8 \mathrm{~Hz}, 2 \mathrm{H}), 1.61(\mathrm{dt}, J=14.2,6.8 \mathrm{~Hz}, 2 \mathrm{H}), 1.50-1.42(\mathrm{~m}, 2 \mathrm{H}), 1.42-1.35$ (m, 2H). ${ }^{13} \mathrm{C}$ NMR (101 MHz, $\left.\mathrm{CDCl}_{3}\right) \delta 158.43(\mathrm{C}), 148.37(\mathrm{CH}), 146.86(\mathrm{C}), 145.53(\mathrm{C})$, 
$141.59(\mathrm{C}), 136.91(\mathrm{CH}), 125.20(\mathrm{CH}), 121.59(\mathrm{CH}), 71.36\left(\mathrm{CH}_{2}\right), 70.45\left(\mathrm{CH}_{2}\right), 70.04\left(\mathrm{CH}_{2}\right)$,

69.44, $\left(\mathrm{CH}_{2}\right) 45.11\left(\mathrm{CH}_{2}\right), 39.36\left(\mathrm{CH}_{2}\right), 32.54\left(\mathrm{CH}_{2}\right), 29.47\left(\mathrm{CH}_{2}\right), 26.72\left(\mathrm{CH}_{2}\right), 25.43\left(\mathrm{CH}_{2}\right)$.

tert-butyl (R)-3-(((benzyloxy)carbonyl)amino)-1-oxa-8-azaspiro[4.5]decane-8-carboxylate (15)

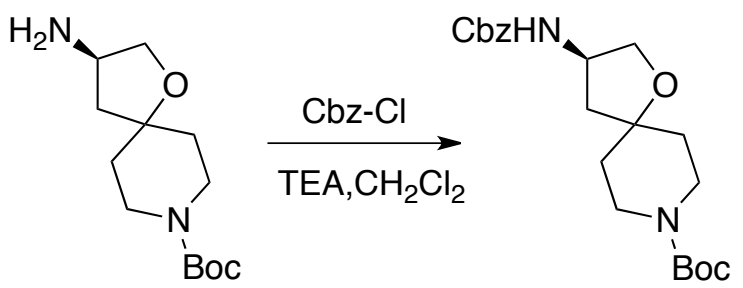

15

A dry round-bottom flask was charged with tert-butyl ( $R$ )-3-amino-1-oxa-8-azaspiro[4.5]decane8-carboxylate (290 mg, $1.131 \mathrm{mmol}, 1$ equiv.), $\mathrm{CH}_{2} \mathrm{Cl}_{2}(5 \mathrm{~mL})$, trimethylamine (238 $\mu \mathrm{L}, 1.70$ mmol, 1.5 equiv.) and a magnetic stirbar. At $0{ }^{\circ} \mathrm{C}$, benzyl chloroformate $(194 \mu \mathrm{L}, 1.36 \mathrm{mmol}, 1.2$ equiv.) in $\mathrm{CH}_{2} \mathrm{Cl}_{2}(1 \mathrm{~mL})$ was added by syringe slowly. After stirring under nitrogen at r.t. overnight, the mixture was diluted with $\mathrm{CH}_{2} \mathrm{Cl}_{2}$, washed sequentially with saturated sodium bicarbonate solution, water and brine, dried over sodium sulfate and concentrated by rotary evaporation. The title compound was obtained as a white solid (362 mg, $0.927 \mathrm{mmol}, 82 \%$ ) after column chromatography $\left(\mathrm{CH}_{2} \mathrm{Cl}_{2}: \mathrm{MeOH}\right.$ 100:0 to 95:5) that was carried through the next step without additional purification. ${ }^{1} \mathrm{H}$ NMR $\left(400 \mathrm{MHz}, \mathrm{CDCl}_{3}\right) \delta 7.44-7.30(\mathrm{~m}, 5 \mathrm{H}), 5.08(\mathrm{~s}, 2 \mathrm{H})$, $5.00(\mathrm{~m}, 1 \mathrm{H}), 4.41-4.27(\mathrm{~m}, 1 \mathrm{H}), 3.98(\mathrm{dd}, J=9.6,5.7 \mathrm{~Hz}, 1 \mathrm{H}), 3.78-3.46(\mathrm{~m}, 3 \mathrm{H}), 3.46-$ $3.07(\mathrm{~m}, 2 \mathrm{H}), 2.11(\mathrm{dd}, J=13.3,7.6 \mathrm{~Hz}, 1 \mathrm{H}), 1.70-1.53(\mathrm{~m}, 4 \mathrm{H}), 1.53-1.48(\mathrm{~m}, 1 \mathrm{H}), 1.44(\mathrm{~s}$, 9H). HRMS $[\mathrm{M}+\mathrm{H}]^{+} \mathrm{m} / \mathrm{z}$ calcd. for $\left[\mathrm{C}_{21} \mathrm{H}_{31} \mathrm{O}_{5} \mathrm{~N}_{2}\right]^{+}$391.2233, found 391.2209. 


\section{1,1,1,3,3,3-hexafluoropropan-2-yl (R)-3-(((benzyloxy)carbonyl)amino)-1-oxa-8-}

azaspiro[4.5]decane-8-carboxylate (16)

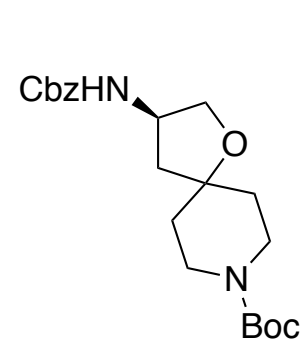

15
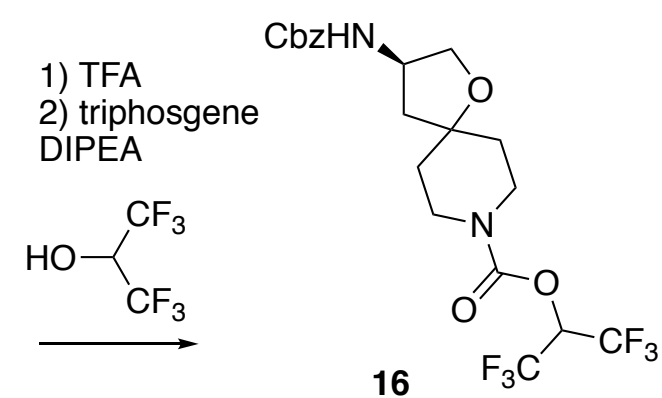

The first dry round-bottom flask was charged with 15 (190 mg, 0.487 mmol, 1 equiv.), $\mathrm{CH}_{2} \mathrm{Cl}_{2}$ (4 mL), trifluoroacetic acid (745 $\mu \mathrm{L}, 9.73 \mathrm{mmol}, 20$ equiv.) and a magnetic stirbar. After stirring at r.t. for $4 \mathrm{~h}$, the resulting mixture was concentrated by rotary evaporation. The secondary dry round-bottom flask was charged with triphosgene (289 mg, $0.973 \mathrm{mmol}, 2$ equiv.), $\mathrm{CH}_{2} \mathrm{Cl}_{2}$ (2 $\mathrm{mL}$ ) and a magnetic stirbar, and cooled in ice bath to $0{ }^{\circ} \mathrm{C}$. A mixture of $1,1,1,3,3,3$-Hexafluoro2-propanol (307 $\mu \mathrm{L}, 2.920 \mathrm{mmol}, 6$ equiv.) and triethylamine (1.03 mL, $7.30 \mathrm{mmol}, 15$ equiv.) in $\mathrm{CH}_{2} \mathrm{Cl}_{2}(6 \mathrm{~mL})$ was added into the flask in $30 \mathrm{~min}$ with syringe pump at $0{ }^{\circ} \mathrm{C}$. The resulting mixture was stirred under nitrogen at r.t. for $2 \mathrm{~h}$. The mixture in first flask was redissolved in $\mathrm{CH}_{2} \mathrm{Cl}_{2}(4 \mathrm{~mL})$ and added into the second flask by syringe followed by triethylamine $(1.03 \mathrm{~mL}$, $7.30 \mathrm{mmol}, 15$ equiv.). After stirring under nitrogen at r.t. overnight, the mixture was diluted with $\mathrm{CH}_{2} \mathrm{Cl}_{2}$, washed with water and brine, dried over sodium sulfate and concentrated by rotary evaporation. The title compound was obtained as a white solid (212 mg, $0.438 \mathrm{mmol}, 90 \%$ after column chromatography $\left(\mathrm{CH}_{2} \mathrm{Cl}_{2}: \mathrm{MeOH} 100: 0\right.$ to 99:1). ${ }^{1} \mathrm{H}$ NMR $\left(400 \mathrm{MHz}, \mathrm{CDCl}_{3}\right) \delta 7.53-$ $7.30(\mathrm{~m}, 5 \mathrm{H}), 5.75$ (hept, $J=6.3 \mathrm{~Hz}, 1 \mathrm{H}), 5.09(\mathrm{~s}, 2 \mathrm{H}), 5.02-4.87(\mathrm{~m}, 1 \mathrm{H}), 4.54-4.26(\mathrm{~m}, 1 \mathrm{H})$, $4.00(\mathrm{dd}, J=9.8,5.7 \mathrm{~Hz}, 1 \mathrm{H}), 3.95-3.75(\mathrm{~m}, 2 \mathrm{H}), 3.68(\mathrm{dd}, J=9.6,4.2 \mathrm{~Hz}, 1 \mathrm{H}), 3.45-3.13$ $(\mathrm{m}, 2 \mathrm{H}), 2.14(\mathrm{dd}, J=13.5,7.6 \mathrm{~Hz}, 1 \mathrm{H}), 1.93-1.45(\mathrm{~m}, 5 \mathrm{H})$. Two rotamers: ${ }^{13} \mathrm{C}$ NMR $(101$ $\left.\mathrm{MHz}, \mathrm{CDCl}_{3}\right) \delta 155.86(\mathrm{C}), 151.50(\mathrm{C}), 136.29(\mathrm{C}), 128.73(\mathrm{C}), 128.44(\mathrm{C}), 128.35(\mathrm{C}), 120.84$ (q, J = 280.5 Hz, C), $79.26\left(\mathrm{CH}_{2}\right), 71.71(\mathrm{C}), 68.16$ (hept, $\left.\mathrm{J}=34.2 \mathrm{~Hz}, \mathrm{CH}\right), 67.09\left(\mathrm{CH}_{2}\right), 52.17$ $(\mathrm{CH}), 44.68\left(\mathrm{CH}_{2}\right), 42.25\left(\mathrm{CH}_{2}\right), 42.19\left(\mathrm{CH}_{2}\right), 41.61\left(\mathrm{CH}_{2}\right), 41.52\left(\mathrm{CH}_{2}\right), 37.33\left(\mathrm{CH}_{2}\right), 36.96$ 
$\left(\mathrm{CH}_{2}\right), 35.81\left(\mathrm{CH}_{2}\right), 35.44\left(\mathrm{CH}_{2}\right)$. HRMS $[\mathrm{M}+\mathrm{H}]^{+} \mathrm{m} / \mathrm{z}$ calcd. for $\left[\mathrm{C}_{20} \mathrm{H}_{23} \mathrm{O}_{5} \mathrm{~N}_{2} \mathrm{~F}_{6}\right]^{+} 485.1511$, found 485.1491 .

\section{1,1,1,3,3,3-hexafluoropropan-2-yl $(R)$-3-amino-1-oxa-8-azaspiro[4.5]decane-8-carboxylate}

(17)

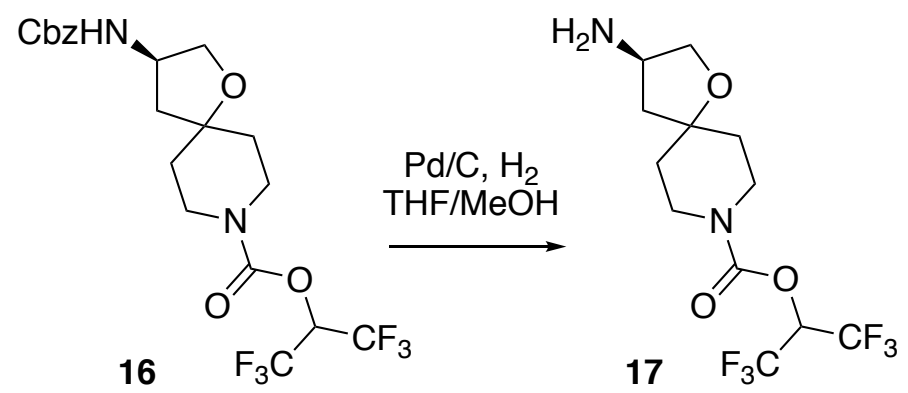

A dry round-bottom flask was charged with 16 (237 mg, 0.489 mmol, 1 equiv.), 5\% Pd/C (104 mg, 0.0489, 0.1 equiv.) and a magnetic stirbar. The flask was outfitted with a septum-fitted gas inlet adapter, evacuated and refilled with nitrogen. Anhydrous THF (1.5 mL) and MeOH (6 mL) was added by syringe. After stirring under hydrogen at r.t. overnight, the resulting mixture was filtered over celite, celite was washed with THF and MeOH. All organic fractions were combined and concentrated by rotary evaporation. The title compound was obtained as a colorless oil (147 mg, $0.420 \mathrm{mmol}, 85 \%)$ after column chromatography $\left(\mathrm{CH}_{2} \mathrm{Cl}_{2}: \mathrm{MeOH} 10: 0\right.$ to 9:1). ${ }^{1} \mathrm{H}$ NMR (400 MHz, MeOD) $\delta 6.29-6.02(\mathrm{~m}, 1 \mathrm{H}), 4.00(\mathrm{dd}, J=9.4,5.5 \mathrm{~Hz}, 1 \mathrm{H}), 3.90-$ $3.61(\mathrm{~m}, 3 \mathrm{H}), 3.57(\mathrm{t}, J=5.9 \mathrm{~Hz}, 1 \mathrm{H}), 3.51-3.36(\mathrm{~m}, 2 \mathrm{H}), 2.31-2.12(\mathrm{~m}, 1 \mathrm{H}), 1.91-1.46(\mathrm{~m}$, 6H).Two rotamers: ${ }^{13} \mathrm{C}$ NMR (101 MHz, MeOD) $\delta 152.61$ (C), 122.41 (q, J = 280.5 Hz, C), $81.08(\mathrm{C}), 80.97(\mathrm{C}), 72.59\left(\mathrm{CH}_{2}\right), 71.23\left(\mathrm{CH}_{2}\right), 69.11$ (hept, $\left.\mathrm{J}=34.2 \mathrm{~Hz}, \mathrm{C}\right), 59.56(\mathrm{CH}), 52.79$ $(\mathrm{CH}), 45.25\left(\mathrm{CH}_{2}\right), 43.40\left(\mathrm{CH}_{2}\right), 43.65\left(\mathrm{CH}_{2}\right), 43.13\left(\mathrm{CH}_{2}\right), 42.80\left(\mathrm{CH}_{2}\right), 42.53\left(\mathrm{CH}_{2}\right), 37.92$ $\left(\mathrm{CH}_{2}\right), 37.56\left(\mathrm{CH}_{2}\right), 36.48\left(\mathrm{CH}_{2}\right), 36.15\left(\mathrm{CH}_{2}\right)$. HRMS $[\mathrm{M}+\mathrm{H}]^{+} \mathrm{m} / \mathrm{z}$ calcd. for $\left[\mathrm{C}_{12} \mathrm{H}_{17} \mathrm{O}_{3} \mathrm{~N}_{2} \mathrm{~F}_{6}\right]^{+}$ 351.1143, found 351.1124. 


\section{1,1,1,3,3,3-hexafluoropropan-2-yl (R)-3-(6-(pyridin-2-yl)-1,4-dihydro-1,2,4,5-tetrazine-3-}

carboxamido)-1-oxa-8-azaspiro[4.5]decane-8-carboxylate (14)

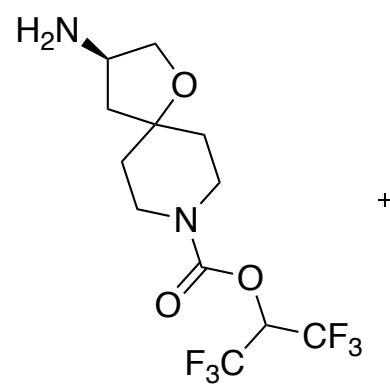

17

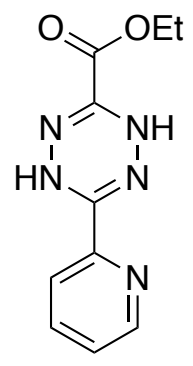

6

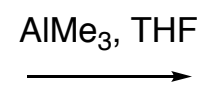

A dry round-bottom flask was charged with 17 (89 $\mathrm{mg}, 0.25 \mathrm{mmol}, 1$ equiv.) and a magnetic stirbar. The flask was outfitted with a septum-fitted gas inlet adapter, evacuated and refilled with nitrogen. Anhydrous THF (3 mL) and trimethylaluminium (2M toluene solution, $0.19 \mathrm{~mL}, 0.38$ mmol, 1.5 equiv.) was added by syringe. The mixture was stirred under nitrogen at r.t. for 1 h. 6 (71 mg, $0.30 \mathrm{mmol}, 1.2$ equiv.) in anhydrous THF ( $5 \mathrm{~mL})$ was added. After heating under nitrogen at $60{ }^{\circ} \mathrm{C}$ for $2 \mathrm{~h}$, the resulting mixture was diluted with $\mathrm{CH}_{2} \mathrm{Cl}_{2}$, washed sequentially with saturate sodium bicarbonate solution, water and brine, dried over sodium sulfate and concentrated by rotary evaporation. The title compound was obtained as a yellow solid (68 $\mathrm{mg}$, $0.13 \mathrm{mmol}, 50 \%$ ) after column chromatography (hexane:ethyl acetate 10:0 to 6:4). ${ }^{1} \mathrm{H}$ NMR (400 $\left.\mathrm{MHz}, \mathrm{CDCl}_{3}\right) \delta 8.59-8.51(\mathrm{~m}, 1 \mathrm{H}), 8.46(\mathrm{~s}, 1 \mathrm{H}), 8.15-7.94(\mathrm{~m}, 1 \mathrm{H}), 7.76(\mathrm{td}, J=7.7,1.7 \mathrm{~Hz}$, 1H), 7.67 (s, 1H), 7.37 (ddd, $J=7.5,4.9,1.2 \mathrm{~Hz}, 1 \mathrm{H}), 7.05$ (d, $J=7.8 \mathrm{~Hz}, 1 \mathrm{H}), 5.75$ (hept, $J=$ $6.2 \mathrm{~Hz}, 1 \mathrm{H}), 4.67-4.44(\mathrm{~m}, 1 \mathrm{H}), 4.02(\mathrm{ddd}, J=9.7,5.6,1.2 \mathrm{~Hz}, 1 \mathrm{H}), 3.93-3.78(\mathrm{~m}, 2 \mathrm{H}), 3.75$ $(\mathrm{dd}, J=9.8,3.9 \mathrm{~Hz}, 1 \mathrm{H}), 3.49-3.28(\mathrm{~m}, 2 \mathrm{H}), 2.17(\mathrm{dd}, J=13.5,7.6 \mathrm{~Hz}, 1 \mathrm{H}), 1.88-1.50(\mathrm{~m}$, 5H). Two rotamers: ${ }^{13} \mathrm{C}$ NMR $\left(101 \mathrm{MHz}, \mathrm{CDCl}_{3}\right) \delta 158.22(\mathrm{C}), 158.21(\mathrm{C}), 151.49(\mathrm{C}), 148.52$ $(\mathrm{CH}), 146.84(\mathrm{C}), 145.65(\mathrm{C}), 141.52(\mathrm{C}), 137.08(\mathrm{CH}), 125.42(\mathrm{CH}), 121.77(\mathrm{CH}), 120.84(\mathrm{q}, \mathrm{J}$ $=280.5 \mathrm{~Hz}, \mathrm{C}), 79.42\left(\mathrm{CH}_{2}\right), 71.19(\mathrm{C}), 68.16$ (hept, J = 34.2 Hz, C), $50.83(\mathrm{CH}), 50.80(\mathrm{CH})$, $44.48\left(\mathrm{CH}_{2}\right), 42.25\left(\mathrm{CH}_{2}\right), 42.19\left(\mathrm{CH}_{2}\right), 41.61\left(\mathrm{CH}_{2}\right), 41.51\left(\mathrm{CH}_{2}\right), 37.39\left(\mathrm{CH}_{2}\right), 36.99\left(\mathrm{CH}_{2}\right)$, $35.73\left(\mathrm{CH}_{2}\right), 35.38\left(\mathrm{CH}_{2}\right)$. HRMS $[\mathrm{M}+\mathrm{H}]^{+} \mathrm{m} / \mathrm{z}$ calcd. for $\left[\mathrm{C}_{20} \mathrm{H}_{22} \mathrm{O}_{4} \mathrm{~N}_{7} \mathrm{~F}_{6}\right]^{+}$538.1637, found 538.1613. 
5-((2-Aminoethyl)carbamoyl)-2-(7-(dimethylamino)-3-(dimethyliminio)-5,5-dimethyl-3,5dihydrodibenzo[b,e] silin-10-yl)benzoate (S1)
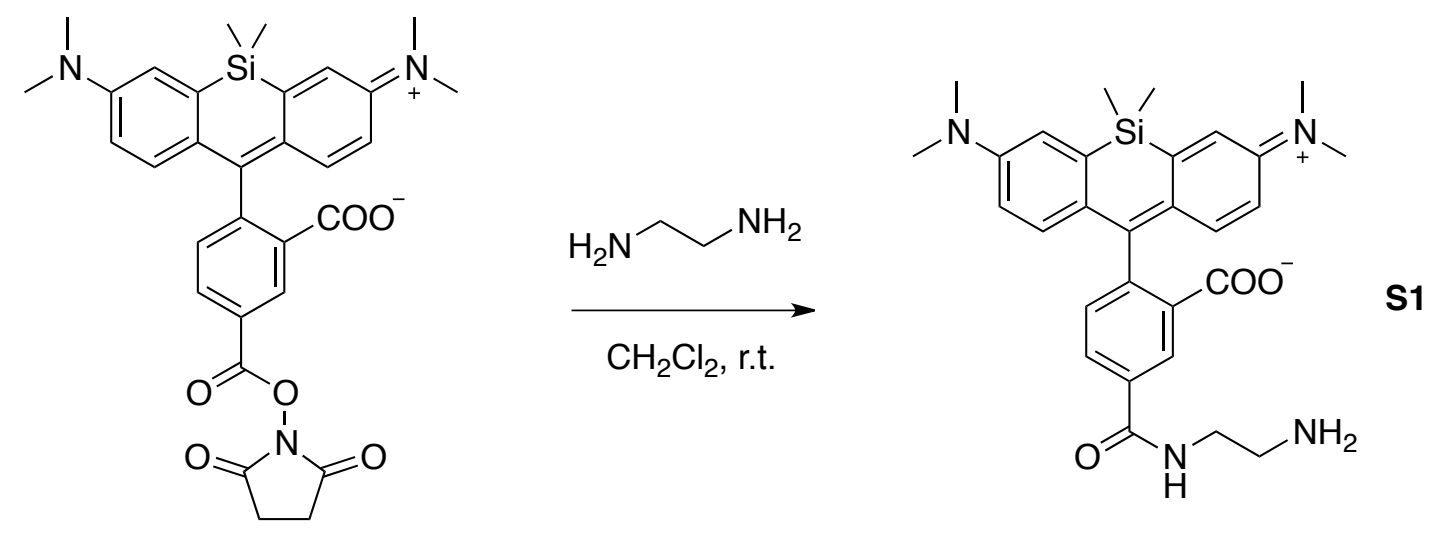

A dry round-bottom flask was charged with SiR-NHS ester (1.2 mg, $2.1 \mu \mathrm{mol}, 1$ equiv., Spirochrome cat\#: SC003) and a magnetic stirbar. The flask was outfitted with a septum-fitted gas inlet adapter, evacuated and refilled with nitrogen. Anhydrous $\mathrm{CH}_{2} \mathrm{Cl}_{2}(1 \mathrm{~mL})$ and ethylenediamine $(1.4 \mu \mathrm{L}, 21 \mu \mathrm{mol}, 10$ equiv.) were added by syringe. After stirring under nitrogen at r.t. overnight, the resulting mixture was concentrated by rotary evaporation. The title compound was obtained as a blue solid (1.0 mg, $1.9 \mu \mathrm{mol}, 92 \%)$ after reverse phase column chromatography with a Yamazen "14 g" C18-flash column $\left(\mathrm{H}_{2} \mathrm{O}\left(0.05 \% \mathrm{NH}_{4} \mathrm{OH}\right): \mathrm{MeOH}\right.$ 8:2 to 1:9). HRMS $[\mathrm{M}+\mathrm{H}]^{+} \mathrm{m} / \mathrm{z}$ calcd. for $\left[\mathrm{C}_{29} \mathrm{H}_{35} \mathrm{O}_{3} \mathrm{~N}_{4} \mathrm{Si}\right]^{+}$515.2478, found 515.2462 


\section{(E)-2-(7-(Dimethylamino)-3-(dimethylimino)-5,5-dimethyl-3,5-dihydrodibenzo[b,e]silin-10-}

\section{yl)-5-((2-(2-(1-hydroxycyclooct-4-en-1-yl)acetamido)ethyl)carbamoyl)benzoate (a-TCO-}

\section{SiR)}<smiles>CN(C)c1ccc2c(c1)[Si](C)(C)C1=CC(=[N+](C)C)C=CC1=C2c1ccc(C(=O)NCCN)cc1C(=O)[O-]</smiles>

S1

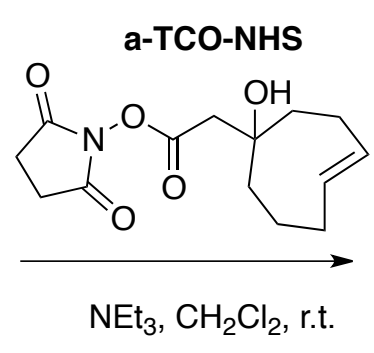

$\mathrm{NEt}_{3}, \mathrm{CH}_{2} \mathrm{Cl}_{2}$, r.t.<smiles>CN(C)c1ccc2c(c1)[Si](C)(C)C1=CC(=[N+](C)C)C=CC1=C2c1ccc(C(=O)NCCNC(=O)CC2(O)CC/C=C\CCC2)cc1C(=O)[O-]</smiles>

A dry round-bottom flask was charged with $\mathbf{S 1}(1.5 \mathrm{mg}, 2.9 \mu \mathrm{mol}, 1$ equiv.) and a magnetic stirbar. The flask was outfitted with a septum-fitted gas inlet adapter, evacuated and refilled with nitrogen. Anhydrous $\mathrm{CH}_{2} \mathrm{Cl}_{2}(1 \mathrm{~mL})$, triethylamine $(4.1 \mu \mathrm{L}, 29 \mu \mathrm{mol}, 10$ equiv.) and a-TCONHS $^{2}$ (3.1 mg, $12 \mu \mathrm{mol}, 4$ equiv) was added by syringe. After stirring under nitrogen at r.t. overnight, the resulting mixture was concentrated by rotary evaporation. The title compound was obtained as a blue solid (1.5 mg, $2.2 \mu \mathrm{mol}, 76 \%)$ after reverse phase column chromatography with a Yamazen "14 g" C18-flash column $\left(\mathrm{H}_{2} \mathrm{O}\left(0.05 \% \mathrm{NH}_{4} \mathrm{OH}\right): \mathrm{MeOH}\right.$ 10:0 to 10:1). ${ }^{1} \mathrm{H}$ NMR HRMS $[\mathrm{M}+\mathrm{H}]^{+} \mathrm{m} / \mathrm{z}$ calcd. for $\left[\mathrm{C}_{39} \mathrm{H}_{49} \mathrm{O}_{5} \mathrm{~N}_{4} \mathrm{Si}\right]^{+} 681.3472$, found 681.3442 . 


\subsection{Stability of DHTzs in PBS Buffer}

PBS buffer was filtered through chelex resin prior to use (see Section 4.2). The stability of DHTz 1a in PBS buffer was monitored by UV-vis: solutions of $40 \mu \mathrm{M}$ DHTz were prepared in PBS buffer at pH 7.4 and stored in ambient light at room temperature. The UV-vis spectra of solutions were obtained after 0,24 and 49 h (Figure S1)
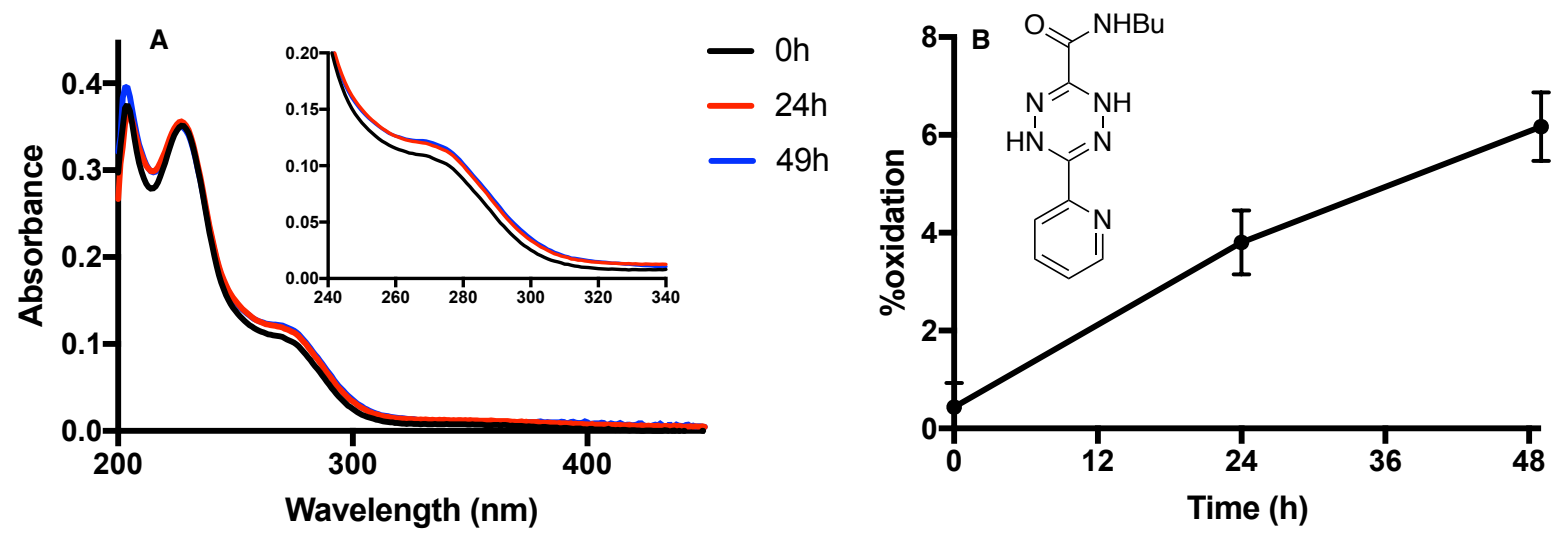

Figure S1 (A) UV-vis absorbance of DHTz 1a in PBS buffer after 0 h, $24 \mathrm{~h}$ and $49 \mathrm{~h}$. (B) DHTz 1a retained 96\% and 94\% DHTz oxidation state in PBS buffer after $24 \mathrm{~h}$ and $49 \mathrm{~h}$.

Stability of DHTz 1b in PBS buffer was monitored by NMR: Solutions of $25 \mathrm{mM} \mathrm{DHTz}$ and $50 \mathrm{mM}$ DMSO (as internal standard) were prepared in deuterated PBS buffer at $\mathrm{pH} 7.4$ and stored in ambient light at room temperature. ${ }^{1} \mathrm{H}$ NMR of solutions was obtained after $0,1,3$ and 5 days. (Figure S2) 

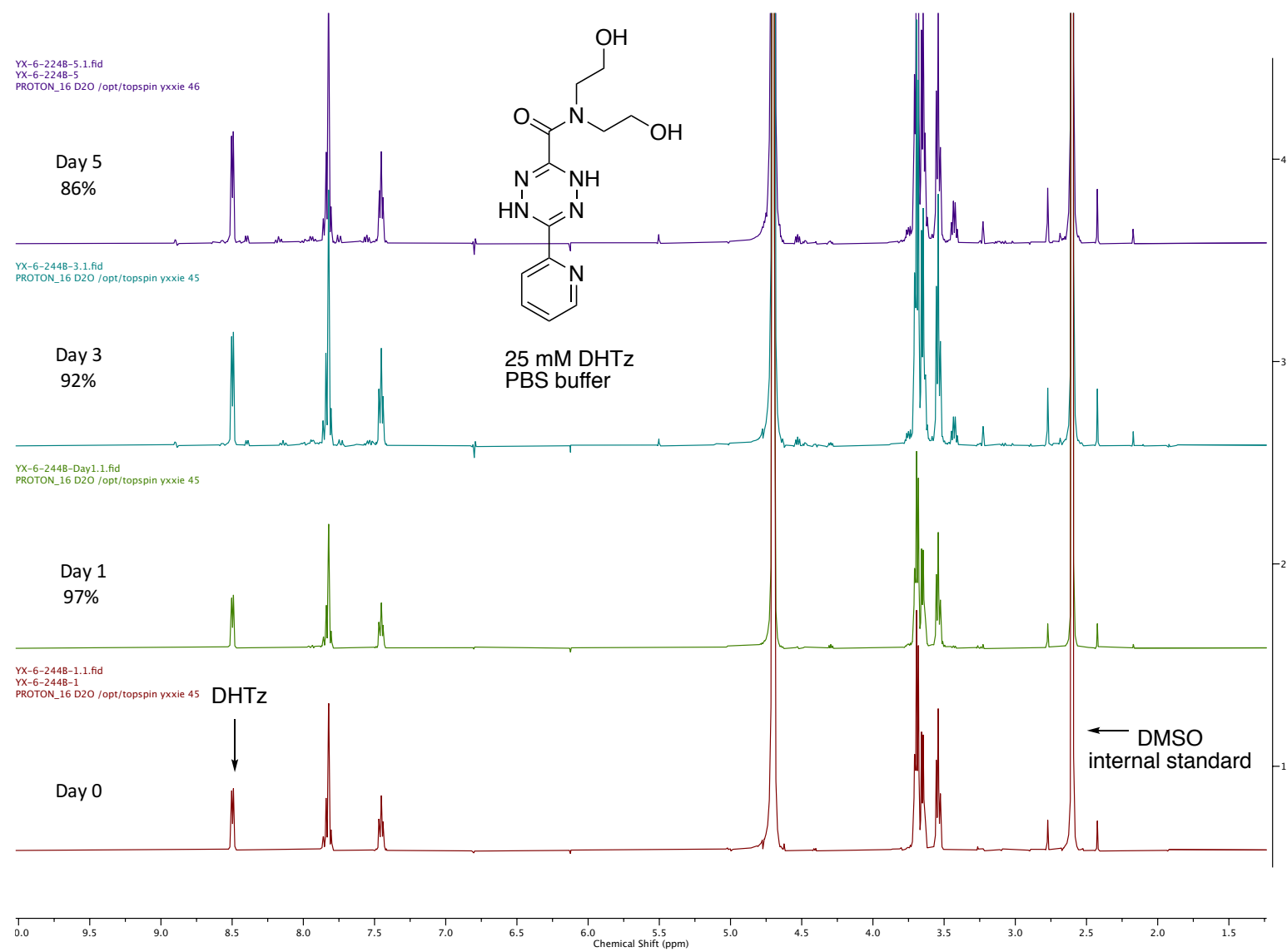

Figure S2 ${ }^{1} \mathrm{H}$ NMR of water soluble DHTz $\mathbf{1 b}$ in deuterated PBS after $0,1,3$, and 5 days. Based on the integration of proton of $\mathbf{1 b}$ at $8.5 \mathrm{ppm}$ and DMSO at $2.50 \mathrm{ppm}, \mathrm{DHTz} \mathbf{1 b}$ retained $97 \%, 92 \%$ and $86 \%$ DHTz oxidation state after 1,3 and 5 days.

\subsection{Stability of DHTzs in Serum Solution}

Stability of DHTz in serum: Solutions of $150 \mu \mathrm{M}$ of DHTz 1a were prepared in 10\% human serum in PBS in Eppendorf tubes. At the desired time point, $\mathrm{MeOH}(0.8 \mathrm{~mL})$ was added to the solution $(0.2 \mathrm{~mL})$ in order to precipitate serum proteins. After centrifugation, a clear solution was obtained and the initial absorbance (Abs 1) was measured by UV-vis. Methylene blue $(1 \mu \mathrm{M})$ was added and the solution was irradiated $(660 \mathrm{~nm})$ for 6 min to oxidize the DHTz and a final absorbance (Abs 2) was measured. The difference between initial and final absorbance $(\triangle \mathrm{A})$ at $280 \mathrm{~nm}$ was attributed to the conversion of remaining DHTz in the serum 
solution to tetrazine (Figure S3A). With a DHTz standard of known concentration, $\Delta \varepsilon$ for the oxidation of DHTz to Tz was calculated to be $4838 \pm 89.57 \mathrm{M}^{-1} \mathrm{~cm}^{-1}$ (Figure S3B).
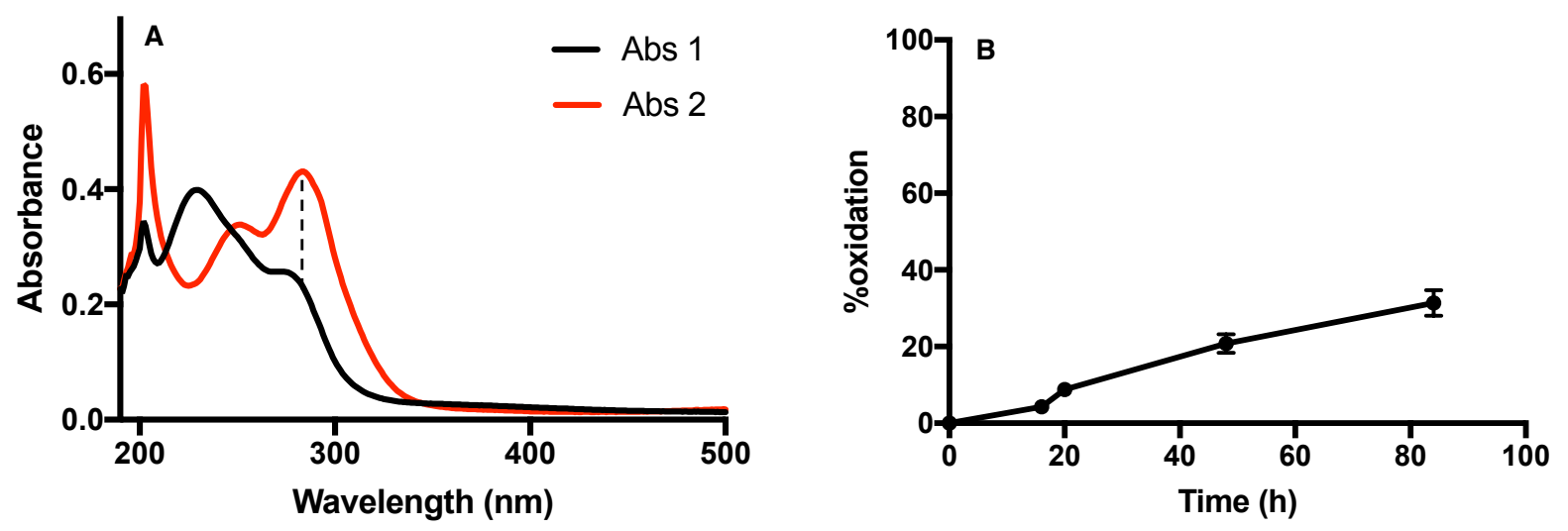

Figure S3 Stability of DHTz 1a in 10\% human serum in PBS. (A) Remaining DHTz was assayed by MB-catalyzed oxidation to tetrazine, which has increased absorption at $280 \mathrm{~nm}$. The amount of remaining tetrazine was determined by measuring the difference in absorption. (B) DHTz stability versus time. DHTz retained $92 \%, 81 \%$ and $71 \%$ DHTz oxidation state after $20 \mathrm{~h}$, $2 \mathrm{~d}$ and $3.5 \mathrm{~d}$ respectively.

\subsection{Stability of Tetrazines in PBS Buffer}<smiles>CCCCCNC(=O)c1nnc(-c2ccccn2)nn1</smiles>
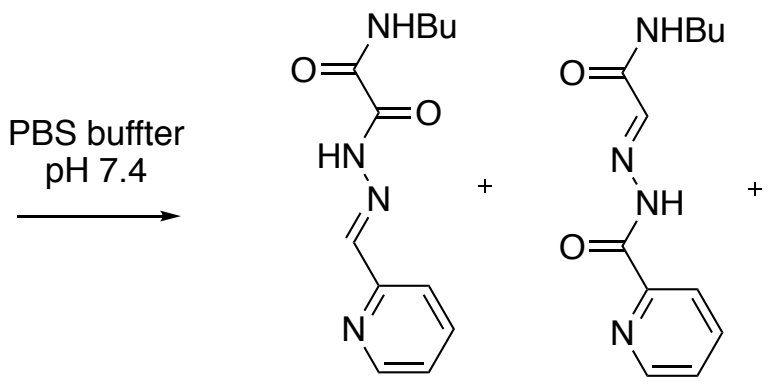<smiles>CCCCCNC(=O)c1nnc(-c2ccccn2)o1</smiles>

The hydrolysis of Tetrazine results in three types of products which were observed in LCMS: two isomeric acylhydrazone products and an oxadiazole. A solution of $400 \mu \mathrm{M}$ tetrazine 2a was prepared in PBS (with 2\% DMSO) in a cuvette. Tetrazine was stored in cuvette in ambient light at room temperature between each measurement. Tetrazine concentration was measured by recording the absorbance at $520 \mathrm{~nm}$ every $5 \mathrm{~min}$. 

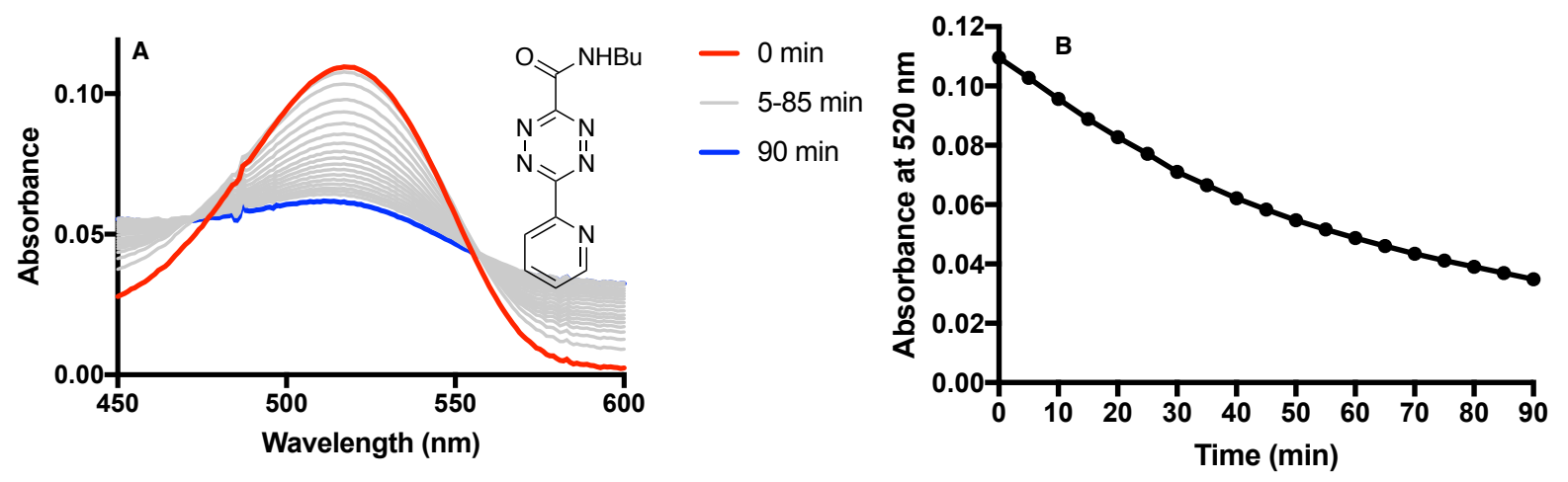

Figure S4 (A) Tetrazine 2a hydrolysis was monitored by UV-vis. (B) UV-vis absorbance of tetrazine at $520 \mathrm{~nm}$ versus time. The hydrolysis half-life of Tetrazine in PBS is $50 \mathrm{~min}$. Whole spectrum was raw data. Absorbance at $520 \mathrm{~nm}$ was after background correction of the average wavelength between $750 \mathrm{~nm}$ and $800 \mathrm{~nm}$.

\subsection{Photocatalytic oxidation of DHTz with fluorescein and blue light}<smiles>CCCCNC(=O)C1=NNC(c2ccccn2)=NN1</smiles>

1 a

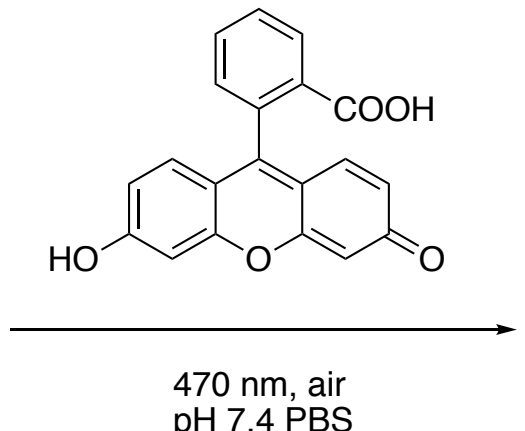

$\mathrm{pH}$ 7.4 PBS<smiles>CCCCCNC(=O)c1nnc(-c2ccccn2)nn1</smiles>

$2 a$

Solutions of $20 \mu \mathrm{M}$ DHTz 1a and $1 \mu \mathrm{M}$ fluorescein were prepared in PBS buffer at $\mathrm{pH}$

7.4. The photocatalytic oxidation of DHTz 1a was monitored by recording absorbance at $285 \mathrm{~nm}$ every second with continuous irradiation by blue light (470 nm, Fig S5). As shown in Fig S5B, absorbance at $285 \mathrm{~nm}$ ( $\lambda_{\max }$ for the tetrazine) reached a maximum after 40 seconds, and then diminished with further irradiation. 

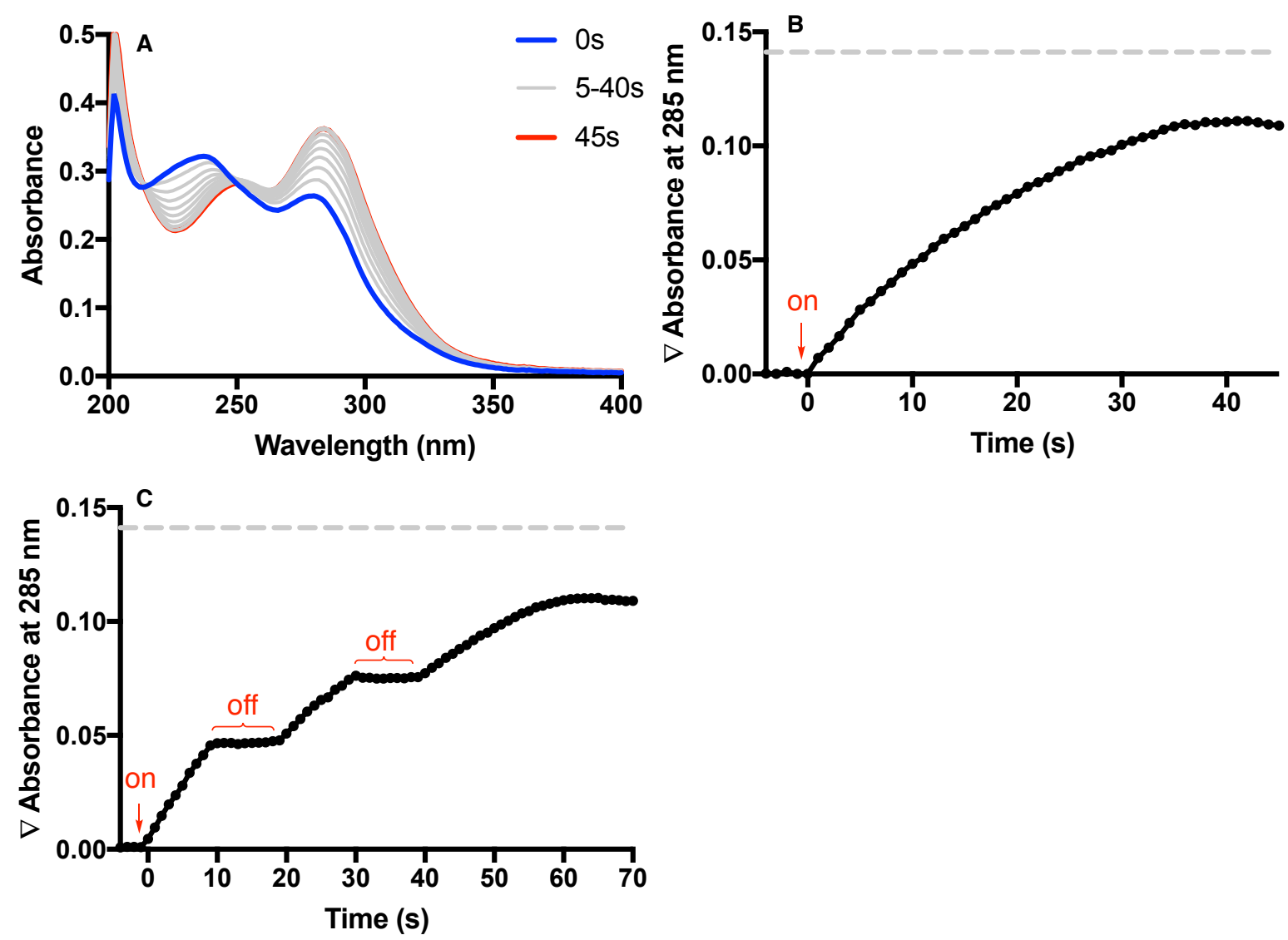

Figure S5 (A) UV-vis spectrum of photocatalytic oxidation of $20 \mu \mathrm{M}$ DHTz 1a with 1 $\mu \mathrm{M}$ fluorescein and $470 \mathrm{~nm}$ light. (B) $\Delta$ Absorbance of DHTz at $285 \mathrm{~nm}$ versus time. The grey line represents $100 \%$ oxidation to tetrazine product. (C) DHTz oxidation is light dependent.

Additional experiments were carried out to test the photostability of tetrazine 2a in the presence and absence of fluorescein and light. Solutions of $20 \mu \mathrm{M} 2 \mathbf{2 a}$ were prepared in PBS buffer at $\mathrm{pH}$ 7.4. Decomposition of the tetrazine was monitored by recording absorbance at 285 $\mathrm{nm}$ every 1 second. The UV-vis data indicated that the decomposition of tetrazine is accelerated in presence photocatalyst and light (Figure S6A), and that tetrazine is photostable in the absence of fluorescein (Figure S6B), with similar stability to what is observed in the absence of light and photocatalyst (Figure S6C). 

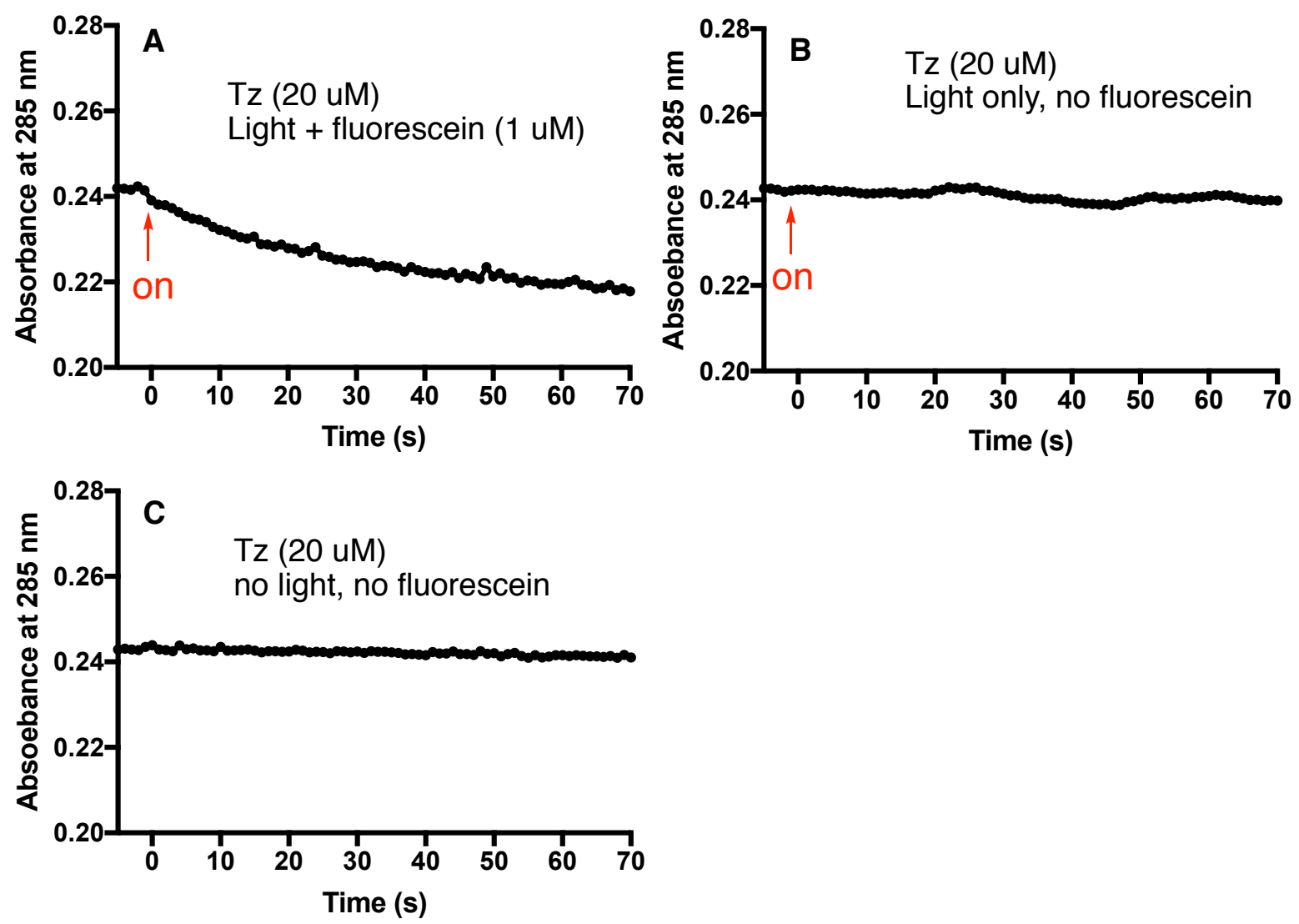

Figure S6 (A) Decomposition of $20 \mu \mathrm{M}$ tetrazine 2a with $1 \mu \mathrm{M}$ fluorescein and $470 \mathrm{~nm}$ light irradiation. (B) Decomposition of $20 \mu \mathrm{M}$ tetrazine 2a with $470 \mathrm{~nm}$ light irradiation without fluorescein. (C) Decomposition of $20 \mu \mathrm{M}$ tetrazine 2a with $1 \mu \mathrm{M}$ fluorescein without $470 \mathrm{~nm}$ light irradiation.

\subsection{Photocatalytic oxidation of DHTz with SiR-tJF 646 and red light}

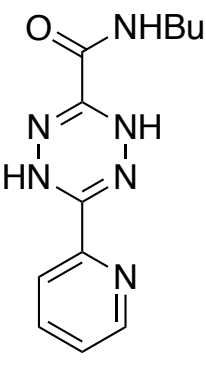

$1 \mathrm{a}$<smiles>C[Si]1(C)C2=CC(=[N+]3CCC3)C=CC2=C(c2cscc2C(=O)[O-])c2ccc(N3CCC3)cc21</smiles>

PBS pH 7.4<smiles>CCCCCNC(=O)c1nnc(-c2ccccn2)nn1</smiles>

$2 a$ 
Solutions of $25 \mu \mathrm{M}$ DHTz $1 \mathrm{a}$ and $1 \mu \mathrm{M}$ SiR dye thienyl $\mathrm{JF}_{646}\left(\mathrm{SiR}_{-1 J F} 646\right)^{1}$ were prepared in PBS buffer at $\mathrm{pH}$ 7.4. Photocatalytic oxidation of DHTz was monitored by recording absorbance at $285 \mathrm{~nm}$ every 10 seconds with continuous irradiation of red light $(660 \mathrm{~nm}, 450$ $\left.\mathrm{mW} / \mathrm{cm}^{2}\right)$.
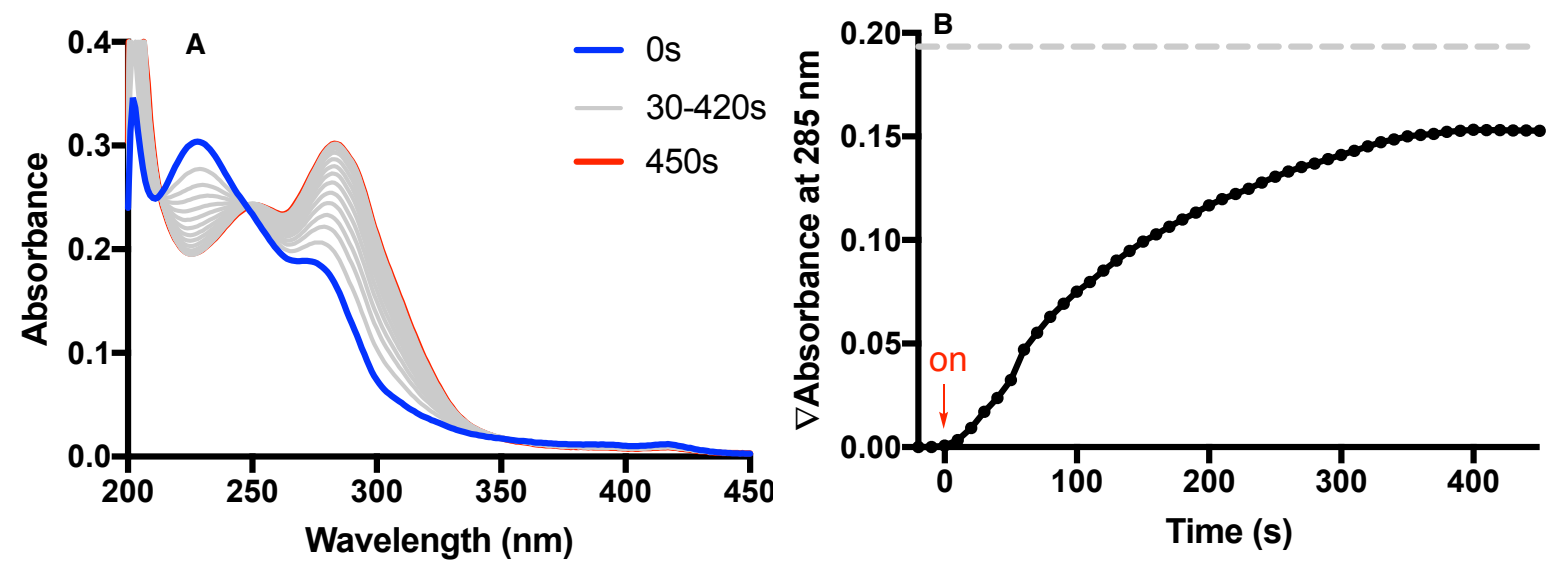

Figure S7 UV-vis spectrum of photocatalytic oxidation of $25 \mu \mathrm{M}$ DHTz 1a with $1 \mu \mathrm{M}$ SiR-tJF 646 and $660 \mathrm{~nm}$ light. (B) $\triangle$ Absorbance of DHTz at $285 \mathrm{~nm}$ versus time. Grey line indicated $100 \%$ oxidation. 


\subsection{Reduction/Degradation and Reoxidation of Tetrazines in Glutathione}

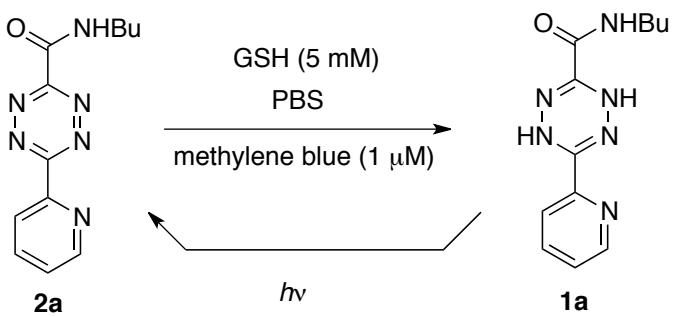

In order to evaluate the effects of cellular concentrations of glutathione on tetrazine, a solution of $150 \mu \mathrm{M} 2 \mathrm{a}$ was prepared in a cuvette, along with $1 \mu \mathrm{M}$ methylene blue and $5 \mathrm{mM}$ of glutathione ( $\mathrm{pH}$ adjusted to 7.6) in PBS. The concentration of tetrazine was monitored at $520 \mathrm{~nm}$ every 5 seconds by UV-vis at room temperature in ambient light. After the Tetrazine peaks reached their lowest point, $660 \mathrm{~nm}$ light was applied to the cuvette, and the subsequent reoxidation and degradation/reduction was once again monitored by UV-vis.

The half-life for the disappearance of the tetrazine was 70 seconds. Photocatalytic oxidation allowed for the recovery of $65 \%$ of the tetrazine absorbance, suggesting that dihydrotetrazine 1a is major product, with the remainder lost to nucleophilic attack by GSH and/or water.
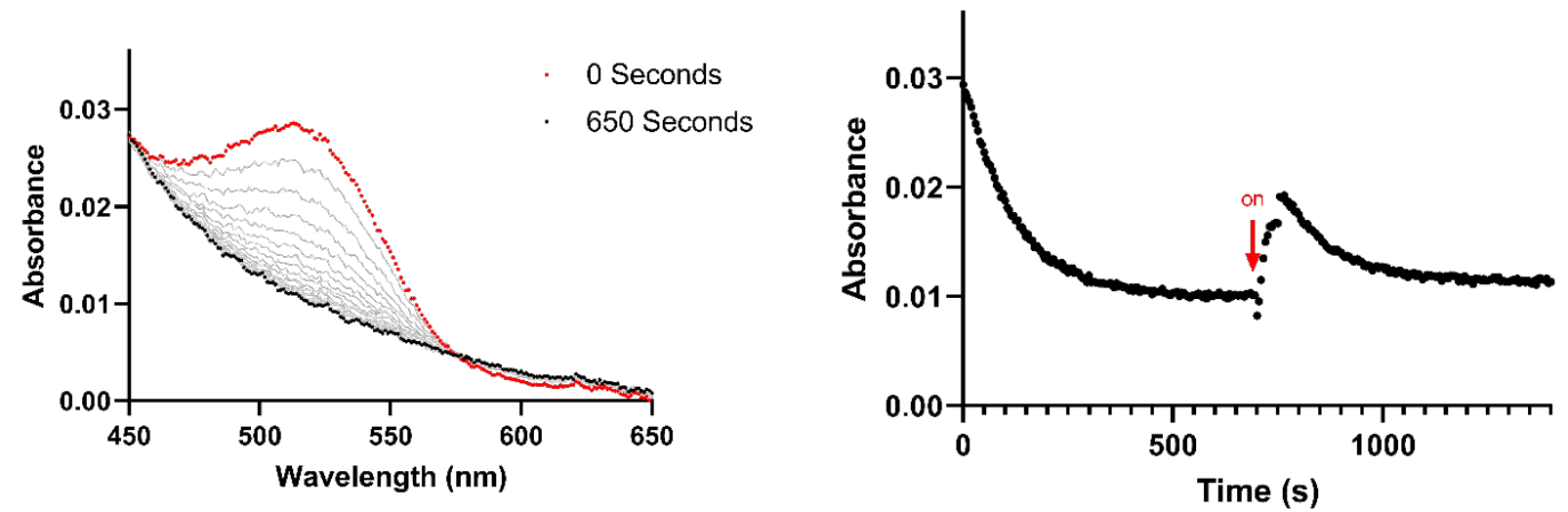

Figure S7A (A) UV-vis spectrum of $150 \mu \mathrm{M}$ Tetrazine 2a in the presence of $5 \mathrm{~mm}$ glutathione and $1 \mu \mathrm{M}$ methylene blue. (B) Absorbance of tetrazine at $520 \mathrm{~nm}$ versus time. Turning the light on caused partial recovery of absorbance at $520 \mathrm{~nm}$.

\subsection{Reduction/Degradation and Reoxidation of Tetrazines in Cell Lysate}

A $400 \mu \mathrm{M}$ solution of tetrazine $\mathbf{2 a}$ was prepared in a cuvette in containing HeLa cell lysate (diluted to $0.5 \mathrm{mg} / \mathrm{mL}$ total protein concentration) along with $1 \mu \mathrm{M}$ methylene blue. The concentration of tetrazine was monitored at $520 \mathrm{~nm}$ every 5 seconds by UV-vis at room temperature in ambient light. After 100 minutes, $660 \mathrm{~nm}$ light was applied to the cuvette, and the subsequent reoxidation and degradation/reduction was once again monitored by UV-vis. The half-life for the disappearance of the tetrazine was determined to be 33 minutes, and the absorbance at $520 \mathrm{~nm}$ was able to be partially recovered upon irradiation, likely due to the reoxidation of $1 \mathbf{a}$ that was formed by the reduction of $\mathbf{2 a}$ by cellular glutathione. 

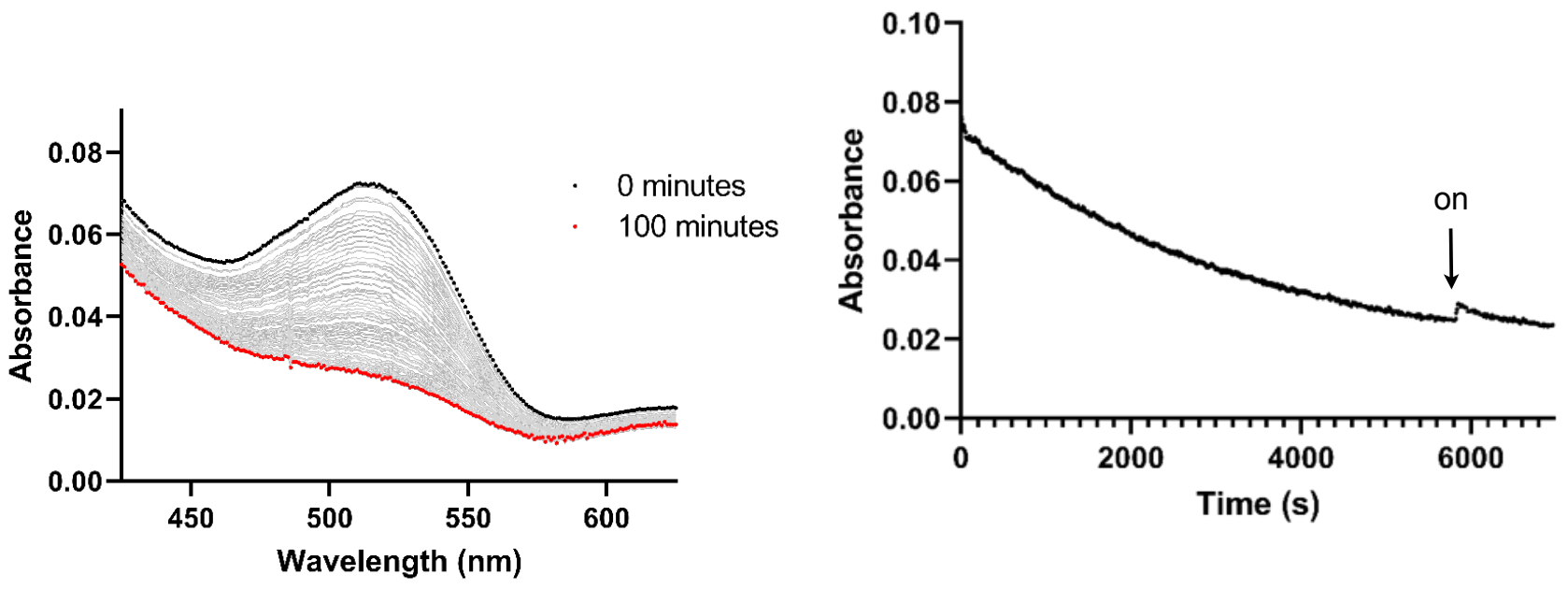

Figure S7B (A) UV-vis spectrum of $150 \mu \mathrm{M}$ tetrazine 2a in the presence of $5 \mathrm{~mm}$ glutathione and $1 \mu \mathrm{M}$ methylene blue. (B) Absorbance of tetrazine at $520 \mathrm{~nm}$ versus time. Turning the light on at caused partial recovery of absorbance at $520 \mathrm{~nm}$.

\subsection{Photocatalytic Oxidation/Diels-Alder Reaction of DHTz 1a with BCN}

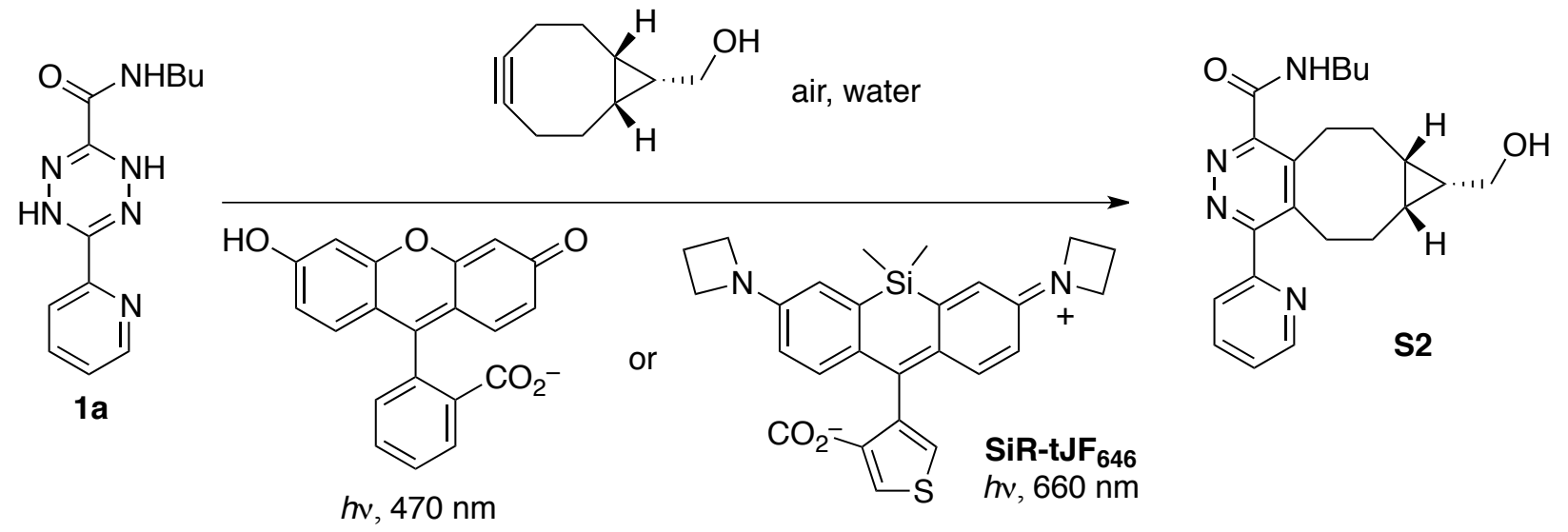

HPLC calibration curves were developed for $\mathbf{1 a}$ and Diels-Alder adduct $\mathbf{S 2}$ vs caffeine, which was used as an internal standard. Solutions of 10, 20, 25, 30 and $40 \mu \mathrm{M}$ DHTz 1a with $10 \mu \mathrm{M}$ caffeine were prepared in LCMS grade water and injected onto the HPLC. Similarly, solutions of $10,20,25,30$ and $40 \mu \mathrm{M}$ of $\mathbf{S 2}$ with $10 \mu \mathrm{M}$ caffeine were prepared in LCMS grade water and injected onto the HPLC. HPLC analyses were carried out with the following method: 0-6 min 5$95 \% \mathrm{ACN}$ in water, 6-7 $\min 95 \% \mathrm{ACN}$ in water, $7-8 \min 95-5 \% \mathrm{ACN}$ in water, $8-9 \mathrm{~min} 5 \%$ ACN in water. The injection volume of each sample was $100 \mu \mathrm{L}$, and the wavelength used for integration was $260 \mathrm{~nm}$. Areas were measured and plotted to develop the calibration curves 
displayed below. Relative to the caffeine standard, the response factor for DHTz $1 \mathbf{a}$ is $0.73 \pm .02$ and the response factor for Diels-Alder adduct $\mathbf{S 2}$ is $0.66 \pm .01$. For analyses of DHTz 1a, it was noted that $\sim 3 \%$ oxidation to tetrazine 2 a occurred upon HPLC injection.
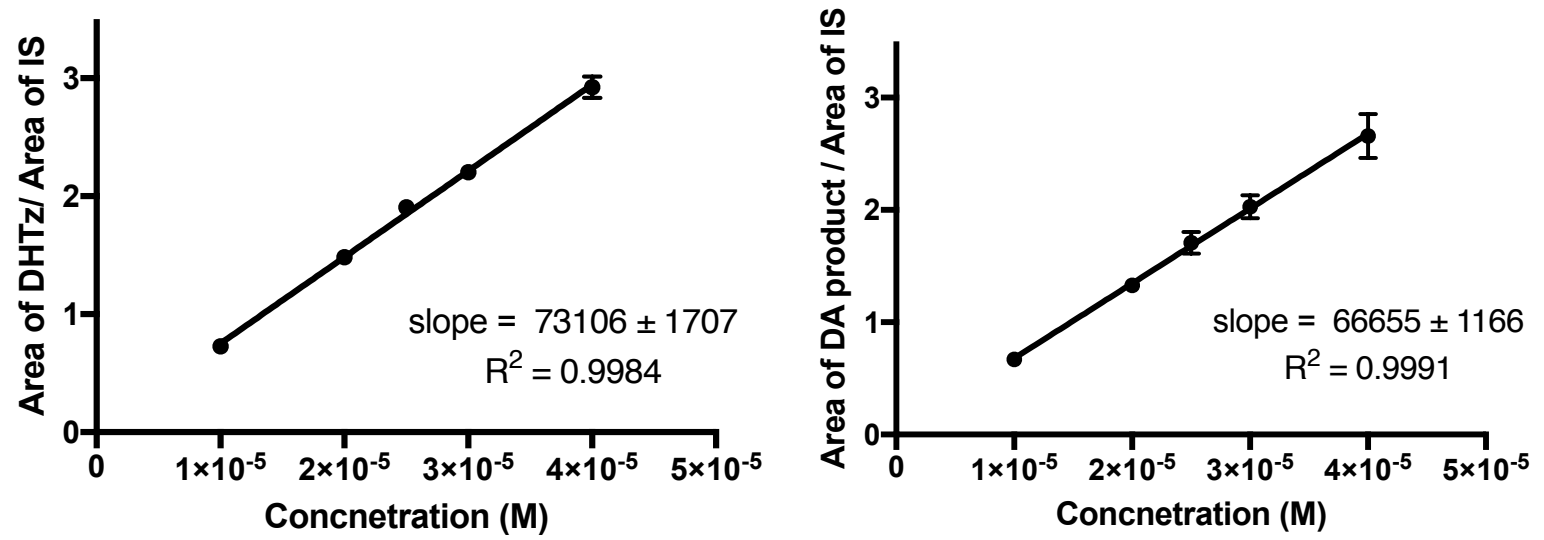

Calibration Curves: HPLC calibration curves for DHTz 1a (left) and Diels-Alder adduct S2 (right) relative to $10 \mu \mathrm{M}$ of caffeine, used as an internal standard (IS).

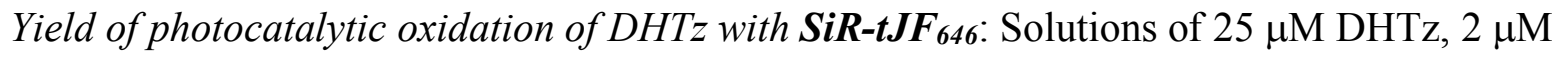

SiR-tJF $\mathbf{6 4 6}^{1}, 50 \mu \mathrm{M}$ BCN and $10 \mu \mathrm{M}$ caffeine were prepared in LCMS grade water and injected into the HPLC using the same method and injection volume as was used in the calibration to determine the initial concentration of DHTz. After red light $\left(660 \mathrm{~nm}, 450 \mathrm{~mW} / \mathrm{cm}^{2}\right)$ irradiation for 10 minutes, the solution was injected into the HPLC to determine the concentration of DielsAlder adduct S2.

Yield of photocatalytic oxidation of DHTz with fluorescein: Solutions of $25 \mu \mathrm{M} \mathrm{DHTz,} 2 \mu \mathrm{M}$ fluorescein, $50 \mu \mathrm{M}$ BCN and $10 \mu \mathrm{M}$ caffeine was prepared in LCMS grade water and injected into HPLC using the same method and injection volume as was used in the calibration to determine the initial concentration of DHTz. After blue light (470 nm) irradiation for 45 seconds, the solution was injected into the HPLC to determine the concentration of Diels-Alder adduct S2 


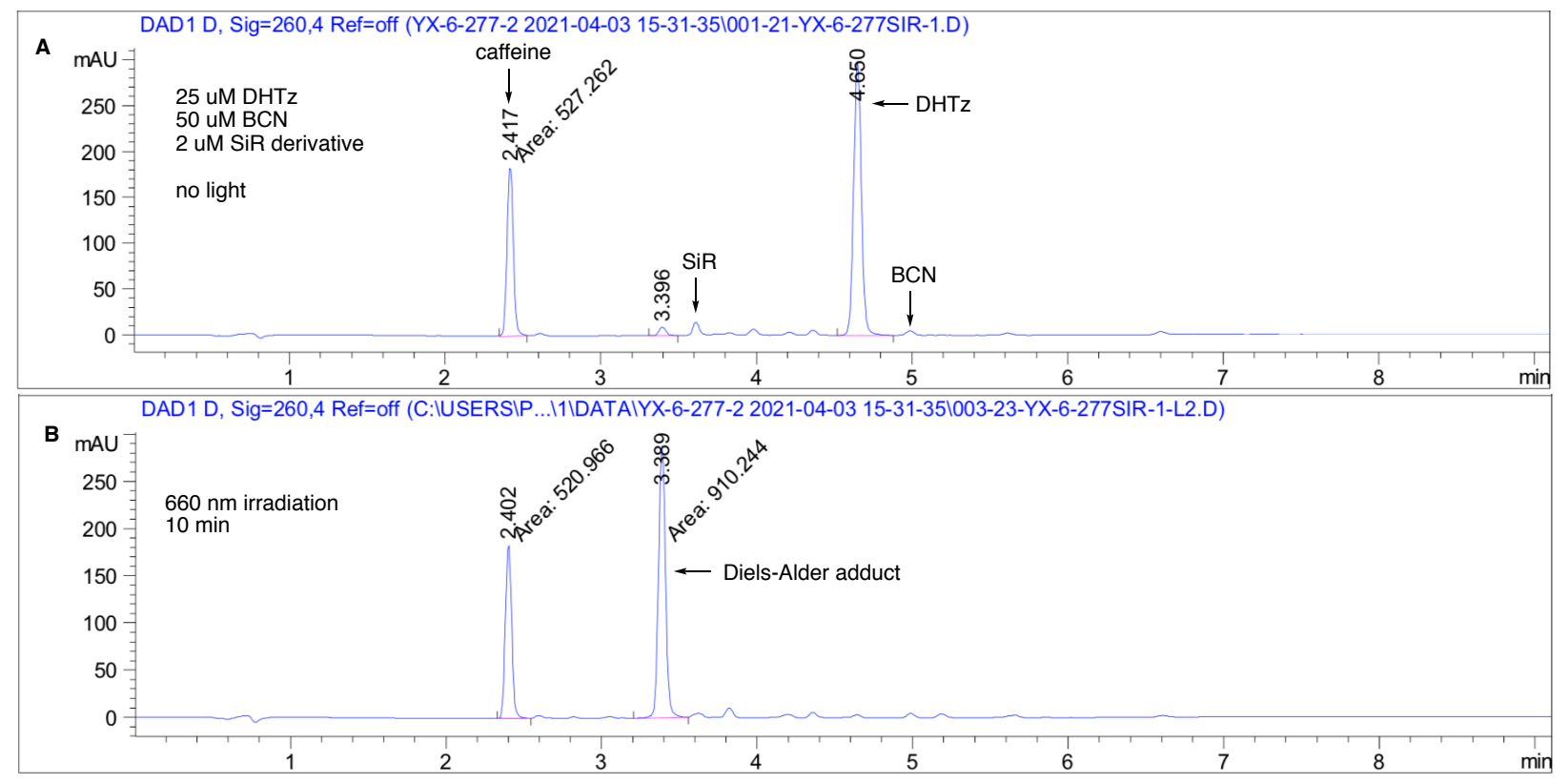

Figure S8 HPLC monitored by $260 \mathrm{~nm}$ DAD signal (A) $25 \mu \mathrm{M}$ DHTz, $50 \mu \mathrm{M}$ BCN, 2 $\mu \mathrm{M}$ SiR-tJF 646 and $10 \mu \mathrm{M}$ caffeine without light irradiation (B) After red light irradiation (660 $\mathrm{nm}, 450 \mathrm{~mW} / \mathrm{cm}^{2}$ ) for 10 minutes. The yield of DHTz with SiR-tJF 646 photocatalysis was $98 \pm$ $1 \%$.

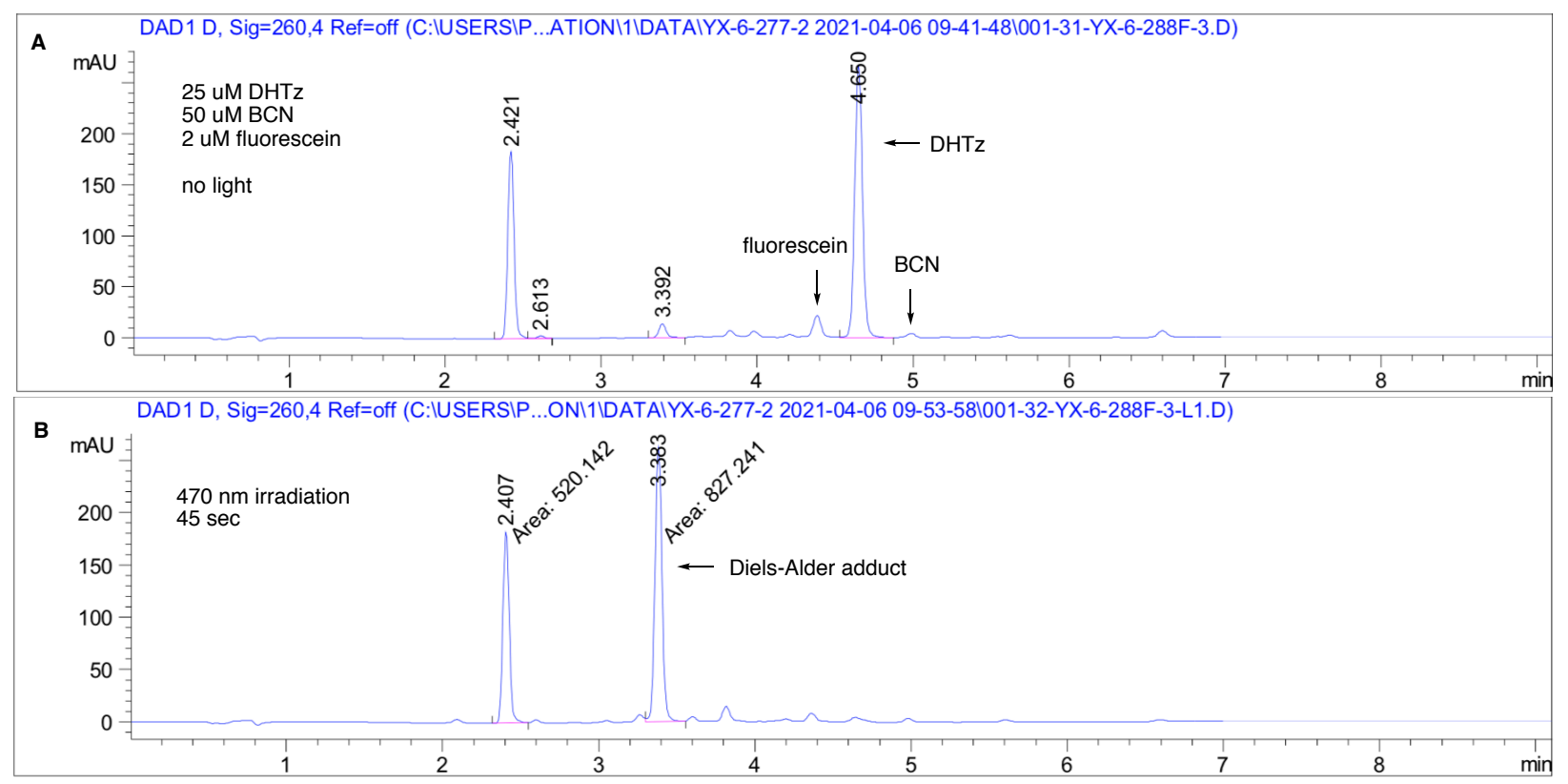

Figure S9 HPLC results monitored by $260 \mathrm{~nm}$ DAD signal (A) $25 \mu \mathrm{M}$ DHTz, $50 \mu \mathrm{M}$

$\mathrm{BCN}, 2 \mu \mathrm{M}$ fluorescein and $10 \mu \mathrm{M}$ caffeine without light irradiation (B) After blue light 
irradiation for 45 seconds $(470 \mathrm{~nm})$. Yield of photocatalytic oxidation of DHTz with fluorescein is $96 \pm 2 \%$.

\subsection{Kinetic Measurements for Reactions of Tetrazines and trans-Cyclooctenes}

Solutions $(5 \mathrm{~mL})$ of Tetrazines were prepared in PBS buffer $(\mathrm{pH} 7.4)$ or $\mathrm{MeOH}$.

Solutions (10 mL) of equatorial-5-hydroxy-trans-cyclooctene, a-TCO, o-TCO or s-TCO (5-12

equiv.) were prepared in PBS buffer ( $\mathrm{pH} 7.4)$ or $\mathrm{MeOH}$. The reactions between tetrazines and trans-cyclooctenes were measured under pseudo-first order conditions using SX 18MV-R stopped-flow spectrophotometer (Applied Photophysics Ltd.). Solutions of tetrazine and transcyclooctene derivative were injected in equal volumes via $3 \mathrm{~mL}$ syringes into the stopped-flow instrument at $25{ }^{\circ} \mathrm{C}$, resulting in final concentration that was half of the prepared solutions. The reaction was monitored by the decay of absorbance associated with the tetrazines at maximum absorbance wavelength. Reactions were repeated in triplicate. With Prism software, an observed rate constant, $\mathrm{k}_{\mathrm{obs}}$, was obtained by nonlinear regression. Second order rate constants, $\mathrm{k}_{2}$, were calculated by linear regression between $\mathrm{k}_{\mathrm{obs}}$ and final concentration of TCOs. 

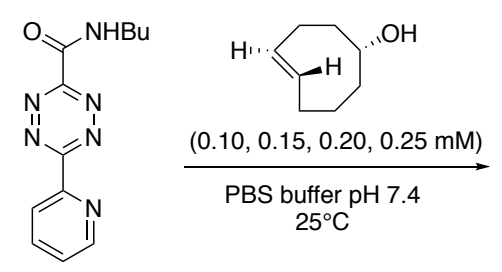

$0.020 \mathrm{mM}$
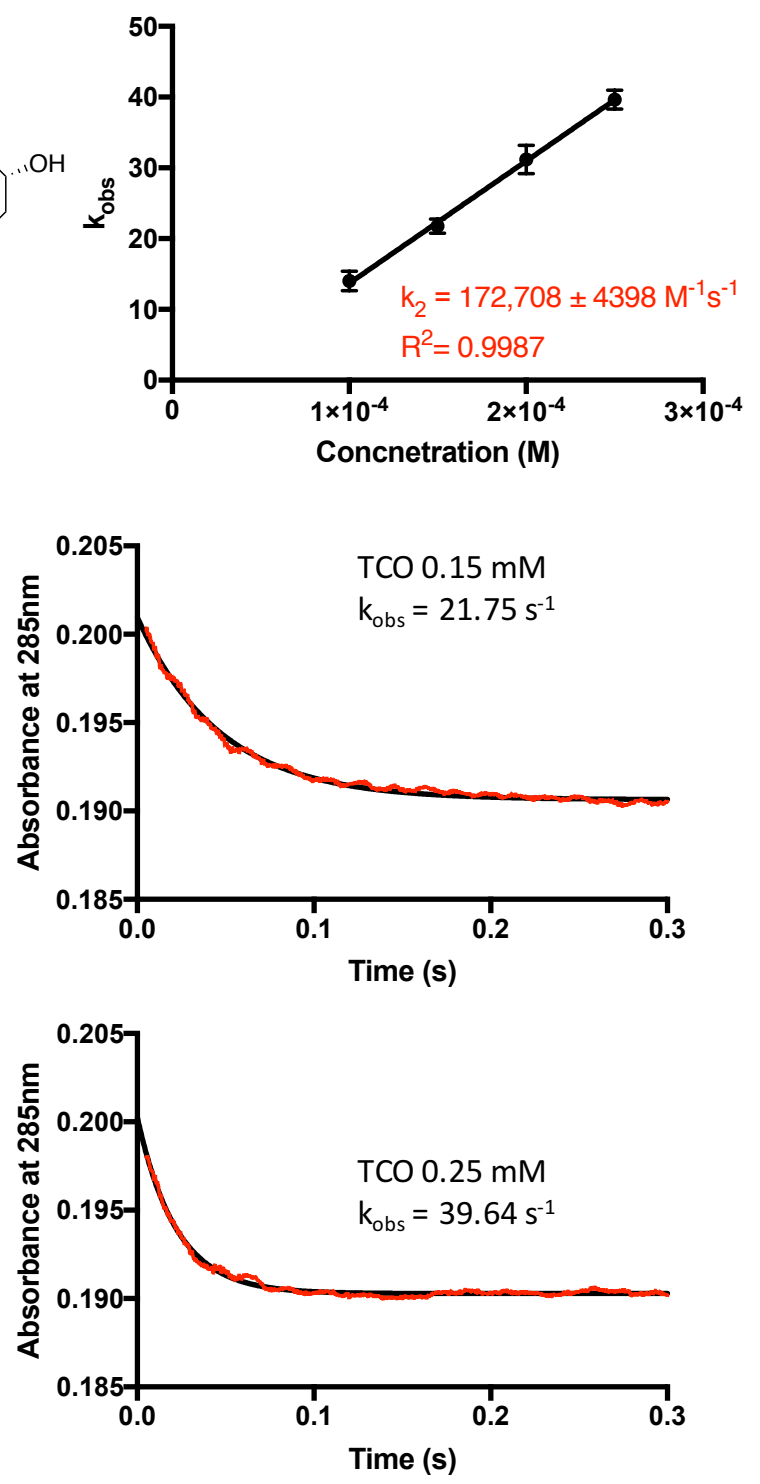

Figure S10 Pseudo-first order stopped-flow kinetics of tetrazine 2a and eq-5-hydroxy-transcyclooctene in PBS. The plot shows the decay of absorbance at $285 \mathrm{~nm}$ measured by a stoppedflow instrument (red curve). The nonlinear regression calculation by prism software is fitted as black curve. Triplicate $\mathrm{k}_{\mathrm{obs}}$ results are shown on plot of $\mathrm{k}_{\mathrm{obs}}$ across four different concentrations of TCO. The second-order rate constant $\mathrm{k}_{2}$ was calculated using Prism software. 


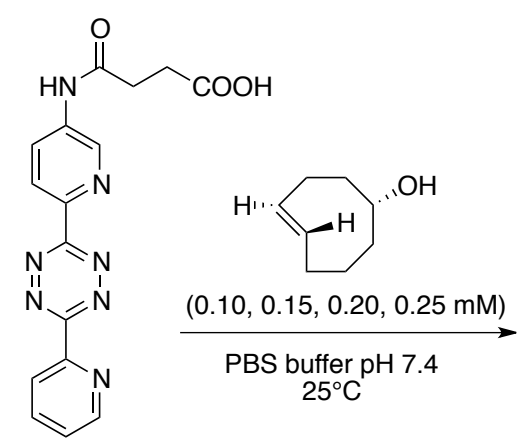

$(0.020 \mathrm{mM})$
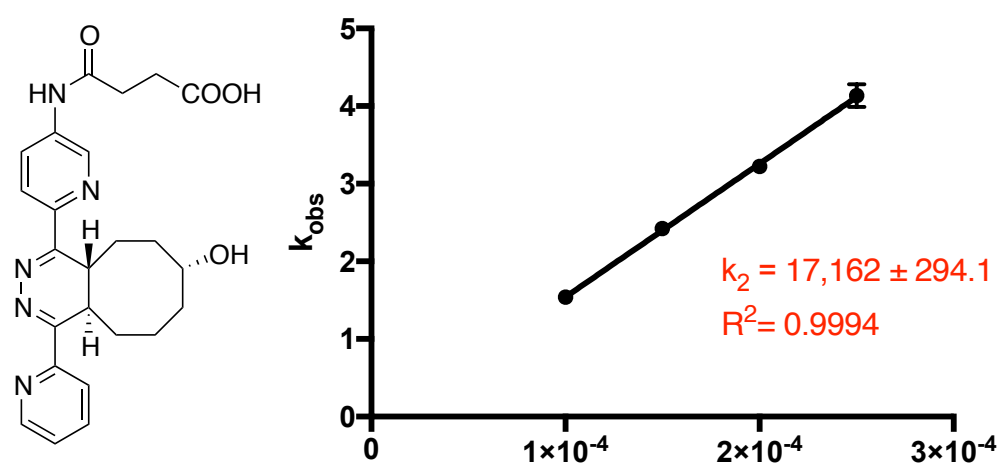

Concnetration (M)
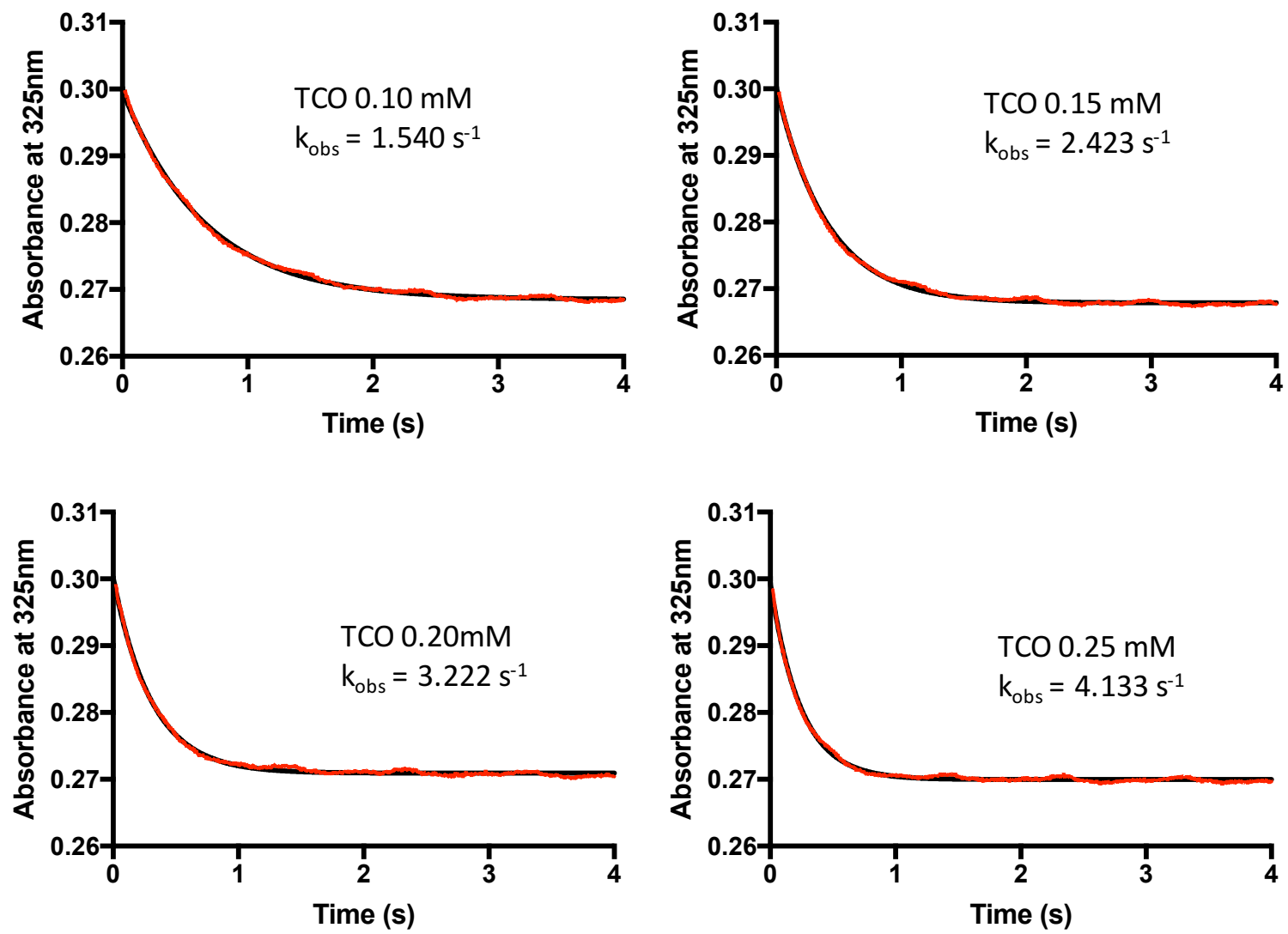

Figure S11 Pseudo-first order stopped-flow kinetics of 3,6-dipyridyltetrazine succinamic acid and eq-5-hydroxy-trans-cyclooctene in PBS. The plot shows the decay of absorbance at $325 \mathrm{~nm}$ measured by a stopped-flow instrument (red curve). The nonlinear regression calculation by prism software is fitted as black curve. Triplicate $k_{o b s}$ results are show on plot of $k_{\text {obs }}$ across four different concentrations of TCO. The second-order rate constant $\mathrm{k}_{2}$ was calculated using Prism software. 

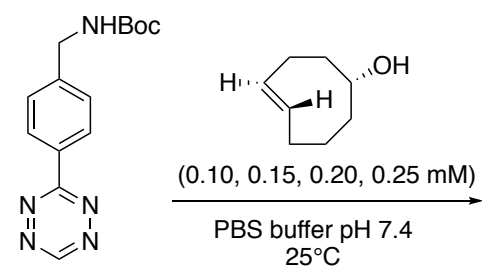

$(0.020 \mathrm{mM})$
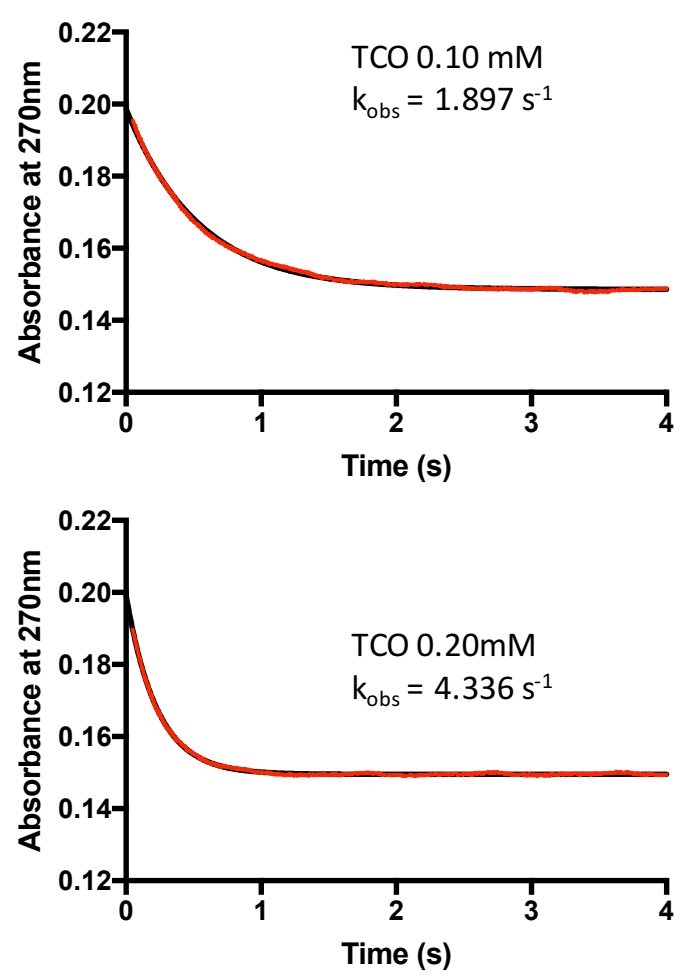
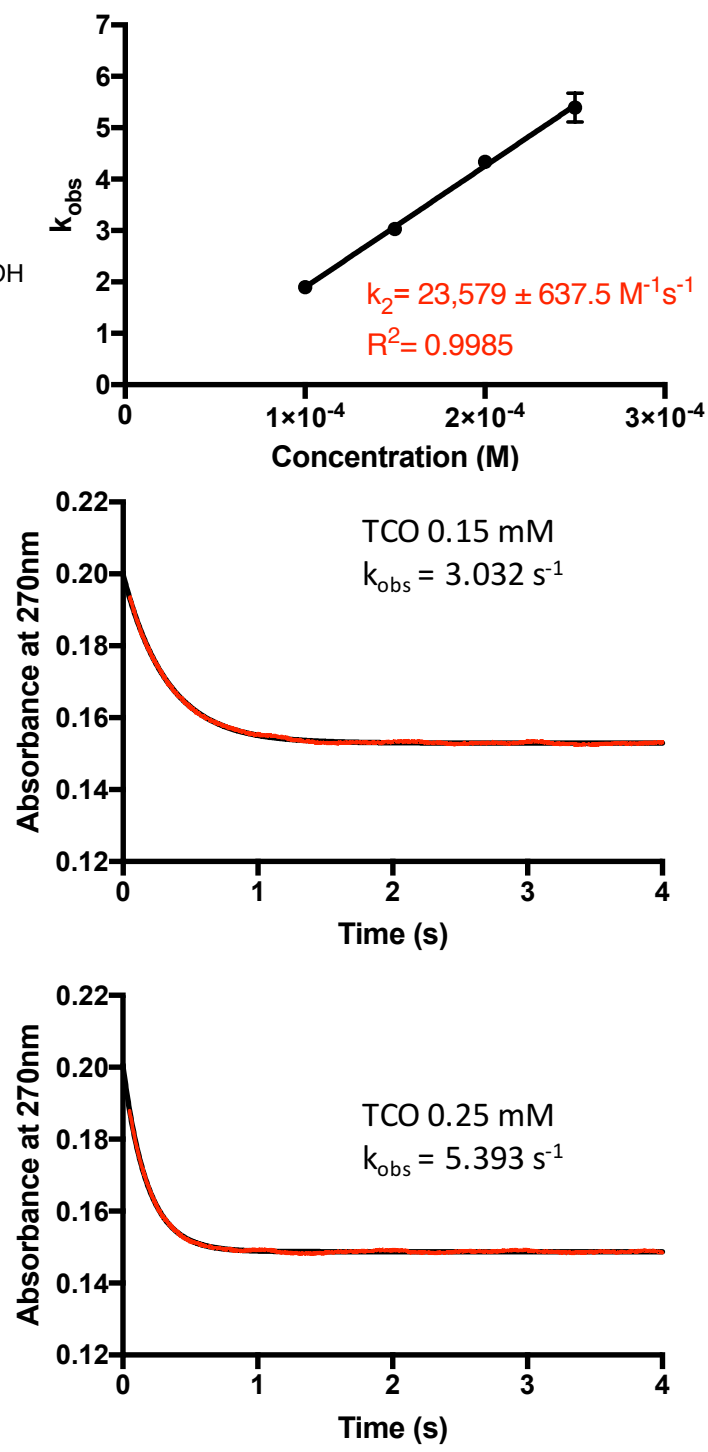

Figure S12 Pseudo-first order stopped-flow kinetics of a monophenyltetrazine derivative and eq5-hydroxy-trans-cyclooctene in PBS. The plot shows the decay of absorbance at $270 \mathrm{~nm}$ measured by a stopped-flow instrument (red curve). The nonlinear regression calculation by prism software is fitted as black curve. Triplicate $\mathrm{k}_{\mathrm{obs}}$ results are show on plot of $\mathrm{k}_{\mathrm{obs}}$ across four different concentrations of TCO. The second-order rate constant $\mathrm{k}_{2}$ was calculated using Prism software. 

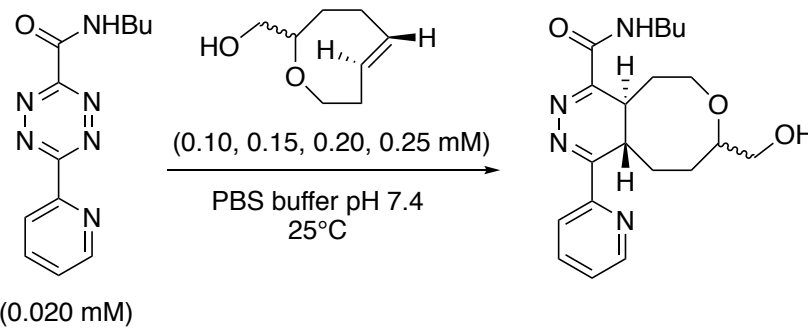

(0.020 mM)
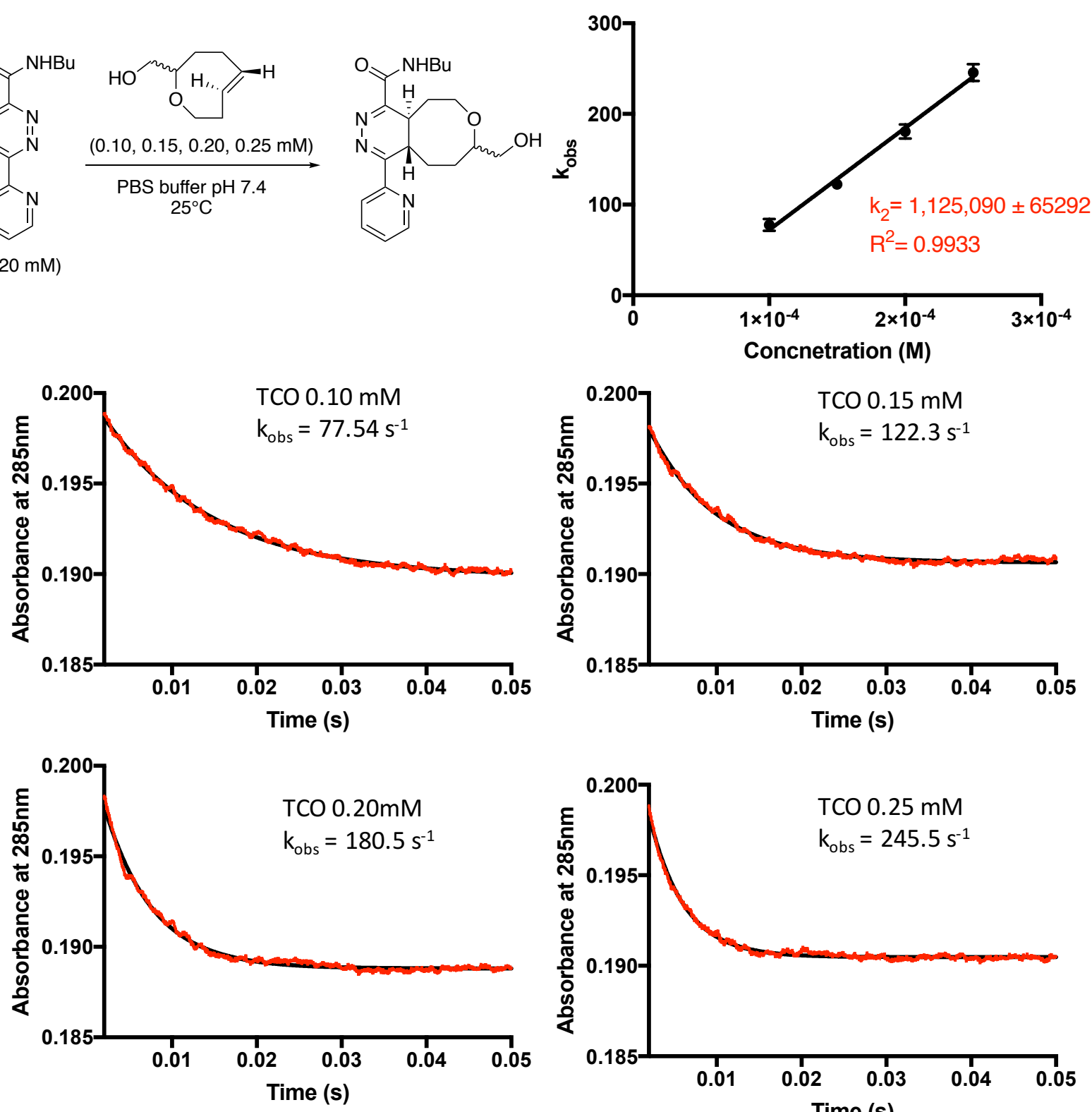
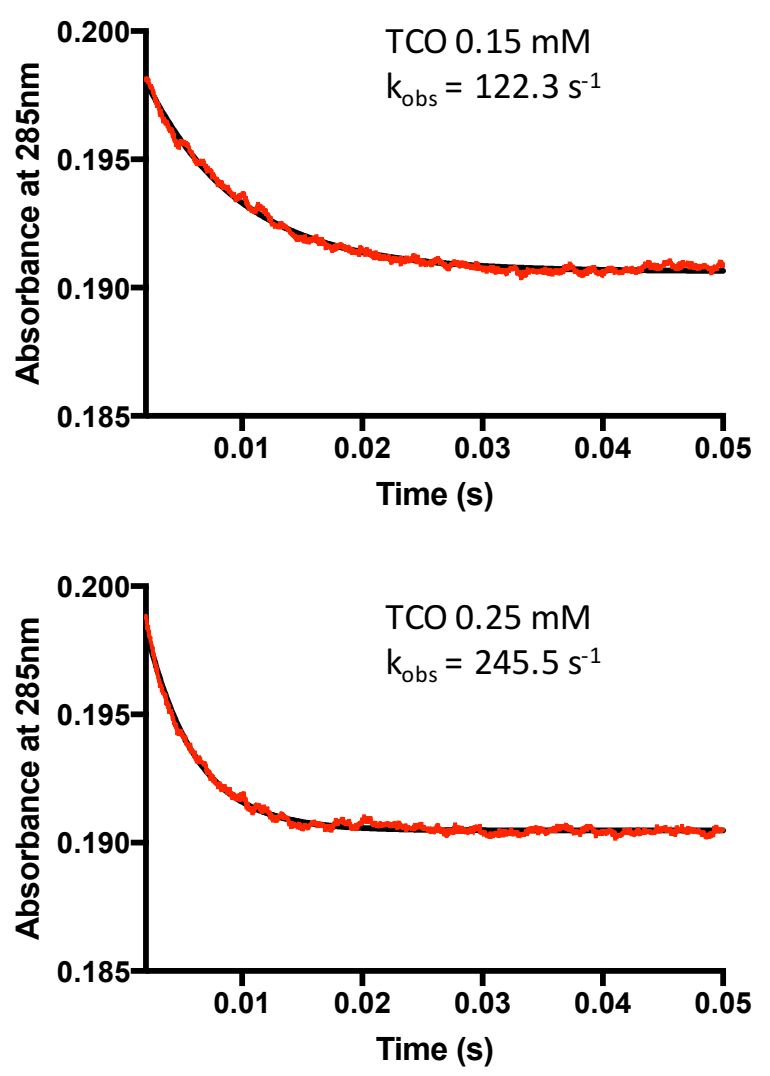

Figure S13 Pseudo-first order stopped-flow kinetics of tetrazine 2a and oTCO

(equatorial:axial 2.6:1) in PBS. The plot shows the decay of absorbance at $285 \mathrm{~nm}$ measured by a stopped-flow instrument (red curve). The nonlinear regression calculation by prism software is fitted as black curve. Triplicate $\mathrm{k}_{\text {obs }}$ results are show on plot of $\mathrm{k}_{\text {obs }}$ across four different concentrations of TCO. Second-order rate constant $\mathrm{k}_{2}$ was calculated by prism software. 

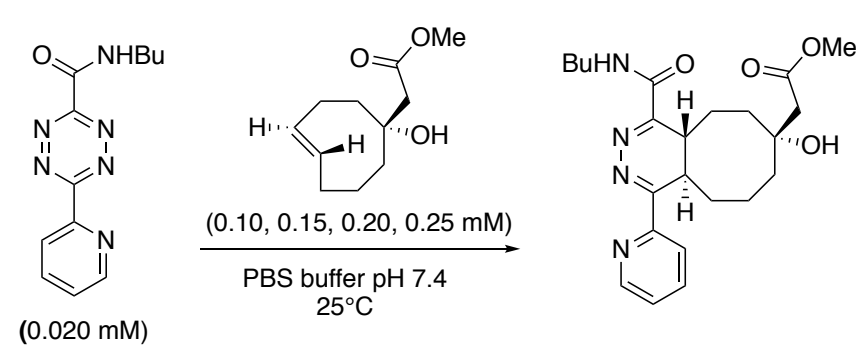
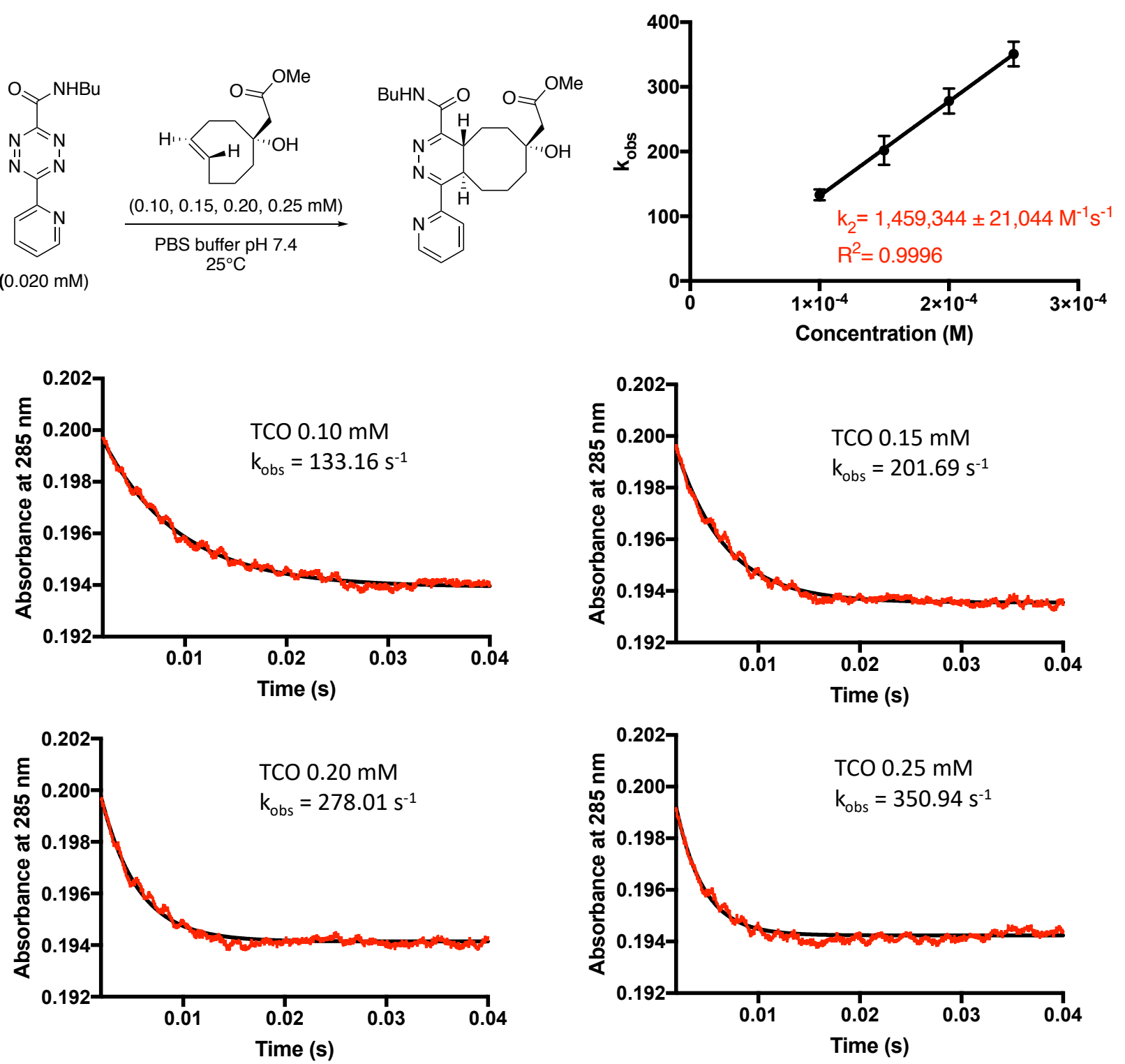

Figure S14 Pseudo-first order stopped-flow kinetics of tetrazine 2a and aTCO in PBS. The plot shows the decay of absorbance at $285 \mathrm{~nm}$ measured by a stopped-flow instrument (red curve). The nonlinear regression calculation by prism software is fitted as black curve. Triplicate $\mathrm{k}_{\mathrm{obs}}$ results are show on plot of $\mathrm{k}_{\mathrm{obs}}$ across four different concentrations of TCO. The second-order rate constant $\mathrm{k}_{2}$ was calculated using Prism software. 

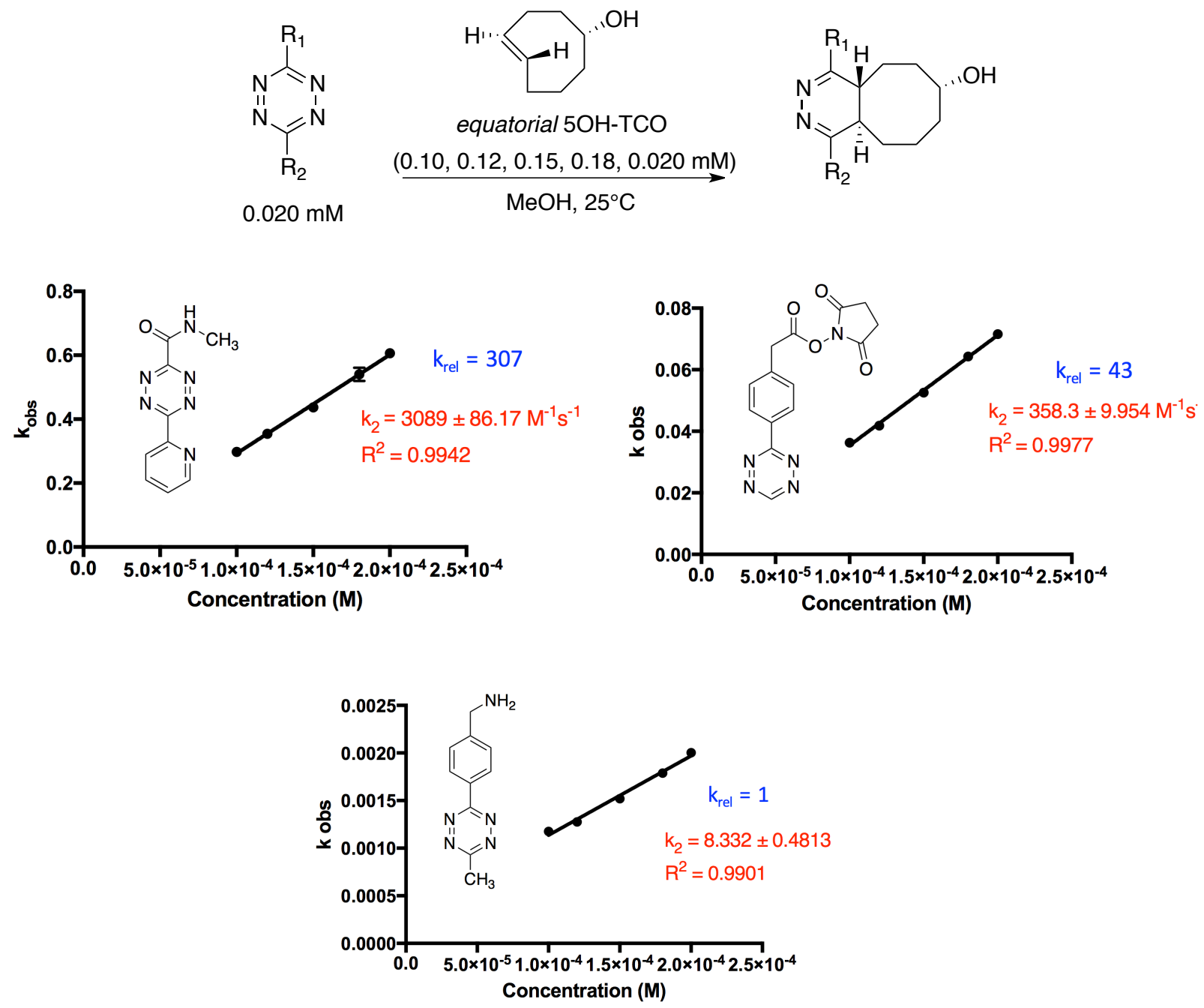

Figure S15 Kinetics comparison of three Tetrazines using eq-5-OH-TCO in $\mathrm{MeOH}$.

Pseudo-first order stopped-flow kinetics of tetrazines and eq-5-OH-TCO in $\mathrm{MeOH}$ was measured. $k_{\text {obs }}$ results are calculated by prism software for four different concentrations of TCO. Second-order rate constant $\mathrm{k}_{2}$ was calculated. $\mathrm{k}_{\text {rel }}$ indicates relative rate. 


\section{1: Plasmids:}

Halo-H2B-GFP and Halo-GAP43-GFP plasmids were gifts from Pfizer. ${ }^{3}$ Halo-mito-GFP was a gift from Michael Lampson (Addgene plasmid \# 67762 ; http://n2t.net/addgene:67762 ;

RRID:Addgene_67762). To create a HaloTag construct for bacterial expression, a HaloTag vector (purchased from Promega) was cut with BamHI/ EcoRI and inserted into a pET28a vector containing an H6-TEV tag, yielding H6-TEV-Halotag. To create LifeAct-Halo-GFP, a HaloGFP fragment was created by PCR amplification of Halo-mito-gfp. LifeAct-EGFP (a gift from Dyche Mullins (Addgene plasmid \# 58470 ; http://n2t.net/addgene:58470 ; RRID:Addgene_58470)) was cut with BamHI/NotI, and the resulting fragment was ligated onto Halo-GFP.

\section{1: H6-TEV-Halotag Protein Expression and Purification}

BL21 cells expressing the H6-TEV-Halotag protein were inoculated 1:500 from an overnight starter culture $(4 \mathrm{~mL})$ into $2 \mathrm{~L}$ of TB broth containing $50 \mu \mathrm{g} / \mathrm{uL}$ Kanamycin and incubated at 37 ${ }^{\circ} \mathrm{C}$. When an $\mathrm{OD}_{600}$ of $0.6-0.8$ was reached the cells were induced with $1 \mathrm{mM}$ IPTG and allowed to express at $16^{\circ} \mathrm{C}$ for 16 hours. The cells were then harvested by centrifugation at $3,000 \mathrm{~g}$ for 10 minutes at $4{ }^{\circ} \mathrm{C}$ and resuspended in a minimal amount of wash buffer $(50 \mathrm{mM}$ sodium phosphate, $200 \mathrm{mM}$ sodium chloride, $30 \mathrm{mM}$ imidazole, $\mathrm{pH}$ 7.5) and mechanically lysed by passing through a French press. The lysate was sonicated for 30 seconds over ice to shear DNA before being clarified by centrifugation at 20,000x g for 20 minutes at $4{ }^{\circ} \mathrm{C}$. The supernatant was loaded onto a Ni-IDA resin column. The lysate was washed with 10 column volumes of wash buffer and eluted with 10 column volumes of elution buffer $(50 \mathrm{mM}$ sodium phosphate, $200 \mathrm{mM}$ sodium chloride, $400 \mathrm{mM}$ imidazole, $\mathrm{pH}$ 7.5). Fractions containing eluted protein were identified via SDS-PAGE, then dialyzed against a solution of $25 \mathrm{mM}$ tris buffer (pH 8.0), $200 \mathrm{mM}$ sodium chloride, and $5 \mathrm{mM}$ dithiothreitol (DTT) at $4{ }^{\circ} \mathrm{C}$ under gentle stirring. Buffer was exchanged twice in 2 hour increments. During the second buffer exchange, TEV protease was added to the eluted protein, which was then allowed to react and dialyze overnight. After TEV cleavage was complete, the protein was dialyzed against $25 \mathrm{mM}$ tris buffer (pH 8.0) and $200 \mathrm{mM}$ sodium chloride for an additional 4 hours. To remove TEV protease and HIS $_{6}$ impurities, the protein was loaded onto a Ni-IDA resin column and washed with $25 \mathrm{mM}$ tris buffer (pH 8.0) and $200 \mathrm{mM}$ sodium chloride. The flow through was collected and the protein was concentrated using an Amicon 10k filter. SDS-PAGE analyses showed that the purity was $\geq 95 \%$.

\section{2: PBS/DPBS Treatment with Chelex resin}

A $50 \mathrm{~mL}$ column prerinsed with twice with $2 \mathrm{mM}$ EDTA and MQ water was filled with BioRad chelex 100 resin beads. The column was rinsed for 1 column volume with MQ water, then for 1 column volume with (D)PBS. Buffer was then added to the resin and collected in an EDTA rinsed container. $\mathrm{pH}$ was adjusted after collection, using MQ water acid/base solutions, and buffer was stored at $4{ }^{\circ} \mathrm{C}$.

\section{3: HaloTag DHTz Conjugation:}

HaloTag protein $(10 \mu \mathrm{M}$ in metal-free PBS) was incubated with $20 \mu \mathrm{M} \mathrm{1c}$ for 40 minutes at 4 ${ }^{\circ} \mathrm{C}$. The resulting protein conjugate was then desalted twice using an Amicon Ultra- $0.5 \mathrm{~mL}$ 
Centrifugal Filter, and mass spectrometry (Waters Xevo G2-S QTof) was used to confirm the formation of HaloTag-DHTz.

To a $10 \mu \mathrm{M}$ solution of Halo-DHTz was added $2.5 \mu \mathrm{M}$ fluorescein, $20 \mu \mathrm{M}$ a-TCO-TAMRA, and $5 \mathrm{mM}$ methionine. The solution was then irradiated with $470 \mathrm{~nm}$ light $\left(60 \mathrm{~mW} / \mathrm{cm}^{2}\right)$ for 60 seconds, then quenched with $125 \mu \mathrm{M}$ (4-(6-methyl-1,2,4,5-tetrazin-3-yl)phenyl)methanamine and analyzed on a Waters Xevo G2-S QTof to confirm formation of $\mathbf{1 1}$ (Fig. 3B).

A

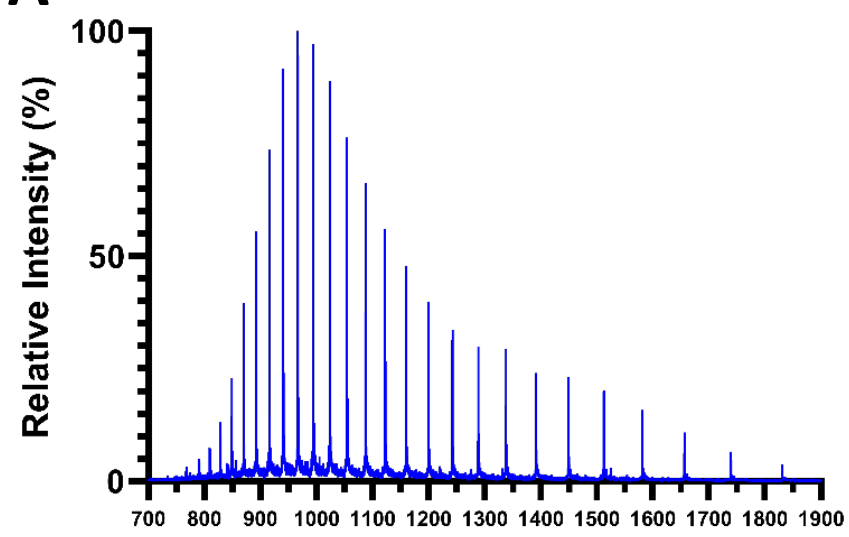

$\mathbf{m} / \mathbf{z}$

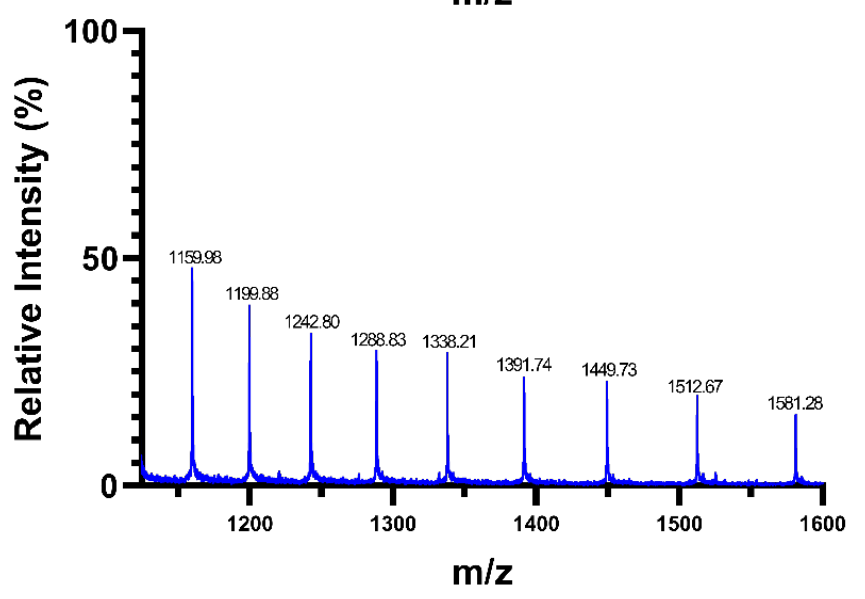

B
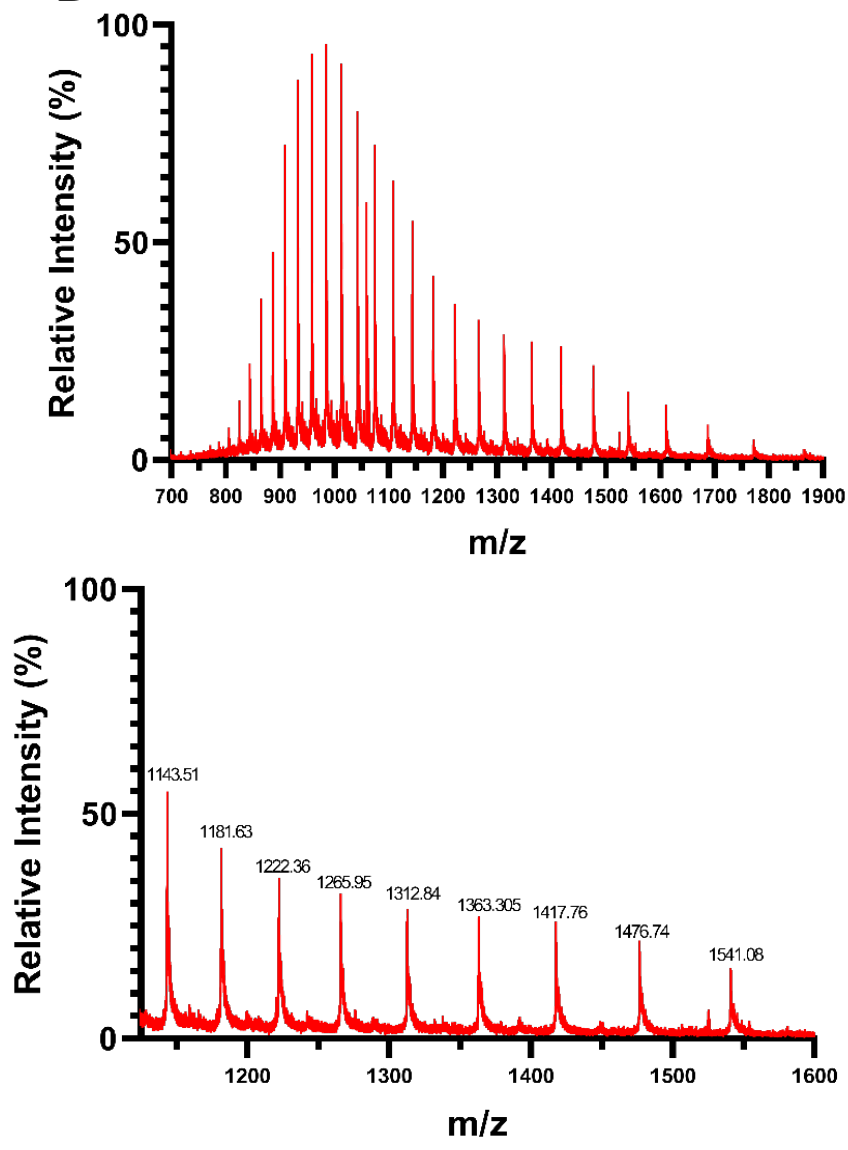

Figure S16: MS/MS of HaloTag protein conjugated to $1 \mathrm{c}$ in solution with $2.5 \mu \mathrm{M}$ fluorescein, $20 \mu \mathrm{M}$ a-TCO-TAMRA, and $5 \mathrm{mM}$ methionine before (A) and after (B) 60 seconds of irradiation with $470 \mathrm{~nm}$ light $\left(60 \mathrm{~mW} / \mathrm{cm}^{2}\right)$. Deconvoluted data are shown in Fig 3 in the manuscript. 


\subsection{Photooxidation of HaloTag-DHTz in E. Coli}

LB broth $(10 \mathrm{~mL})$ containing $50 \mu \mathrm{g} / \mathrm{uL}$ Kanamycin was inoculated 1:500 with an overnight culture $(20 \mu \mathrm{L})$ of BL21 cells expressing the HaloTag protein in a $50 \mathrm{~mL}$ conical tube. The culture was grown to an OD of 0.6-0.8 at $37^{\circ} \mathrm{C}$ with vigorous shaking, at which point expression was induced with $250 \mu \mathrm{M}$ IPTG and the solution was incubated at $16{ }^{\circ} \mathrm{C}$ overnight. The cells were pelleted at 5000x $\mathrm{g}$ and washed once with chelated PBS, before being diluted to an OD of 0.8 and treated with $25 \mu \mathrm{M} 1 \mathrm{c}$ for 45 minutes at $18{ }^{\circ} \mathrm{C}$ in PBS. Excess ligand was removed by washing $3 \mathrm{x}$ in PBS. The cells were resuspended in PBS and stored on ice, protected from light. If storage for longer than 24 hours was required, cells were flash frozen in liquid $\mathrm{N}_{2}$ and stored at $-80^{\circ} \mathrm{C}$ for up to a week.

The DHTz labeled cells were treated with $0.4 \mu \mathrm{M}$ SiR$\mathbf{t J F}_{646}$ and $5 \mu \mathrm{M}$ s-TCOTAMRA $^{4}$ and incubated on

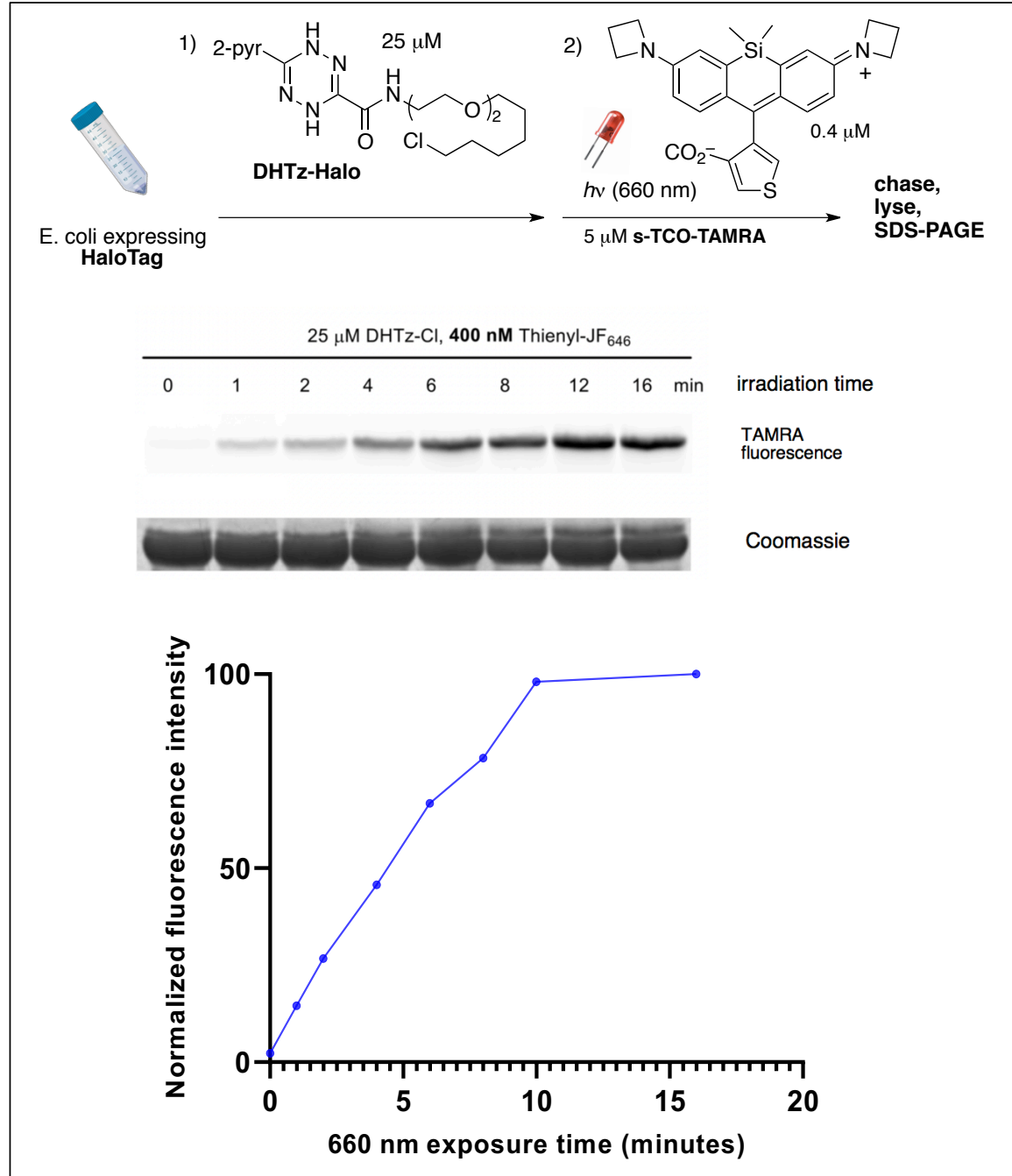

Figure S17. E. coli cells expressing H6-TEV-Halotag were labeled with 1c for 45 minutes, then treated with SiR-tJF $\mathbf{H 4 6}_{\mathbf{6}}$ and s-TCO-TAMRA. Cells were then irradiated with $660 \mathrm{~nm}$ light for varying amounts of time. After unreacted s-TCO-TAMRA was quenched, the cells were lysed and the extent of HaloTag-DHTz oxidation was determined via SDS-PAGE fluorescence, with more intense bands corresponding to a higher degree of photooxidation. ice for 30 minutes, then irradiated with $660 \mathrm{~nm}$ light. After irradiation, any unreacted s-TCOTAMRA was quenched with the addition of $125 \mathrm{mM}$ (4-(6-methyl-1,2,4,5-tetrazin-3yl)phenyl)methanamine, and the cells were pelleted at 5000x $\mathrm{g}$ for 10 minutes. The supernatant was aspirated, and the pellets were resuspended in $20 \mu \mathrm{L} 2 \mathrm{x}$ SDS loading dye before being boiled at $95{ }^{\circ} \mathrm{C}$ for 10 minutes. The sample was pelleted at 20,000x g for 10 minutes, and $6 \mu \mathrm{L}$ of the supernatant was loaded onto a 4-12\% SDS-PAGE gel and run at $100 \mathrm{~V}$ until the dye front ran off the gel. The TAMRA fluorescence was read on the FluoroChem Q imaging system, and the 
gel was stained using Coomassie brilliant blue for one hour before destaining in a 5:4:1 mixture of water, methanol, and acetic acid for 4 hours.

6.1: HeLa Cell Culture and Transfection: HeLa cells were grown in Dulbecco's modified eagle medium (DMEM, Life Technologies) supplemented with 10\% (v:v) heat inactivated fetal bovine serum (Life Technologies), $2 \mathrm{mM}$ 1-glutamine, and 100 units/mL penicillin/streptomycin (Life Technologies) in a humidified incubator at $37^{\circ} \mathrm{C} / 5 \% \mathrm{CO}_{2}$.

Transfection was performed with cells at 80-90\% confluency using Lipofectamine 3000 according to the manufacturer's instructions. HeLa cells were incubated for 5 hours at $37{ }^{\circ} \mathrm{C} / 5 \%$ $\mathrm{CO}_{2}$ before being exchanged with antibiotic free growth media for 16-20 hours prior to experimental procedures. All media used was lacking in phenol-red to eliminate any potential photosensitizing effects.

\section{2: HeLa Cell HaloTag Labeling for in-gel fluorescence}

HeLa cells transfected with HaloTag-POI-GFP were grown in $35 \mathrm{~cm}^{2}$ poly-L-lysine coated dishes and washed with chelated DPBS before being placed into OptiMem reduced serum media. Cells were then treated with either $10 \mu \mathrm{M} 1 \mathrm{c}$ or $10 \mu \mathrm{M}$ TAMRA-Halo for 30 minutes at 37 ${ }^{\circ} \mathrm{C} / 5 \% \mathrm{CO}_{2}$. After incubation, cells were washed 3x with metal-free DPBS and incubated for an additional hour in phenol-red free DMEM to remove excess ligand. After an additional media swap, the cells were prepared for photooxidation.

For oxidation with SiR-tJF 646 , cells were incubated with $2.5 \mu \mathrm{M}$ of the dye and $2.5 \mu \mathrm{M}$ o-TCOTAMRA for 30 minutes, after which point they were exposed to $2 \mathrm{~mm}$ ascorbic acid and immediately transferred to a custom $660 \mathrm{~nm}$ irradiation setup (Fig. S18).

For oxidation with FDA, the cells were incubated for 30 minutes with $10 \mu \mathrm{M}$ of the dye in DPBS, then washed once more with DPBS to remove any extracellular fluorescein and replaced with new media. o-TCO-TAMRA was then added and allowed to enter the cells for 10 minutes before exposing to $470 \mathrm{~nm}$ light $\left(60 \mathrm{~mW} / \mathrm{cm}^{2}\right)$ for FDA. Care was taken to wait no longer than 30 minutes before carrying out the irradiation, since the nascent FL has a tendency to leak out of cells after hydrolysis.

With all experiments, wells treated with $10 \mu \mathrm{M}$ TAMRA-Halo served as positive controls for conjugation of fluorophore to the protein, and the resulting gels were normalized accordingly. In addition, each time-course experiment had a well that was exposed to photocatalyst but was not irradiated. This well acted as a negative control.

After light exposure, the cells were incubated for an additional 30 minutes before being washed 3x in PBS supplemented with $125 \mu \mathrm{M}$ (4-(6-methyl-1,2,4,5-tetrazin-3-yl)phenyl)methanamine to quench unreacted TCO. Cells were then scraped in cold PBS and pelleted at 2000x g for 3 minutes. The supernatant was aspirated, and the pellets were flash-frozen in liquid $\mathrm{N}_{2}$ and stored at $-80{ }^{\circ} \mathrm{C}$ until further use. 


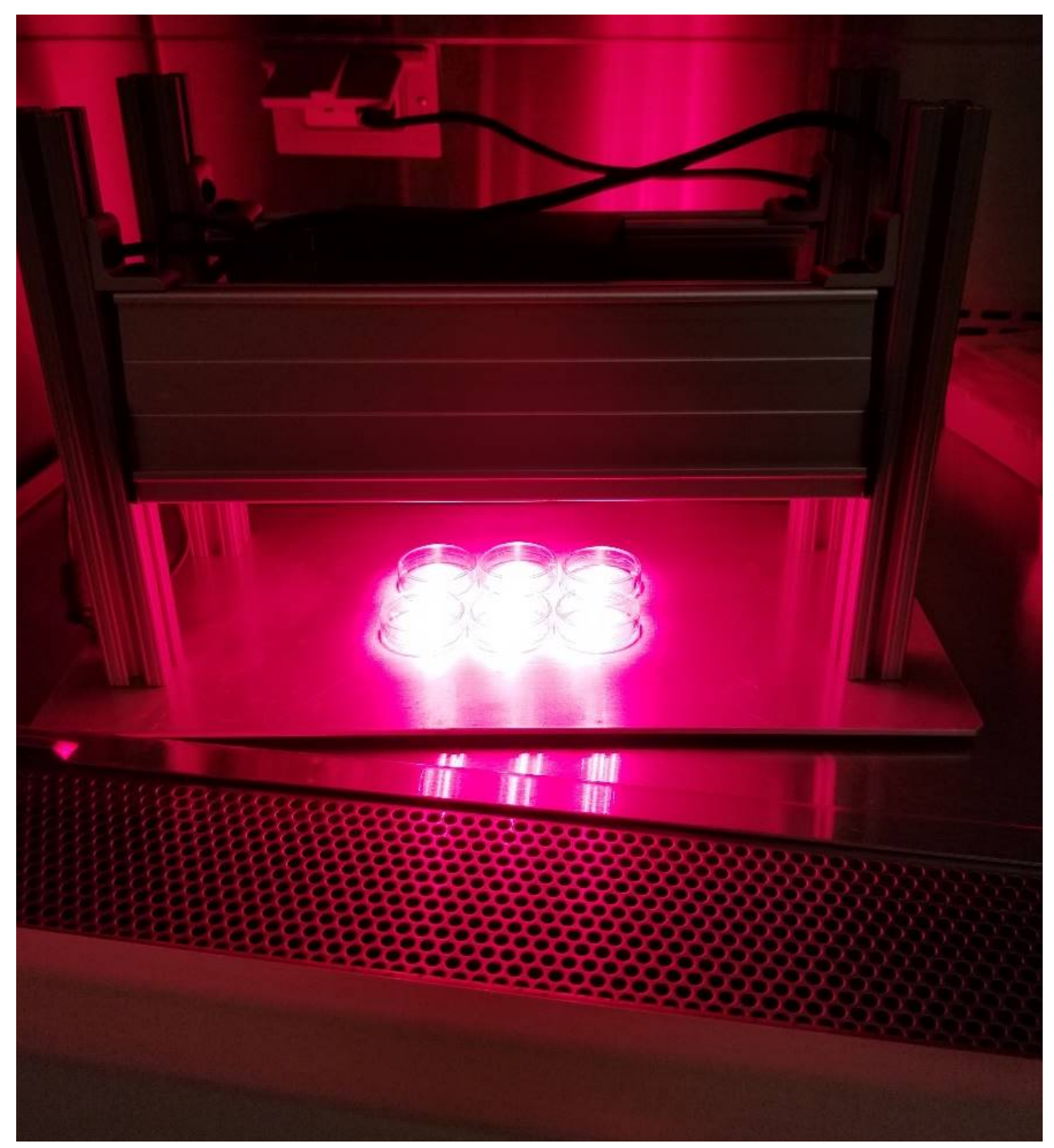

Figure S18: Custom built $660 \mathrm{~nm}$ irradiation apparatus allows for simultaneous irradiation of $6 \times 35 \mathrm{~cm}^{2}$ petri dishes or one standard 6-well plate.

6.3: HeLa Cell Lysis, SDS-PAGE, In-Gel Fluorescence and Western Blotting (Fig. 4, Fig. S19-20)

Cell pellets were resuspended in RIPA lysis buffer supplemented with protease inhibitors and lysed by freeze-thawing $3 x$ in liquid $\mathrm{N}_{2}$. The lysate was then centrifuged for 30 minutes at $10000 x \mathrm{~g}$. Protein concentration in the lysates was determined via bicinchoninic acid (BCA) assay. $20 \mu \mathrm{g}$ of protein was mixed with $4 \mathrm{x}$ SDS loading dye and run on a 4-15\% MiniPROTEAN® TGX ${ }^{\mathrm{TM}}$ Precast Protein Gel.

Proteins were blotted onto a nitrocellulose membrane at $25 \mathrm{~V}$ overnight at $4{ }^{\circ} \mathrm{C}$ and blocked with odyssey blocking buffer for 1 hour at room temperature. The membrane was then incubated with 1:1000 mouse Anti-HaloTag mAb in TBST for 1 hour. After incubation, the membrane was 
washed for 20 minutes 3x in TBST, before being incubated with goat Anti-mouse HRP antibody for 30 minutes. The membrane was then washed 3x in TBST for 20 minutes before incubated with WestPico ECL substrate according to the manufacturer's instructions. The membrane was then imaged on the FluoroChem Q system for TAMRA signal on the CY3 channel and total HaloTag signal on the chemiluminescence channel.

The extent of conjugation of o-TCO-TAMRA to the HaloTag protein was determined by CY3 fluorescence intensity, which was then normalized to total HaloTag protein content through the chemiluminescence signal. Individual lanes were analyzed using ImageJ software. In each experiment, lanes representing cells exposed to TAMRA-Halo served as a positive control representing conjugation of fluorophore to the protein. Since the extent of TAMRA conjugation to the HaloTag is dependent on such factors as ligand permeability, subcellular dye accumulation, and substrate specificity, the TAMRA-Halo controls are only a semi-quantitative measure of the efficiency of two-step conjugation using DHTz-Halo and o-TCO-TAMRA. 
A

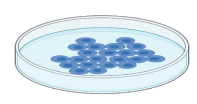

Hela cells expressing HaloTag-POI-GFP
1)<smiles>CC[Te][Te]</smiles><smiles>O=C(I)C1=NNC([Al])=NN1</smiles>

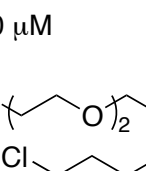
DHTz-Halo
2)<smiles>CC(=O)Oc1ccc2c(c1)Oc1cc(OC(C)=O)ccc1C21OC(=O)c2ccccc21</smiles>
then wash chase, lyse, SDS-PAGE

\section{A. HaloTag-GAP43-GFP (cytosol)}

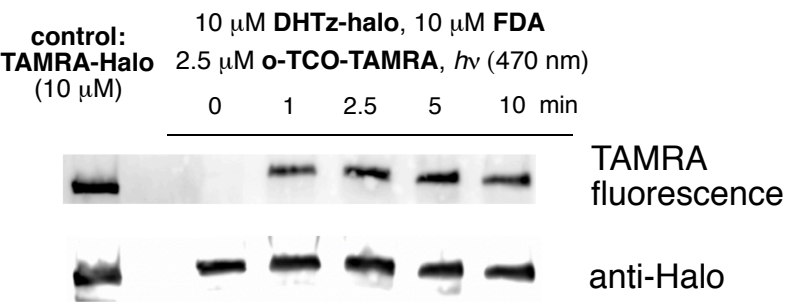

B. HaloTag-mito-GFP (mitochondria)

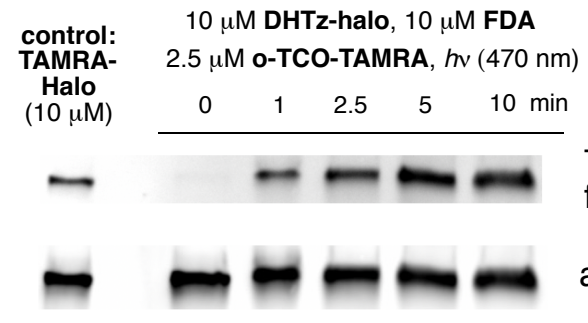

TAMRA fluorescence anti-Halo

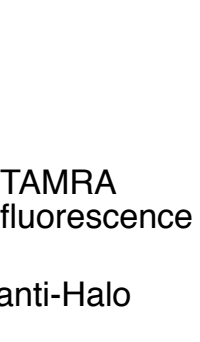

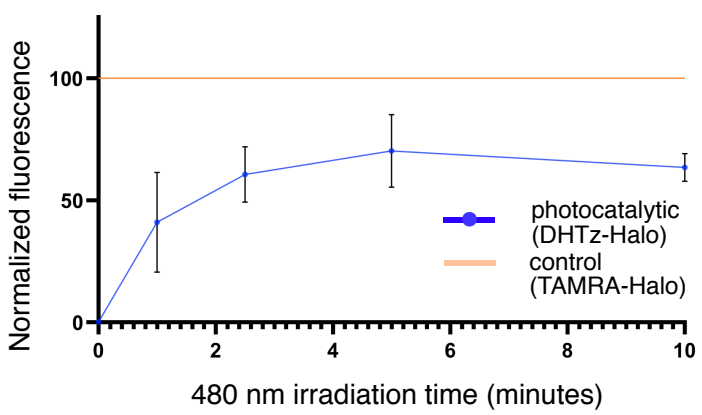

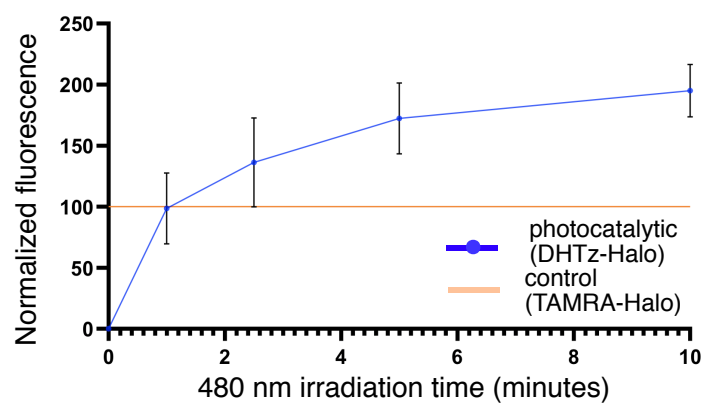

\section{HaloTag-H2B-GFP (nucleus)}
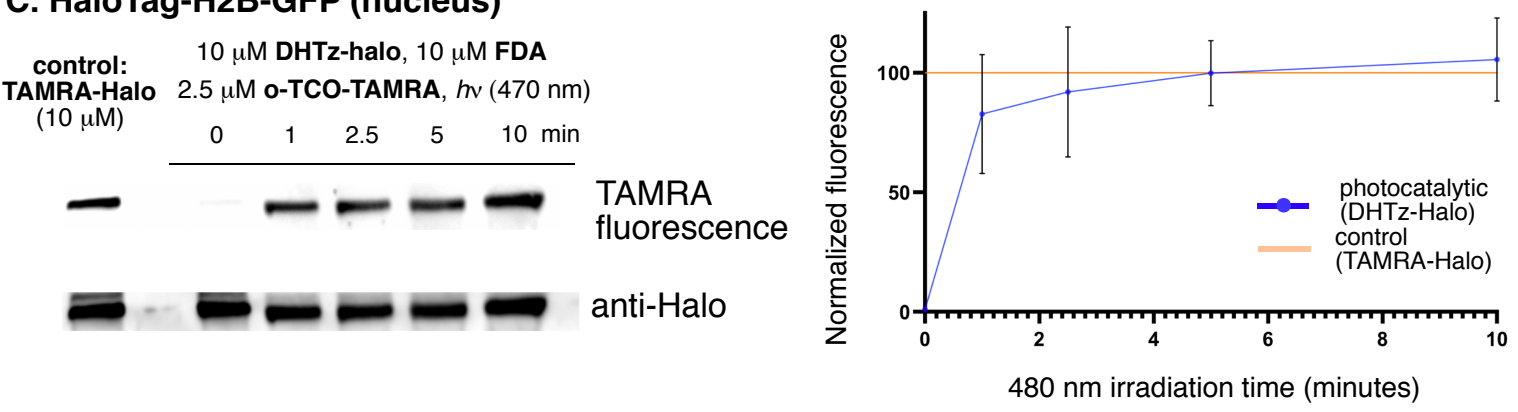

Figure S19: In-gel fluorescence results for DHTz oxidation in HeLa cells using $470 \mathrm{~nm}$ light and FDA (SI section 6.2). Cells containing HaloTag-POI-GFP (POI = protein of interest) were exposed to 1c and exposed to light for varying amounts of time. TAMRA-Halo was used as a positive control representative of conjugation of fluorophore to HaloTag (orange line). 
A

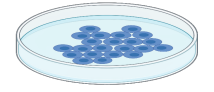

Hela cells

expressing HaloTag-POI-GFP
1)<smiles>NC(=O)C1=NNC(C(=O)OCc2ccccc2)=NN1</smiles>

DHTz-Halo<smiles>CC1CCCCCCCCOCC1</smiles>

then wash

2)<smiles>C[Si]1(C)C2=C[C+](N3CCC3)C=CC2=C(c2cscc2OC(=O)OCc2ccccc2)c2ccc(N3CCC3)cc21</smiles>

chase, lyse, SDS-PAGE

\section{A. Halo-GAP43-GFP (cytosol)}
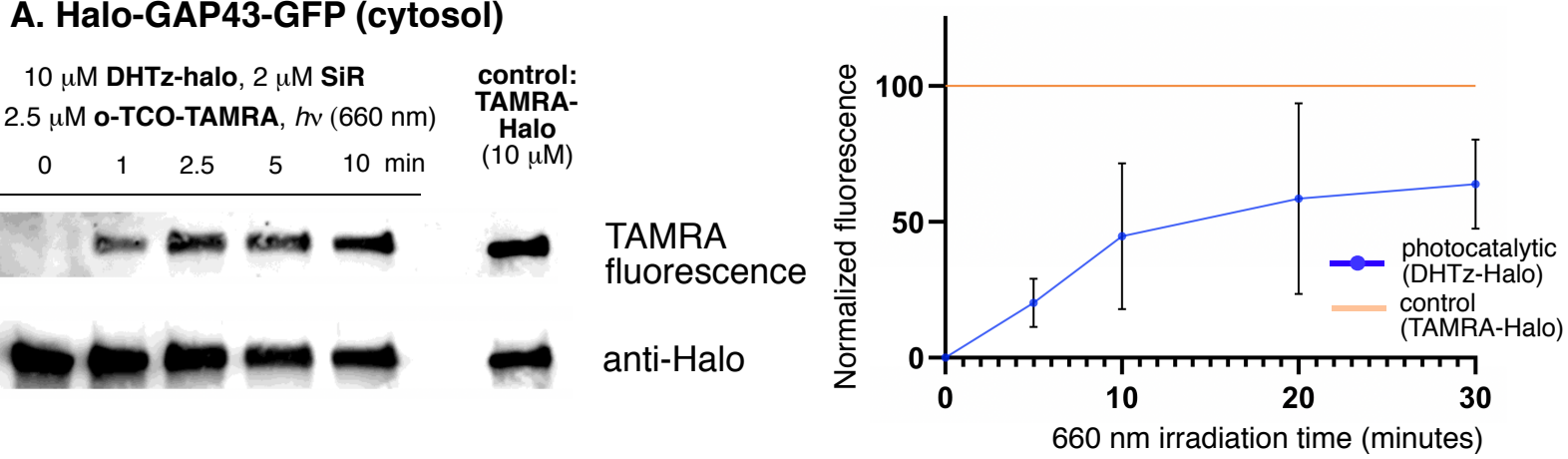

\section{B. Halo-mito-GFP (mitochondria)}
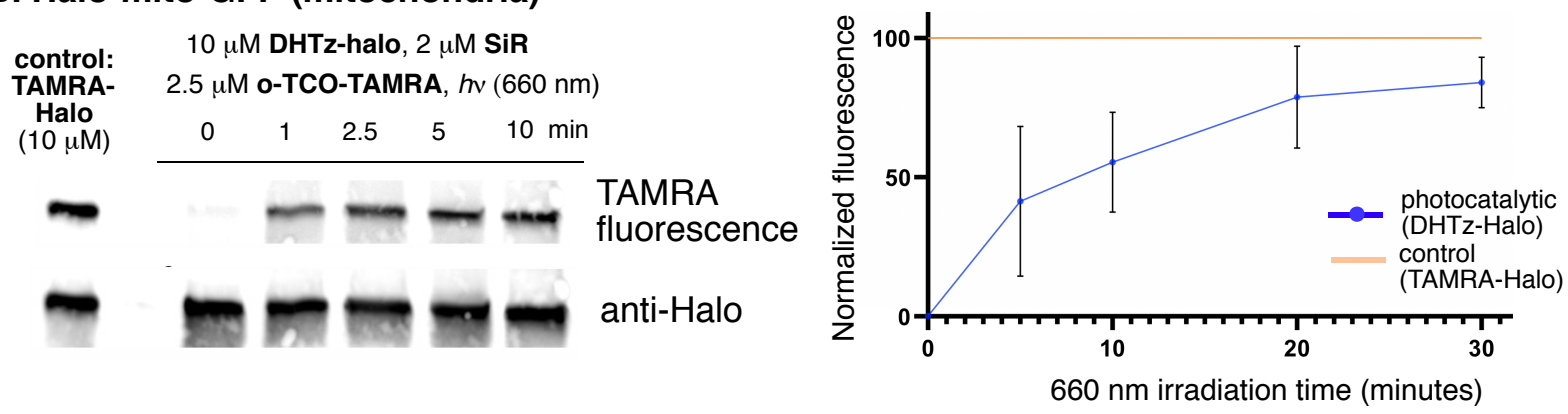

\section{Halo-H2B-GFP (nucleus)}
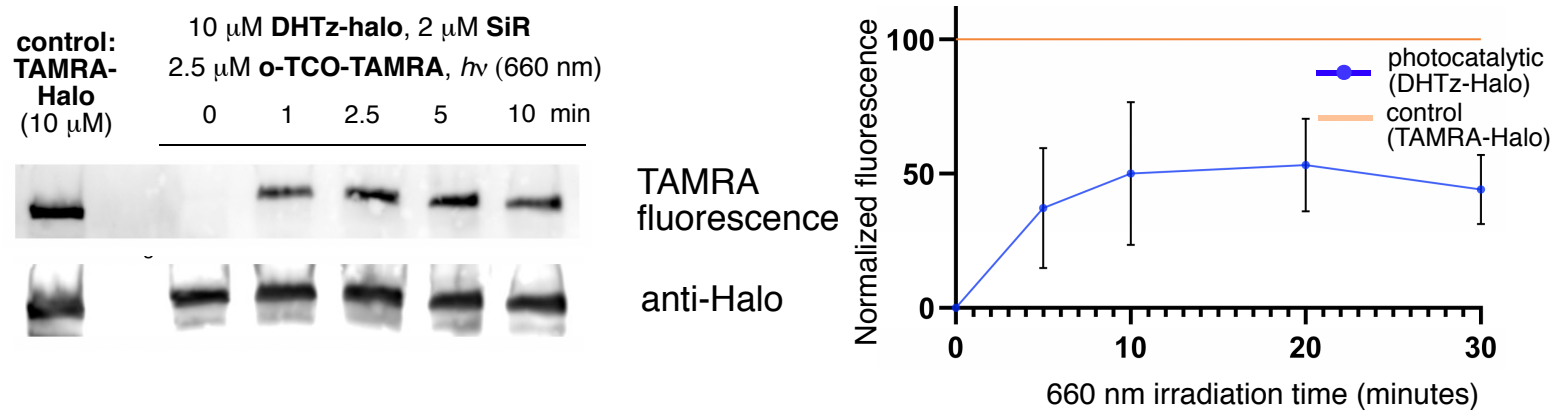

Figure S20: In-gel fluorescence results for DHTz oxidation in HeLa cells using $660 \mathrm{~nm}$ light and SiR-tJF 646 (Section 6.2). Cells containing HaloTag-POI-GFP (POI = protein of interest) were exposed to 1c and exposed to light for varying amounts of time. TAMRA-Halo was used as a positive control representative of conjugation of fluorophore to HaloTag (orange line). 


\section{4: Re-Oxidation of Reduced MeTz-Halo in HeLa Cells (Fig. 5):}

HeLa cells transfected with HaloTag-H2B-GFP were grown in $35 \mathrm{~cm}^{2}$ poly-L-lysine coated dishes and washed with chelated DPBS before being placed into OptiMem reduced serum media. Cells were then treated with either $10 \mu \mathrm{M}$ MeTz-Halo or TAMRA-Halo for 30 minutes at 37 ${ }^{\circ} \mathrm{C} / 5 \% \mathrm{CO}_{2}$. After incubation, cells were washed 3x with metal-free DPBS and incubated for an additional hour in phenol-red-free DMEM to remove excess ligand. After an additional media swap, the MeTz-Halo labeled cells were incubated with $2.5 \mu \mathrm{M} \mathrm{SiR-tJF} \mathbf{6 4 6}^{1}$ and $2 \mu \mathrm{M}$ a-TCOTAMRA for 30 minutes, then exposed to $2 \mathrm{mM}$ ascorbic acid and irradiated for 20 minutes with $660 \mathrm{~nm}$ light to reoxidize dihydrotetrazine groups that were formed via intracellular reduction. As in SI 6.2, TAMRA-Halo served as a positive control representing complete fluorophore conjugation. Afterwards cells were washed, quenched, and pelleted, then analyzed via SDSPAGE.

\section{5: HeLa Fixed Cell Imaging (Fig. 6, Fig. S21)}

HeLa cells transfected with HaloTag-POI-GFP were grown on poly-L-lysine coated glass coverslips in a 24 well plate were washed with chelated DPBS before being placed into OptiMem reduced serum media. Cells were then treated with $10 \mu \mathrm{M} 1 \mathrm{c}$ for 30 minutes at 37 ${ }^{\circ} \mathrm{C} / 5 \% \mathrm{CO}_{2}$. After incubation, cells were washed $3 \mathrm{x}$ with chelated DPBS and incubated for an additional hour in phenol-red-free DMEM to remove excess ligand.

After an additional wash into fresh DMEM, cells were treated with $2.5 \mu \mathrm{M}$ SiR-tJF 646 and 2.5 $\mu \mathrm{M}$ o-TCO-TAMRA for 30 minutes, after which point were exposed to $2 \mathrm{~mm}$ ascorbic acid and irradiated with $660 \mathrm{~nm}$ light for 20 minutes. Once the irradiation was complete, o-TCO-TAMRA was quenched by washing 3x with DPBS supplemented with $125 \mu \mathrm{M}$ (4-(6-methyl-1,2,4,5-tetrazin3-yl)phenyl)methanamine, followed by a 3x with phenol red free DMEM. The cells were then allowed to sit in media for 2 hours to wash out any remaining dye, before washing once final time with media.

To fix cells, media was aspirated and the wells were washed $3 \mathrm{x}$ with PBS before fixation with $4 \%$ paraformaldehyde at room temperature for 10 minutes. Cells were washed $3 \mathrm{x}$ for 5 minutes in PBS before being mounted onto coverslips with VECTASHIELD ${ }^{\circledR}$ Antifade Mounting Medium with DAPI and stored at $4{ }^{\circ} \mathrm{C}$.

Cells were imaged on the Zeiss LSM 880 laser scanning confocal microscope using a PlanApochromat 63x/1.40 Oil immersion lens using AiryScan. In order to determine the TCO concentration necessary to capture the nascent tetrazines formed via DHTz oxidation, a wider field view was taken of cells labeled with $0.1,0.5$, or $1.0 \mu \mathrm{M}$ o-TCO-TAMRA. A representative sample of nuclei were analyzed for the ratio of TAMRA/GFP signal using ImageJ software, demonstrating signal saturation at approximately $0.5 \mu \mathrm{M}$ o-TCO-TAMRA (Fig. S20) 


\section{A}

DAPI
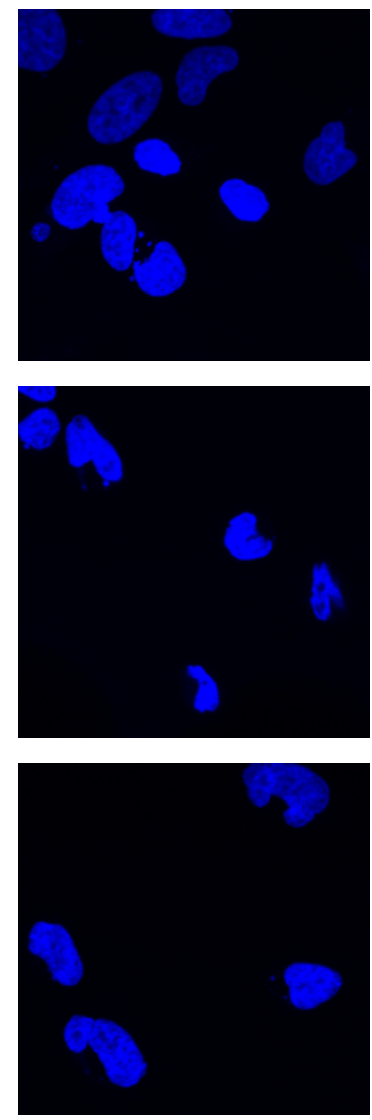

B
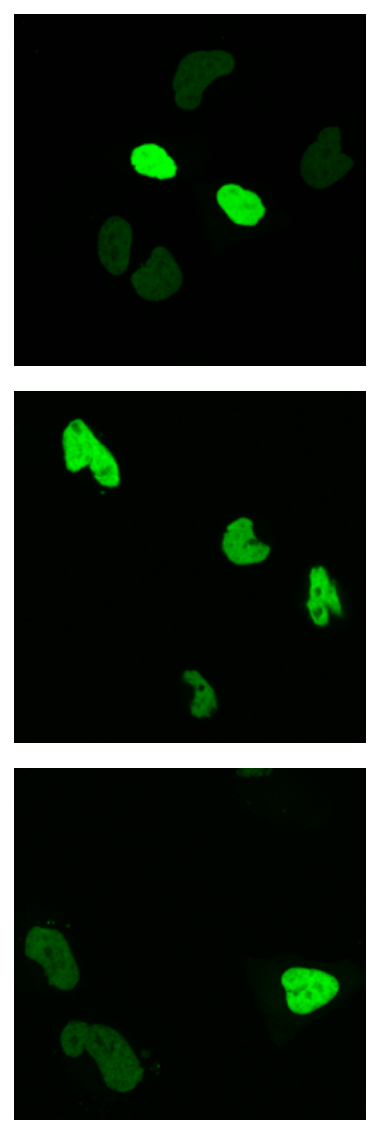

$0.5 \mu \mathrm{M}$

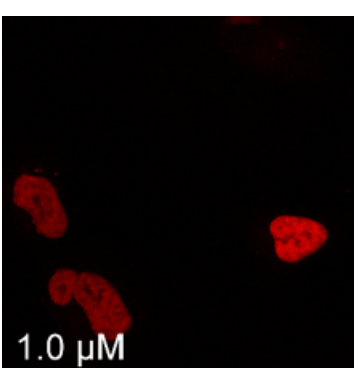

merge
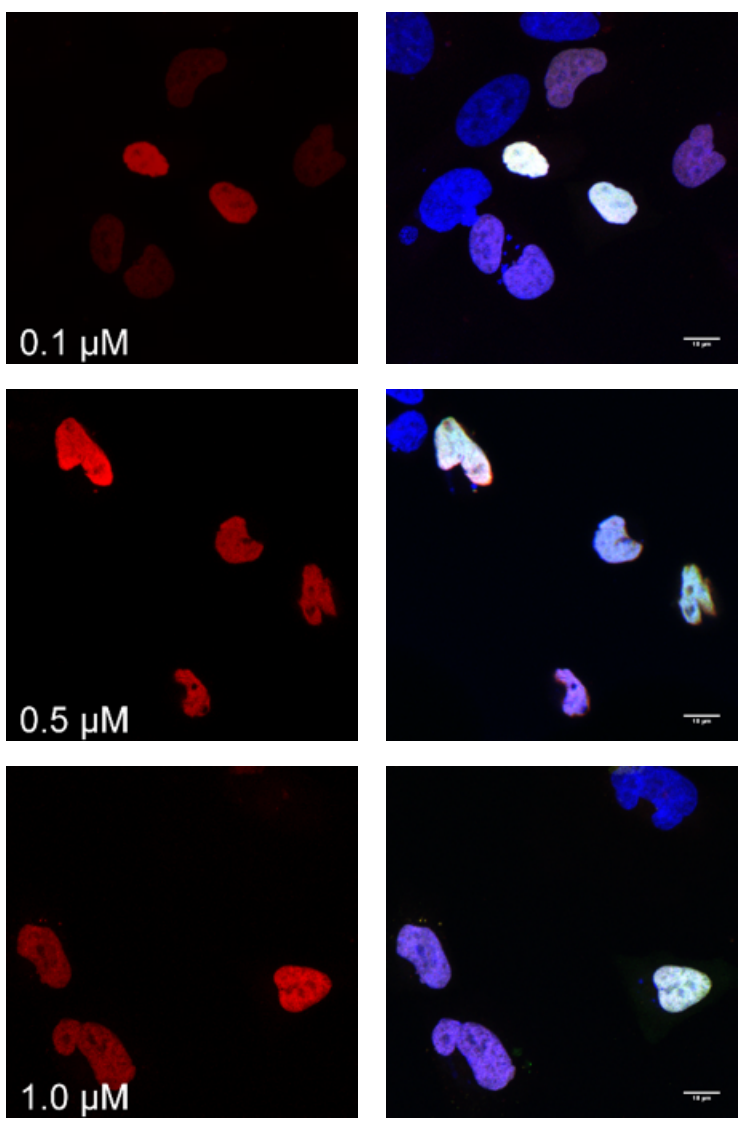

HaloTag-H2B-GFP

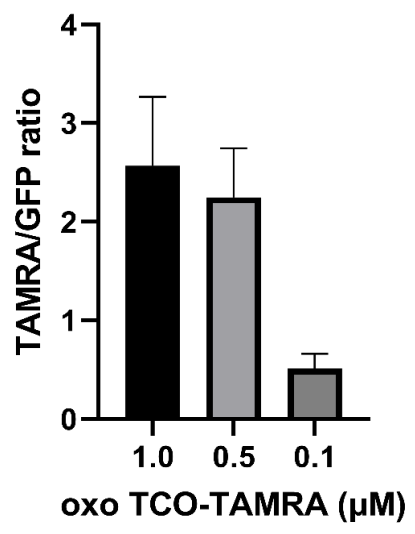

Fig S21: A: Confocal images of HaloTag-H2B-GFP ${ }^{3}$ labelled with 1c and photocatalytically oxidized with $2.5 \mu \mathrm{M}$ SiR-tJF 646 and 20 minutes of $660 \mathrm{~nm}$ light. Cells were exposed to varying amounts of o-TCO-TAMRA. (Scale bar $=10 \mu \mathrm{m}$ ) B: Ratio of TAMRA to GFP fluorescence from nuclei in $\mathbf{A}$, showing saturation at approximately $0.5 \mu \mathrm{M}$ o-TCO-TAMRA. 


\section{6: Live Cell Imaging (Fig. 7):}

HeLa cells were grown on fibronectin coated glass bottomed $35 \mathrm{~mm}$ dishes | No. 1.5 Coverslip (MatTek) and transfected with HaloTag-H2B-mCherry. The cells were then treated with $10 \mu \mathrm{M}$ 1c for 30 minutes at $37{ }^{\circ} \mathrm{C} / 5 \% \mathrm{CO}_{2}$. After incubation, cells were washed $3 \mathrm{x}$ with metal-free DPBS and incubated for an additional hour in phenol-red free DMEM to remove excess ligand. Prior to imaging, cells were washed with DPBS and placed into $1 \mathrm{~mL}$ Opti-Mem and labeled with $10 \mu \mathrm{M}$ FDA for at least 10 minutes before analysis or kept in an incubator until needed.

Just before loading onto the microscope, the cells were washed $1 \mathrm{x}$ with DPBS, and the media was replaced with $1 \mathrm{~mL}$ Opti-Mem containing $100 \mathrm{~nm}$ a-TCO-SiR. Cells were imaged on the Zeiss LSM 880 laser scanning confocal microscope using a Plan-Apochromat $63 \mathrm{x} / 1.40$ oil immersion lens. The $561 \mathrm{~nm}$ laser was used to excite mCherry fluorescence and for differential interference contrast (DIC). The $633 \mathrm{~nm}$ laser was used to excite SiR fluorescence. Samples imaged using these parameters to find cells that strongly expressed mCherry-H2B-HaloTag. These cells were irradiated using the bleaching function of the Zen software suite, irradiating a region with a Coherent Chameleon Vision II Ti:Sapphire laser tuned to $880 \mathrm{~nm}$ and a differential scan speed set to 12 for a pixel dwell time of $0.45 \mu$ s. If fast labeling was desired, a laser power of $25-30 \%$ was used, at the expense of partial photobleaching of mCherry and extant SiR tagged proteins. In order to get on-off kinetics, the laser intensity was lowered to $10 \%$. Using the "regions" tool, individual cells and shapes were able to be labeled separately from the rest of the plate.

\section{7: Analysis of Photoactivation Kinetics and Spatial Resolution}

A square portion of a nucleus expressing HaloTag-H2B-mCherry according to the procedure in SI 6.6 was irradiated with a brief pulse of $880 \mathrm{~nm}$ laser light. The subsequent increase in fluorescence intensity on the $633 \mathrm{~nm}$ laser channel in the irradiated section was then measured and compared to an equal sized area directly underneath in the section that was not irradiated (Fig. S21). The data show that the cycloaddition was complete after approximately 30 seconds.

In order to determine the spatial resolution of photoactivation, a line profile plot containing the illuminated section over the duration of the photoactivation was generated (Fig. S22). 

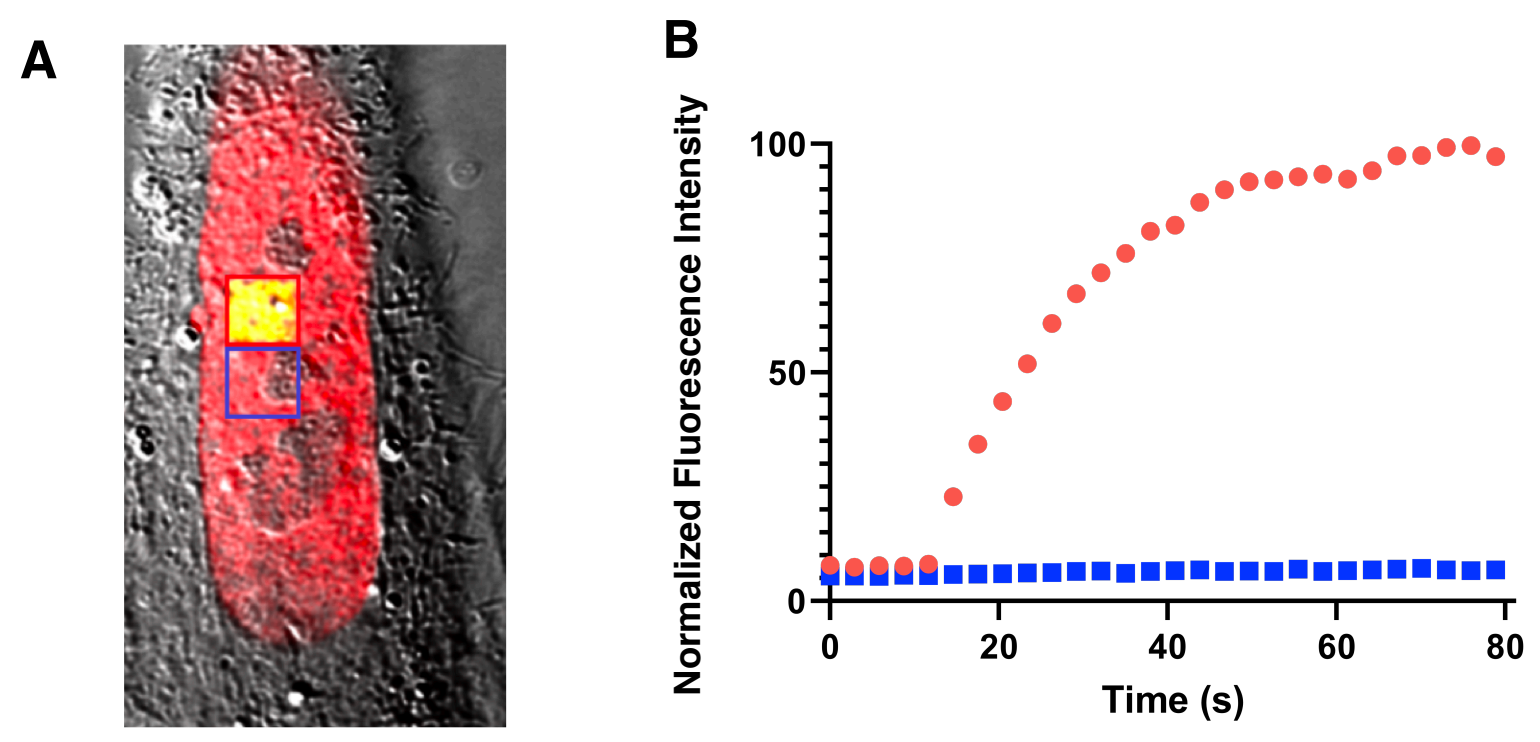

Fig. S22: A: A nucleus expressing HaloTag-H2B-mCherry and labeled with 1c was irradiated with a brief pulse of $880 \mathrm{~nm}$ light in the presence of $100 \mathrm{~nm}$ a-TCO-SiR and $10 \mu \mathrm{M}$ FDA (red square). B: Quantification of intensity on the SiR channel between the patch of the nucleus exposed to $880 \mathrm{~nm}$ light (red) and the area directly beneath it (blue).
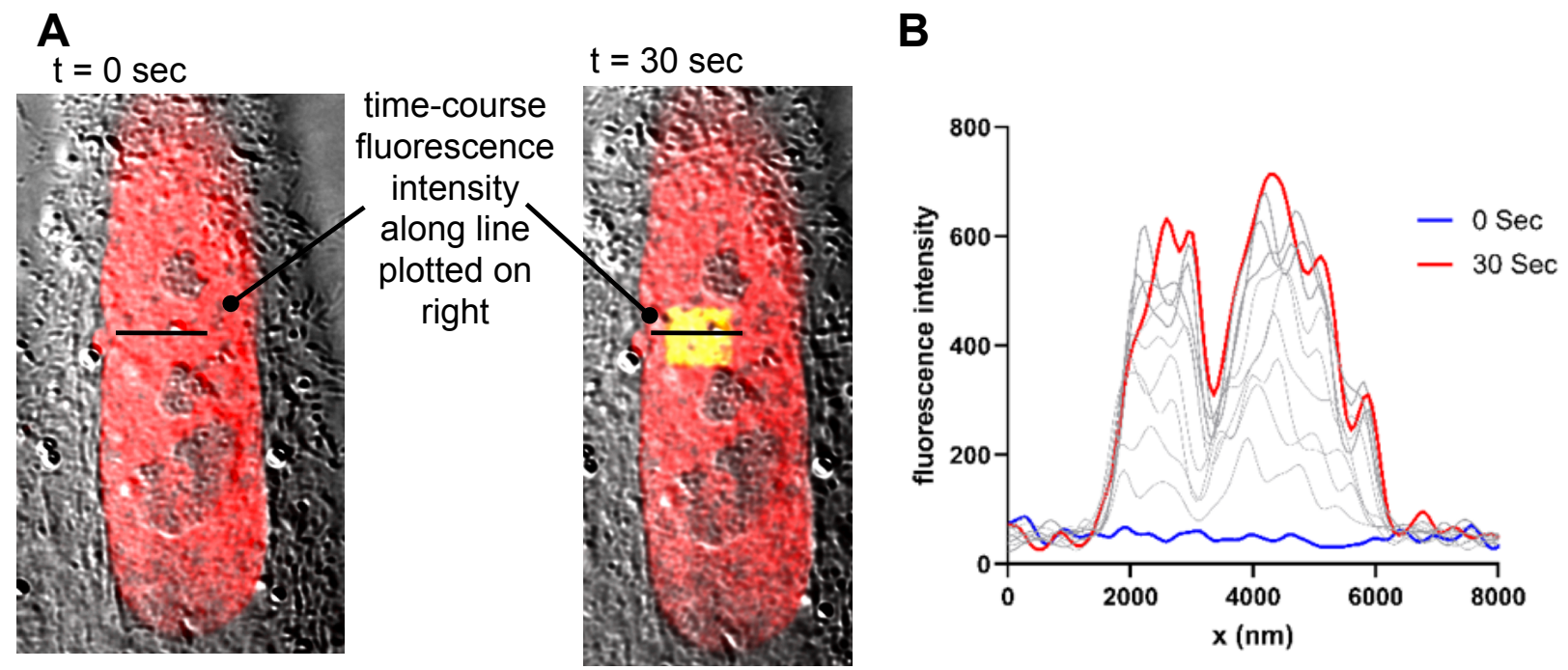

Fig. S23: Line profile plot spanning both an illuminated and non-illuminated region of the nucleus, showing that the activation was both spatially and temporally confined. (A) Images where lines mark the regions where fluorescence intensity was measured at $t=0$ and $t=30$. (B) Line-profile plot showing time-course monitoring of fluorescence along that line. 


\section{8: Extracellular DHTz Activation}

HeLa cells were grown on fibronectin coated glass bottomed $35 \mathrm{~mm}$ dishes $\mid$ No. 1.5 Coverslip (MatTek) and transfected with HaloTag-mCherry-PDGFR to express the protein on the surface of the cell. The cells were then treated with $10 \mu \mathrm{M} 1 \mathrm{c}$ for 30 minutes at $37{ }^{\circ} \mathrm{C} / 5 \% \mathrm{CO}_{2}$ in phenolred free DMEM containing 10\% FBS. After incubation, cells were washed $3 \mathrm{x}$ with metal-free DPBS and incubated for an additional hour in phenol-red free DMEM to remove excess ligand. Prior to imaging, cells were incubated with $2 \mu \mathrm{M}$ fluorescein and $100 \mathrm{~nm}$ aTCO-SiR. Cells were imaged on the Zeiss LSM 880 laser scanning confocal microscope using a Plan-Apochromat $63 \mathrm{x} / 1.40$ oil immersion lens. The $633 \mathrm{~nm}$ laser was used both for differential interference contrast (DIC) and to excite SiR fluorescence. These cells were then irradiated using the bleaching function of the Zen software suite on the $488 \mathrm{~nm}$ laser line at $2 \%$ power (Fig. S23A). Approximately $10 \%$ background oxidation of $1 \mathrm{c}$ was observed.

A

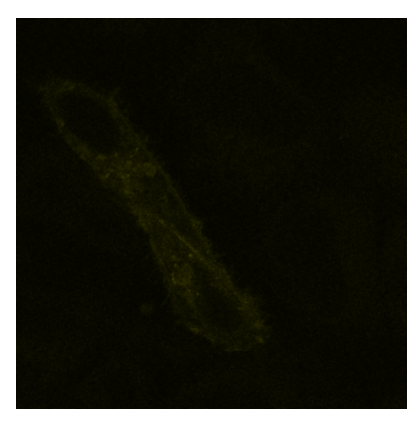

B

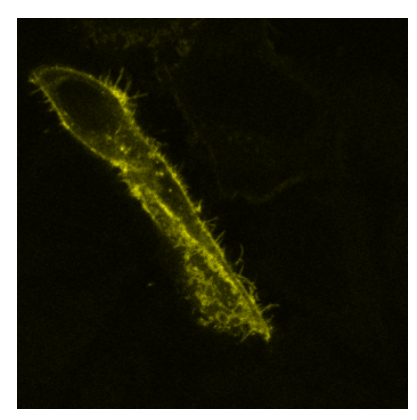

mCherry

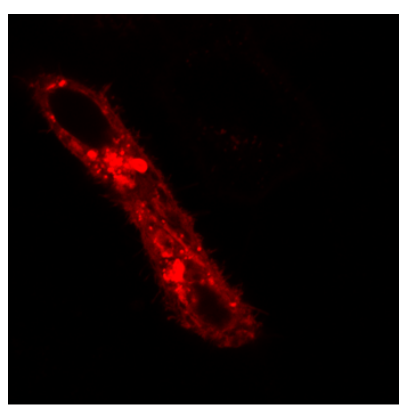

mCherry

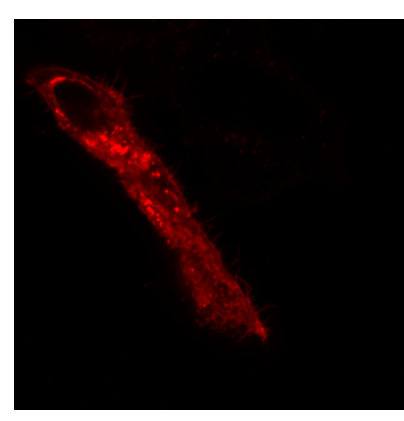

DIC

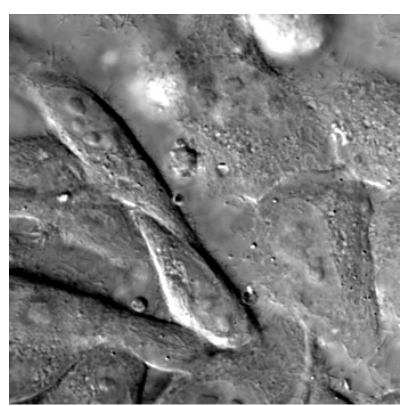

DIC

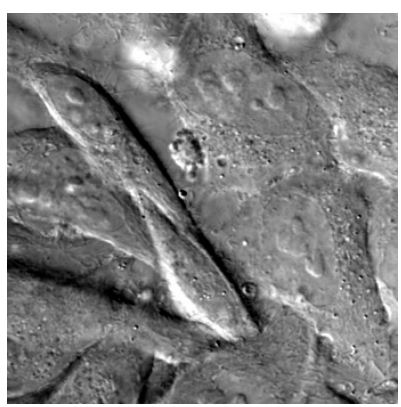

Merge

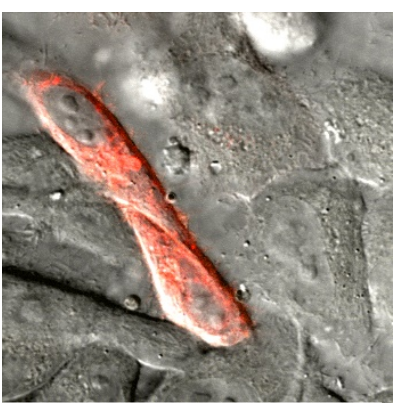

Merge

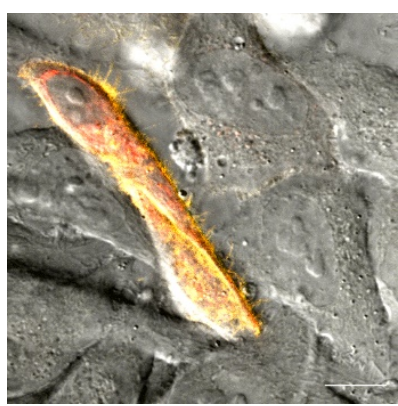

Figure S23A HeLa cells transfected with HaloTag-mCherry-PDGFR and labeled with 1c in the presence of $100 \mathrm{~nm}$ aTCO-SiR and $2 \mu \mathrm{M}$ fluorescein before (A) and after (B) 30 seconds of irradiation at $488 \mathrm{~nm}$. Scale bar $=10 \mu \mathrm{m}$ 


\subsection{MAGL in vitro activity assay.}

The MAGL in vitro activity assay was performed based on a reported protocol (Butler et al, $J$. Med. Chem. 2017, 60, 9860-9873). Briefly, human MAGL enzyme was pre-treated with MAGL-DHTz probe 14 at room temperature for $30 \mathrm{~min}$, and subsequently incubated with 7hydroxycoumarinyl arachidonate (7-HCA) as a substrate at room temperature for $1 \mathrm{~h}$. The fluorescence signals were measured on an Envision plate reader (excitation $355 \mathrm{~nm}$, emission $460 \mathrm{~nm}$ ). The $\mathrm{IC}_{50}$ was determined to be $13 \mathrm{nM}$.

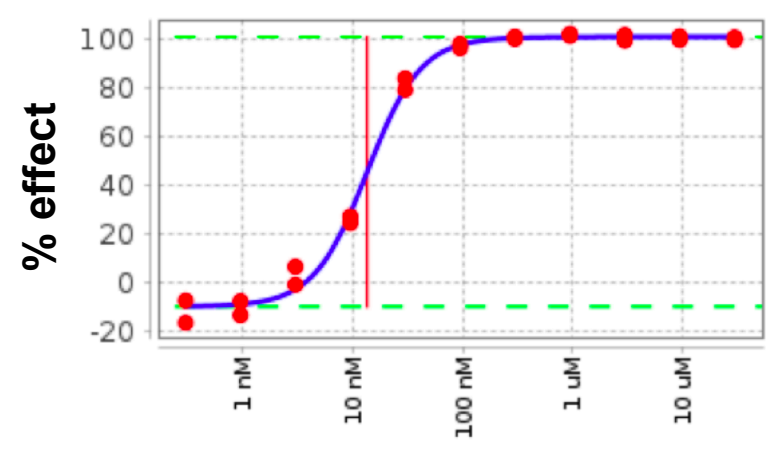

[14]

Fig. S24. Dose-response curve for MAGL-DHTz probe 14 in biochemical assay for MAGL in vitro activity.

\section{2: PC3 Cell Culture and MAGL-DHTz Probe Treatment}

PC3 cells (ATCC) were maintained in RPMI growth medium without phenol red, supplemented with $10 \%$ heat-inactivated fetal bovine serum (HI FBS) and $1 \%$ penicillin-streptomycin at $37{ }^{\circ} \mathrm{C}$ with $5 \% \mathrm{CO}_{2}$. Cells were plated onto poly-L-lysine coated 6-well plates in RPMI without penicillin-streptomycin and grown until $90 \%$ confluency was achieved. The cells were then washed $1 \mathrm{x}$ in metal-free DPBS and placed into Opti-Mem media. To determine specificity for the MAGL protein, cells were pretreated with $300 \mathrm{~nm}$ of the covalent MAGL inhibitor KML29 for one hour prior to experimental procedures.

The cells were then treated with MAGL-DHTz probe 14 (concentrations varied from 0.32 to $1000 \mathrm{~nm}$ ) at $37^{\circ} \mathrm{C}$ for one hour. The cells pre-treated with $300 \mathrm{~nm} \mathrm{KML} 29$ were treated with 10 $\mathrm{nm}$ 14. After probe incubation, the Opti-Mem was aspirated and replaced with metal-free DPBS containing $10 \mu \mathrm{M}$ FDA for 30 minutes at $37^{\circ} \mathrm{C}$. Afterwards the cells were washed $2 \mathrm{x}$ with DPBS, and subsequently treated with Opti-Mem containing $100 \mathrm{~nm}$ a-TCO-SiR. The plate was then irradiated for 1 minute with $470 \mathrm{~nm}$ light $\left(60 \mathrm{~mW} / \mathrm{cm}^{2}\right)$, after which the reaction was quenched with $125 \mu \mathrm{M}$ (4-(6-methyl-1,2,4,5-tetrazin-3-yl)phenyl)methanamine in cold PBS. The cells were harvested using a cell scraper and pelleted at 4,000 xg for 3 minutes, then flash frozen in liquid nitrogen and optionally stored at $-80{ }^{\circ} \mathrm{C}$ until further use. 


\section{3: PC3 Cell Lysis, SDS-PAGE, and In-Gel Fluorescence (Fig. 8C-E)}

The cells were placed into RIPA lysis buffer supplemented with protease inhibitors and lysed by $3 \mathrm{x}$ freeze thawing. After lysis, cells were pelleted at 10,000 xg for 20 minutes and the supernatant was harvested. Protein concentration of the clarified lysate was determined via a BCA assay, and $20 \mu \mathrm{g}$ of total protein was loaded onto a 4-12\% bis-tris 10-well protein gel in $\mathrm{n}$ 2-( $N$-morpholino)ethanesulfonic acid (MES) buffer. Labelled proteins were visualized on the FluoroChem Q imaging system using the CY5 channel. In order to visual total protein content, the gel was stained overnight in Coomassie brilliant blue, followed by destaining in a 5:4:1 mixture of water, methanol, and acetic acid for 4 hours. The gel was once again visualized on the FluoroChem Q imaging system using the trans illumination setting. ImageJ was used to determine the in-gel fluorescence intensity of the MAGL bands, which was then normalized to the Coomassie stain. EC50 calculations were performed by fitting data to a nonlinear fit of dose vs. response using GraphPad Prism 9.1.2.

A

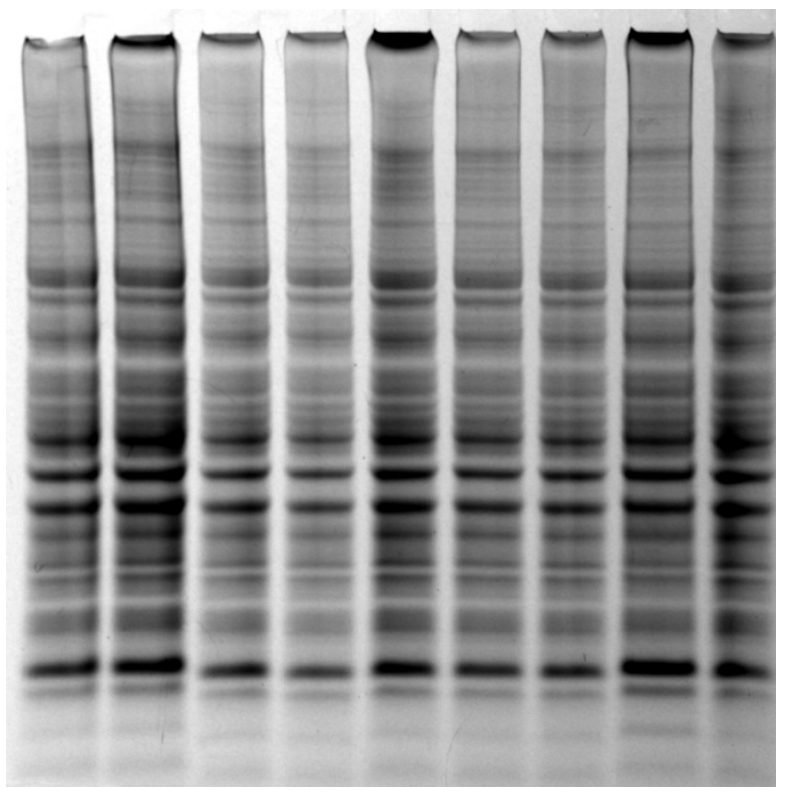

B

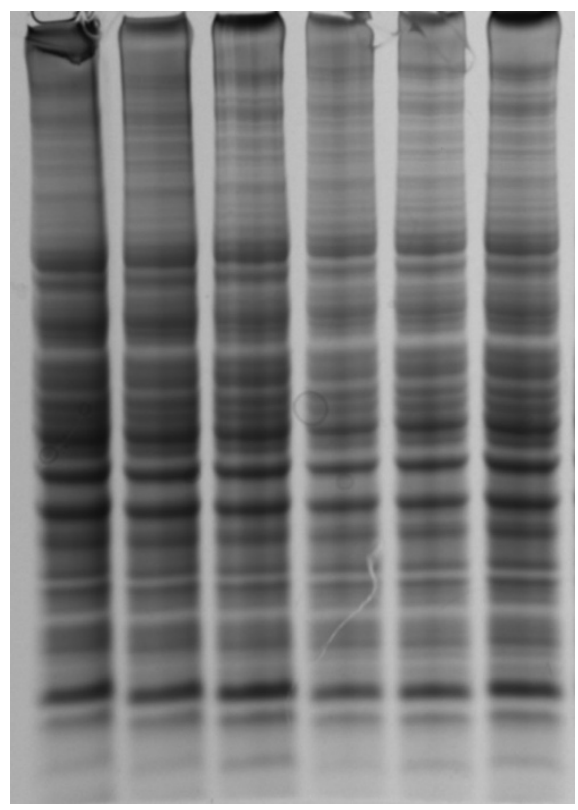

Fig. S25: Coomassie stains of gels shown in (A) Fig. 8C and (B) 8E.

\section{4: Confocal Imaging of MAGL-DHTz in PC3 Cells (Fig. F-I)}

PC3 cells were grown in fibronectin coated glass bottomed $35 \mathrm{~mm}$ dishes | No. 1.5 Coverslip (MatTek) in RPMI without penicillin-streptomycin until 90\% confluency was achieved. Cells were washed once in chelated DBPS, then incubated with $32 \mathrm{~nm}$ MAGL-DHTz probe 14 in Opti-Mem buffer for $1 \mathrm{~h}$. After probe incubation, cells were incubated in DPBS containing 10 
$\mu \mathrm{M}$ FDA for 30 minutes at $37^{\circ} \mathrm{C}$. Afterwards the cells were washed $2 \mathrm{x}$ with DPBS to remove extracellular fluorescein, and subsequently treated with Opti-Mem containing $50 \mathrm{~nm}$ a-TCOSiR.

Immediately prior to loading onto the microscope, the cells were washed $1 \mathrm{x}$ with DPBS, and the media was replaced with $1 \mathrm{~mL}$ Opti-Mem containing $50 \mathrm{~nm}$ a-TCO-SiR. Cells were imaged on the Zeiss LSM 880 laser scanning confocal microscope using a Plan-Apochromat $63 \mathrm{x} / 1.40$ oil immersion lens. The $633 \mathrm{~nm}$ laser was used both for differential interference contrast (DIC) and to excite SiR fluorescence. These cells were then irradiated using the bleaching function of the Zen software suite on the $488 \mathrm{~nm}$ laser line at $2 \%$ power.

\section{5: TIRF Imaging of MAGL-DHTz In PC3 Cells}

PC3 cells were grown in glass bottomed $35 \mathrm{~mm}$ dishes | No. 1.5 Coverslip (MatTek) that had been cleaned with a piranha solution and coated in poly-l-lysine. The cells were grown in RPMI without penicillin-streptomycin until 90\% confluency was achieved. Cells were washed once in chelated DBPS, then incubated with $32 \mathrm{~nm}$ MAGL-DHTz probe 14 in Opti-Mem buffer for $1 \mathrm{~h}$. After probe incubation, cells were incubated in DPBS containing $10 \mu \mathrm{M}$ FDA for 30 minutes at $37^{\circ} \mathrm{C}$. Afterwards the cells were washed $2 \mathrm{x}$ with DPBS to remove extracellular fluorescein, and subsequently treated with Opti-Mem containing $100 \mathrm{~nm}$ a-TCO-SiR.

Cells were then promptly imaged on an Andor Dragonfly 505 that can switch between spinning disk confocal microscopy (SDCM) and total internal reflection fluorescence microscopy (TIRFM). Cells were first photon labeled and imaged in TIRFM mode using a Plan Apochromat 63x/1.47 objective lens and a Zyla 4.2 Plus sCMOS camera. The TIRF angle was set for approximately $100 \mathrm{~nm}$ of illumination depth of the $488 \mathrm{~nm}$ laser into the cells. Three 20 second repetitions of $488 \mathrm{~nm}$ illumination at $10 \%$ laser power were used to photo label the cells and the $637 \mathrm{~nm}$ laser was used to monitor SiR fluorescence. Following TIRF photo-labeling, a 2 x $2 \mathrm{z}-$ stack tile of the region was acquired by SDCM.

\section{1: MTT Assays}

HeLa cells were seeded onto fibronectin coated 96 well plates in phenol-red free DMEM supplemented with 10\% FBS and incubated for 24 hours. To evaluate SiR phototoxicity, cells were exposed to $3.2 \mu \mathrm{M}$ thienyl $\mathrm{SiR}$ in the presence or absence of ascorbic acid $(2 \mathrm{mM})$, then irradiated for 10 minutes at $660 \mathrm{~nm}\left(450 \mathrm{~mW} / \mathrm{cm}^{2}\right)$. As additional controls, cells with or without ascorbic acid ( $2 \mathrm{mM}$ ) were irradiated for 10 minutes at $660 \mathrm{~nm}$. After 10 more minutes, wells were washed $3 \mathrm{x}$ with media to wash out $\mathrm{SiR}$ and ascorbic acid, and the cells were incubated for an additional 24 hours at $37^{\circ} \mathrm{C}$. In order to evaluate FDA phototoxicity, HeLa cells were again seeded onto a fibronectin coated 96 well plate in DMEM. Wells were washed 2x in DPBS, then labeled with $10 \mu \mathrm{M}$ FDA for 30 minutes before washing 2x with DMEM and irradiating for 2 minutes with $470 \mathrm{~nm}$ light $\left(60 \mathrm{~mW} / \mathrm{cm}^{2}\right)$. Cells were then incubated for 2 hours at $37^{\circ} \mathrm{C}$. 
After incubation, $10 \mu \mathrm{L}$ of sterile filtered MTT (3-(4,5-dimethylthiazol-2-yl)-2,5diphenyltetrazolium bromide) $(5 \mathrm{mg} / \mathrm{mL})$ dissolved in DMEM were added to each well, and cells were incubated for an additional 3 hours at $37^{\circ} \mathrm{C}$. After incubation, the media was aspirated, and precipitated formazan crystals were dissolved with the addition of $200 \mu \mathrm{L}$ DMSO. The absorbance at $570 \mathrm{~nm}$ was then read, and the data was normalized to an identical plate that had not been exposed to light and photocatalyst (Fig. S26).
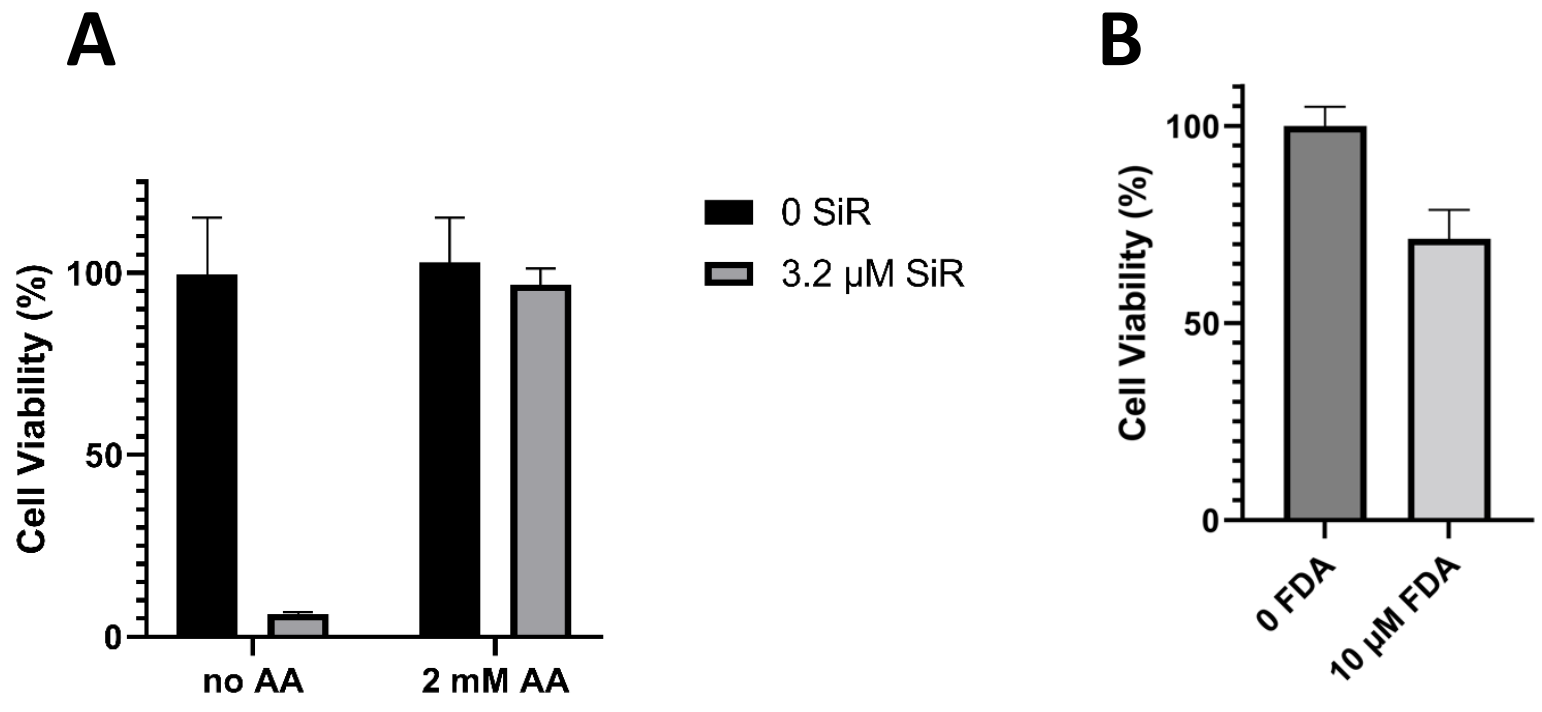

Fig. S26 (A) 24-hour MTT assay results for irradiating HeLa cells with 10 minutes of $660 \mathrm{~nm}$ $\left(450 \mathrm{~mW} / \mathrm{cm}^{2}\right)$ light in the presence or absence of $3.2 \mu \mathrm{M}$ thienyl-SiR, with or without $2 \mathrm{mM}$ ascorbic acid (AA). (B) 2-hour MTT assay results for irradiating HeLa cells with 2 minutes of $470 \mathrm{~nm}$ light $\left(60 \mathrm{~mW} / \mathrm{cm}^{2}\right)$ in the presence or absence of labeling with $10 \mu \mathrm{M}$ FDA.

\section{References}

(1) Grimm, J. B.; Brown, T. A.; Tkachuk, A. N.; Lavis, L. D. General Synthetic Method for SiFluoresceins and Si-Rhodamines. ACS Cent. Sci. 2017, 3, 975-985.

(2) Pigga, J. E.; Rosenberger, J. E.; Jemas, A.; Boyd, S. J.; Dmitrenko, O.; Xie, Y.; Fox, J. M. General, Divergent Platform for Diastereoselective Synthesis of trans-Cyclooctenes with High Reactivity and Favorable Physiochemical Properties**. Angew. Chem. Int. Ed. Engl. 2021, 60, 14975-14980.

(3) Murrey, H. E.; Judkins, J. C.; am Ende, C. W.; Ballard, T. E.; Fang, Y.; Riccardi, K.; Di, L.; Guilmette, E. R.; Schwartz, J. W.; Fox, J. M.; Johnson, D. S. Systematic Evaluation of Bioorthogonal Reactions in Live Cells with Clickable HaloTag Ligands: Implications for Intracellular Imaging. J. Am. Chem. Soc. 2015, 137, 11461-11475.

(4) Fang, Y.; Judkins, J. C.; Boyd, S. J.; am Ende, C. W.; Rohlfing, K.; Huang, Z.; Xie, Y.; Johnson, D. S.; Fox, J. M. Studies on the stability and stabilization of trans-cyclooctenes through radical inhibition and silver (I) metal complexation. Tetrahedron 2019, 75, 4307-4317. 